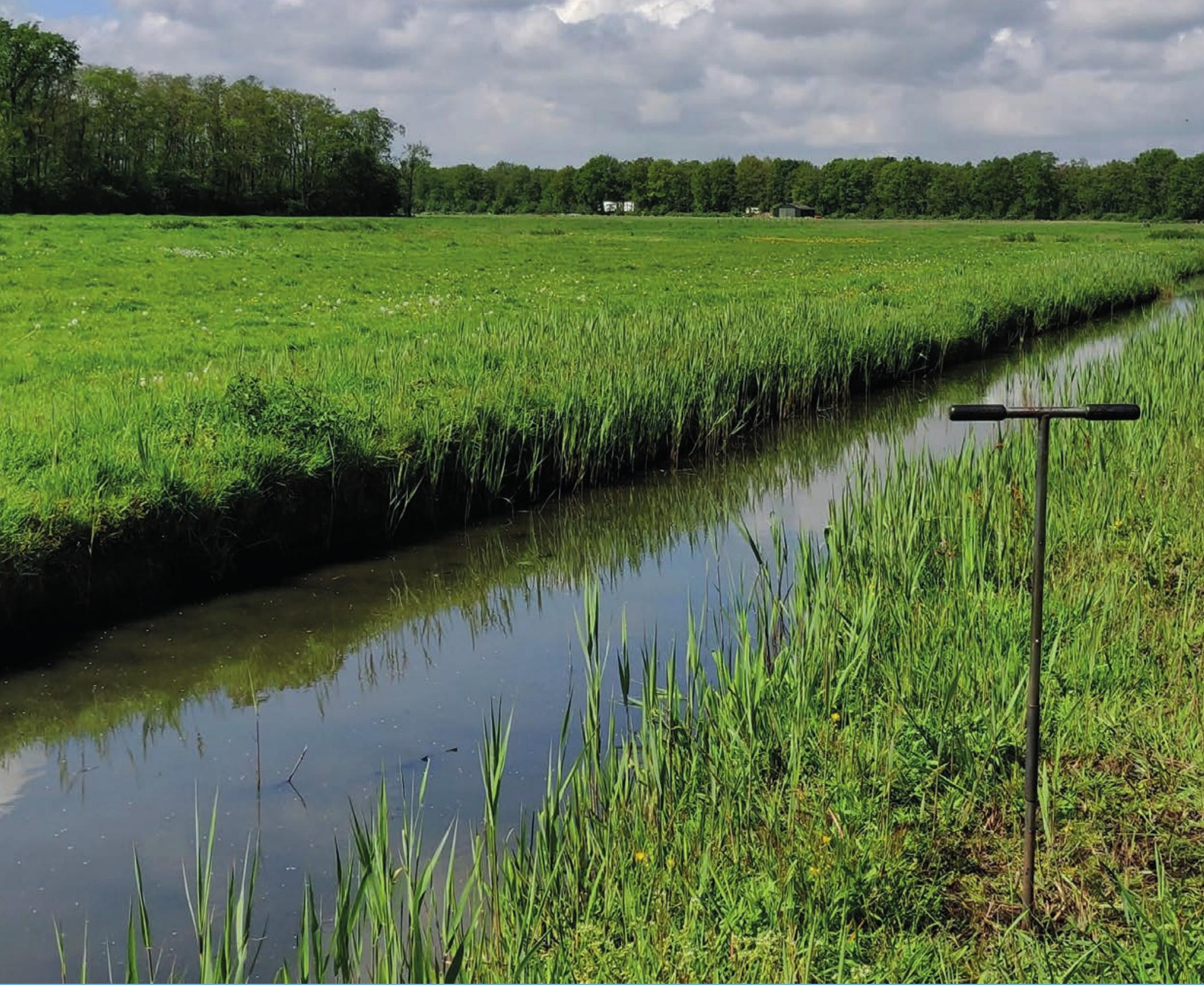

\title{
Vergelijking van twee bemonsteringsstrategieën bij toepassing van de gecombineerde indicator voor de fosfaattoestand van de bodem
}

Phillip Ehlert, Dennis Walvoort, Petra van Vliet \& Oene Oenema 



\section{Vergelijking van twee bemonsteringsstrategieën bij toepassing van de gecombineerde indicator voor de fosfaattoestand van de bodem}

Phillip Ehlert ${ }^{1}$, Dennis Walvoort ${ }^{1}$, Petra van Vliet $^{2}$ \& Oene Oenema ${ }^{1}$

1 Wageningen Environmental Research

2 Eurofins Agro B.V.

Dit onderzoek is uitgevoerd door Wageningen Environmental Research gesubsidieerd door het ministerie van Landbouw, Natuur en Voedselkwaliteit, in het kader van het Beleidsondersteunend onderzoekthema 'Mest, milieu en klimaat' (projectnummer BO-43-012.02-035).

Wageningen Environmental Research

Wageningen, mei 2021

Gereviewd door: Dr. D.J. Brus

Researcher/Lecturer Biometris, Wageningen University and Research

Akkoord voor publicatie: Dr. ir. G.J. Reinds

Teammanager Sustainable Soil Management

Rapport 3080

ISSN 1566-7197 
Ehlert, P.A.I., D.J.J. Walvoort, P.C.J. van Vliet en O. Oenema, 2021. Vergelijking van twee bemonsterings-strategieën bij toepassing van de gecombineerde indicator voor de fosfaattoestand van de bodem. Wageningen, Wageningen Environmental Research, Rapport 3080. 70 blz.; 16 fig.; 6 tab.; 11 ref.

De hoogte van de fosfaatgebruiksnorm van de Meststoffenwet is afhankelijk van de fosfaattoestand van de bodem. De fosfaattoestand op bouwland werd tot 2021 bepaald met het Pw-getal, op grasland met het P-AL-getal. In het kader van het zesde actieprogramma is nagegaan of een karakterisering van de fosfaattoestand van de bodem met de gecombineerde fosfaatindicator op basis van het $\mathrm{P}-\mathrm{CaCl}_{2}$ - en het P-AL-getal gebruikt kan worden als uitgangspunt voor de bepaling van de fosfaattoestand van de bodem. De gecombineerde indicator is per 1 januari 2021 ingevoerd.

Voor de bemonstering van de bodem ten behoeve van het aanwijzen van fosfaatarme en fosfaatfixerende landbouwpercelen is een gestratificeerde aselecte steekproef wettelijk voorgeschreven. Bij de bemonstering voor bepaling van de fosfaatklassen laag, neutraal en hoog kan het uitvoerend laboratorium het eigen, onder de accreditatie vallende, protocol toepassen. Dit bemonsteringsprotocol kan gebaseerd zijn op een in-huis-methode, zijnde de W-methode, de Z-methode (zigzag-methode) of kruislingse bemonstering.

Een verandering van de beoordeling van de fosfaattoestand van één parameter naar twee parameters heeft mogelijk invloed op het bemonsteringsprotocol voor de gestratificeerde aselecte steekproef. Contrasterende waarden voor de intensiteit en capaciteit kunnen gepaard gaan met een toename van de ruimtelijke variatie door combinatie van de twee parameters die de fosfaattoestand van de bodem karakteriseren. Een dergelijke toename heeft consequenties voor het aantal steken dat, afhankelijk van het areaal van het landbouwperceel, genomen moet worden. Er ontbrak echter informatie over de grootte van de bemonsteringsfout verbonden aan combinaties van $\mathrm{P}-\mathrm{CaCl}_{2}$ - en het P-AL-getal. Hoe het aantal steken wijzigt bij overgang naar een twee-parametersysteem, was dus niet aan te geven. Dit rapport gaat in op de vraag of de bemonsteringsstrategie aanpassing behoeft voor verschillende combinaties van het $\mathrm{P}-\mathrm{CaCl}_{2}$ - en het $\mathrm{P}$-AL-getal. Het onderzoek dient tevens beantwoording van de vraag of de bemonsteringsstrategie geharmoniseerd kan worden tot één systematiek die afdoende geborgd is en verifieerbaar is.

The phosphate application limits for grassland and arable land are outlined in the Fertilizers Act. These limits depend on the phosphate status of the soil. The phosphate status on arable land is currently determined by a water extraction ( $\mathrm{Pw}$ value), on grassland by an extraction with ammonium-lactateacetic acid (P-Al value). The sixth action program of the EU Nitrates Directive has indicated that the Ministry of Agriculture will change the methods for the characterisation of the phosphate status of the soil; a combined indicator based on the extraction with $0.01 \mathrm{M} \mathrm{CaCl}_{2}$ and $\mathrm{P}$-Al value will be used to assess the phosphate status of the soil for both grassland and arable land. This change came into effect on January $1^{\text {st }}, 2021$.

Currently, a stratified soil sampling design is required for the designation of low-phosphate and phosphate-fixing agricultural soils. For soils with higher phosphate status, accredited soil test laboratory may choose their own protocols which can be based on the W method, Z method (zigzag method) or cross sampling method. A change in the assessment of the phosphate soil status from one parameter ( $\mathrm{Pw}$ value or $\mathrm{P}-\mathrm{Al}$ value) to two parameters ( $\mathrm{P}-\mathrm{CaCl}_{2}$ value and $\mathrm{P}-\mathrm{Al}$ value) may affect the accuracy of the soil phosphate status and hence the sampling protocol. Contrasting values for the intensity and capacity may be accompanied by an increase in the spatial variability of the phosphate status of the soil. Such an increase has consequences for the number of soil cores that have be taken depending on the area of the agricultural field. However, information about the size of the sampling error associated with combinations of the $\mathrm{P}-\mathrm{CaCl}_{2}$ and $\mathrm{P}-\mathrm{Al}$ number was missing. It was therefore not possible to propose the required soil sampling protocol for the combined indicator. This report addresses the question if the sampling strategy requires adjustment for different combinations of $\mathrm{P}-\mathrm{CaCl}_{2}-$ and $\mathrm{P}-\mathrm{Al}$ values. The study also answers the question if the sampling strategy can be harmonized into one system that is adequately safeguarded and verifiable.

Trefwoorden: gestratificeerde aselecte steekproef, in-huis-methode, W-methode, gecombineerde fosfaatindicator, grondonderzoek, fosfaat, fosfaatgebruiksnorm, fosfaatklasse, bemonsteringsstrategie 
Dit rapport is gratis te downloaden van https://doi.org/10.18174/546878 of op

www.wur.nl/environmental-research (ga naar 'Wageningen Environmental Research' in de grijze balk onderaan). Wageningen Environmental Research verstrekt geen gedrukte exemplaren van rapporten.

(C) 2021 Wageningen Environmental Research (instituut binnen de rechtspersoon Stichting Wageningen Research), Postbus 47, 6700 AA Wageningen, T 03174807 00, www.wur.nl/environmental-research. Wageningen Environmental Research is onderdeel van Wageningen University \& Research.

- Overname, verveelvoudiging of openbaarmaking van deze uitgave is toegestaan mits met duidelijke bronvermelding.

- Overname, verveelvoudiging of openbaarmaking is niet toegestaan voor commerciële doeleinden en/of geldelijk gewin.

- Overname, verveelvoudiging of openbaarmaking is niet toegestaan voor die gedeelten van deze uitgave waarvan duidelijk is dat de auteursrechten liggen bij derden en/of zijn voorbehouden.

Wageningen Environmental Research aanvaardt geen aansprakelijkheid voor eventuele schade voortvloeiend uit het gebruik van de resultaten van dit onderzoek of de toepassing van de adviezen.

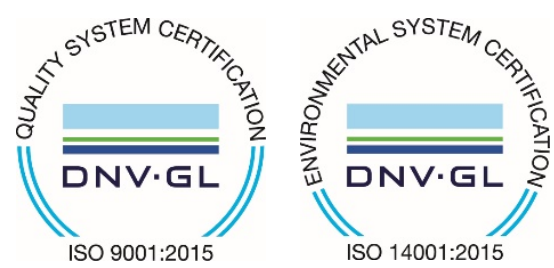

SO 14001:2015

Wageningen Environmental Research werkt sinds 2003 met een ISO 9001 gecertificeerd kwaliteitsmanagementsysteem. In 2006 heeft Wageningen Environmental Research een milieuzorgsysteem geïmplementeerd, gecertificeerd volgens de norm ISO 14001.

Wageningen Environmental Research geeft via ISO 26000 invulling aan haar maatschappelijke verantwoordelijkheid.

Wageningen Environmental Research Rapport 3080 | ISSN 1566-7197

Foto omslag: (C) Paul Gerritsen 



\section{Inhoud}

$\begin{array}{ll}\text { Verantwoording } & 7\end{array}$

$\begin{array}{ll}\text { Samenvatting } & 9\end{array}$

$\begin{array}{ll}\text { Managementsamenvatting } & 11\end{array}$

$\begin{array}{llr}1 & \text { Inleiding } & 18\end{array}$

2 Materiaal en methoden $\quad 20$

2.1 Ontwerp 20

2.2 Selectie van landbouwpercelen met contrasterende fosfaattoestanden 21

$\begin{array}{lll}2.3 & \text { Bemonsteringen van de bodem } & 22\end{array}$

2.3.1 Bemonstering gebaseerd op de gestratificeerde aselecte steekproef $\quad 22$

2.3.2 Bemonstering gebaseerd op de W-methode 22

$\begin{array}{lll}2.4 & \text { Analyses } & 23\end{array}$

2.5 Databewerking $\quad 23$

3 Gestratificeerde aselecte steekproef gebaseerd op de gecombineerde indicator

Herhaalbaarheid, reproduceerbaarheid en nauwkeurigheid van gestratificeerde aselecte steekproef en $\mathbf{W}$-methode

$\begin{array}{lll}4.1 & \text { Herhaalbaarheid } & 28\end{array}$

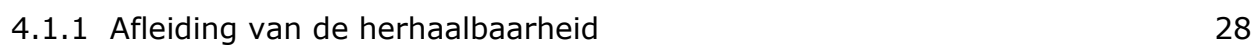

4.1.2 Toepassing van herhaalbaarheden van de twee bemonsteringsstrategieën 30

$\begin{array}{lll}4.2 & \text { Reproduceerbaarheid } & 31\end{array}$

$\begin{array}{lll}4.3 & \text { Nauwkeurigheid } & 32\end{array}$

$\begin{array}{lll}4.4 & \text { Ruimtelijke variatie } & 33\end{array}$

$5 \quad$ Bemonsteringsmethoden in de uitvoeringspraktijk 37

$6 \quad$ Evaluaties en conclusies $\quad 40$

$\begin{array}{lll}6.1 & \text { Evaluatie \& conclusies } & 40\end{array}$

$\begin{array}{lll}6.2 & \text { Aanbevelingen } & 42\end{array}$

6.2.1 Beslissen in onzekerheid $\quad 42$

$\begin{array}{ll}6.2 .2 \text { Training } & 42\end{array}$

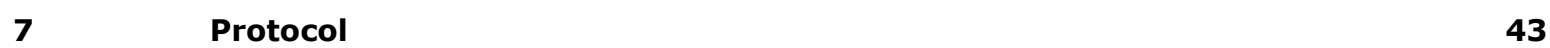

$\begin{array}{lll}7.1 & \text { Leeswijzer } & 43\end{array}$

$\begin{array}{lll}7.2 & \text { Gestratificeerde aselecte steekproef } & 43\end{array}$

$\begin{array}{ll}\text { 7.2.1 Wijzigingen } & 43\end{array}$

$\begin{array}{lll}7.3 & \text { W-methode } & 47\end{array}$

$\begin{array}{ll}\text { Literatuur } & 48\end{array}$

Bijlage 1 Berekening van het aantal steken $\quad 49$

Bijlage 2 Gelopen trajecten bij de W-methode $\quad 50$

Bijlage 3 Bubbelkaarten van de percelen voor het P-AL-getal 56

Bijlage 4 Bubbelkaarten van de percelen voor het P-CaCl${ }_{2}$-getal 62

$\begin{array}{lll}\text { Bijlage } 5 & \text { Nauwkeurigheid } & 68\end{array}$ 



\section{Verantwoording}

Rapport: 3080

Projectnummer: BO-43-012.02-035

Wageningen Environmental Research (WENR) hecht grote waarde aan de kwaliteit van zijn eindproducten. Een review van de rapporten op wetenschappelijke kwaliteit door een referent maakt standaard onderdeel uit van het kwaliteitsbeleid.

Akkoord referent die het rapport heeft beoordeeld,

functie: Researcher/Lecturer Biometris, Wageningen University and Research

naam: Dr. D.J Brus

datum: $\quad 02-03-2021$

Akkoord teamleider voor de inhoud,

naam: Dr. ir. G.J. Reinds

datum: $\quad 30-03-2021$ 


\section{Samenvatting}

De hoogte van de fosfaatgebruiksnormen voor grasland en bouwland is afhankelijk van de fosfaattoestand van de bodem. De fosfaattoestand op bouwland werd tot 2021 bepaald met het Pwgetal, op grasland met het P-AL-getal. In het kader van het zesde actieprogramma zal worden nagegaan of een karakterisering van de fosfaattoestand van de bodem met een gecombineerde fosfaatindicator op basis van het $\mathrm{P}-\mathrm{CaCl}_{2}$-getal en het $\mathrm{P}$-AL-getal gebruikt kan worden als uitgangspunt voor de bepaling van de fosfaattoestand van de bodem. De gecombineerde indicator is op 1 januari 2021 ingevoerd.

Voor de bemonstering van de bodem, voor het aanwijzen van fosfaatarme en fosfaat-fixerende landbouwpercelen, is een gestratificeerde aselecte steekproef wettelijk voorgeschreven. Bij de bemonstering voor bepaling van de fosfaatklassen laag, neutraal en hoog kan het uitvoerend laboratorium het eigen, onder de accreditatie vallende, protocol toepassen. Dit bemonsteringsprotocol kan gebaseerd zijn op de W-methode, de Z-methode (zigzag-methode) of op kruislingse bemonstering.

Een verandering van de beoordeling van de fosfaattoestand van één parameter naar twee parameters heeft mogelijk invloed op de herhaalbaarheid en reproduceerbaarheid waarmee de fosfaattoestand kan worden bepaald, en dus op het bemonsteringsprotocol voor de gestratificeerde aselecte steekproef. Contrasterende waarden voor de intensiteit (uitgedrukt in $\mathrm{P}-\mathrm{CaCl}_{2}$-waarden) en capaciteit (uitgedrukt in P-AL-getal) van het fosfaat-leverend vermogen van de bodem (uitgedrukt in de fosfaattoestand), kunnen gepaard gaan met een grotere ruimtelijke variabiliteit van de fosfaattoestand van een perceel. Een dergelijke toename heeft consequenties voor het aantal steken dat, afhankelijk van het areaal van het landbouwperceel, genomen moet worden. Er ontbrak echter informatie over de grootte van de bemonsteringsfout verbonden aan combinaties van het $\mathrm{P}-\mathrm{CaCl}_{2}$ - en $\mathrm{P}-\mathrm{AL}$-getal. Hoe het aantal steken wijzigt bij overgang naar een twee-parametersysteem, was niet aan te geven. De volgende onderzoeksdoelen zijn in deze studie genomen:

1. Het bepalen van het aantal te nemen steken bij een gestratificeerde aselecte steekproef ter bepaling van fosfaatarme of fosfaat-fixerende landpercelen, bij gebruik van een tweeparametersysteem.

2. Het bepalen van de herhaalbaarheid en reproduceerbaarheid bij een gestratificeerde aselecte steekproef en bij gebruik van de W-methode.

3. Het beoordelen van de kenmerken van de bemonsteringsmethoden t.b.v. verificatie van gerapporteerde fosfaattoestanden in het kader van handhaving door de overheid.

Deze studie geeft hierover uitsluitsel door op 43 percelen op grasland en bouwland de door de Meststoffenwet voorgeschreven gestratificeerde aselecte steekproef uit te voeren en de in de uitvoeringspraktijk meest gebruikte in-huis-methode, de W-methode, te vergelijken. Deze bemonsteringen werden in drie herhalingen uitgevoerd. Bij negen percelen werden meer strata (50) bemonsterd. De opzet van het onderzoek berustte op selectie van percelen grasland en bouwland die beantwoordden aan waarderingen voor de fosfaattoestand van laag tot hoog. Vier combinaties werden geselecteerd op basis van het P-CaCl 2 -getal en P-AL-getal, te weten laag/laag, laag/hoog, hoog/laag en hoog/hoog. Per combinatie werden vijf percelen per vorm van landgebruik geselecteerd. Door deze orthogonale opzet zouden contrasten tussen fosfaatklassen onderzocht kunnen worden. Bij herbemonstering, bij de nieuwe meetronde, werden fosfaattoestanden gemeten die afweken van de selectiecriteria, waardoor onderzoek met fosfaatklasse als factor verviel. Daardoor is onderscheid tussen bemonsteringsstrategieën per fosfaatklasse niet mogelijk. Die verschillen kunnen aanwezig zijn, maar zijn door het vervallen van de basis van het onderzoek niet te onderzoeken. Er is daarop gebruikgemaakt van statistisch observationeel onderzoek. Doordat de gemeten fosfaattoestand niet overeenkwam met die zoals beoogd volgens de selectiecriteria in paragraaf 2.2, kunnen we geen uitspraken doen over een eventuele gewenste differentiatie naar fosfaatklasse en de gevolgen daarvan voor de bemonstering. 
$\mathrm{Er}$ is meer ruimtelijke variatie op grasland vastgesteld dan op bouwland. Een hogere meetfout leidt tot een hoger aantal te nemen steken. Bemonstering van grasland vraagt meer steken dan op bouwland gegeven een totale fout. Echter, doordat wij in dit onderzoek bij de gestratificeerde steekproef een referentie-perceeloppervlakte hanteren van 5 ha en een vast aantal steken van 25, verdwijnt dit onderscheid in landgebruik.

De herhaalbaarheid en de reproduceerbaarheid van gestratificeerde aselecte steekproef en de Wmethode zijn onderling vergelijkbaar, gegeven de conditie dat de verzamelde data niet beantwoordden aan het voorgestelde orthogonale ontwerp. De systematische fout van de gestratificeerde aselecte steekproef is nul, en die van de W-methode onbekend.

Herhaling van een bemonstering op eenzelfde tijdstip leidt niet tot eenzelfde resultaat. In 9 (gestratificeerde methode) en 11 (W-methode) van de 43 percelen wordt bij herhaling een andere waarderingsklasse vastgesteld.

Voor het P-AL-getal is de nauwkeurigheid van de gestratificeerde aselecte steekproef significant $(p<0.001)$ groter dan die voor de $\mathrm{W}$-methode. Voor het $\mathrm{P}-\mathrm{CaCl}_{2}$-getal kon geen significant verschil in nauwkeurigheid tussen de methoden worden aangetoond.

Er zijn verschillen tussen de bemonsteringsmethoden in de uitvoeringspraktijk, d.w.z. de bedrijven die bodemmonsters nemen en analyseren. De gestratificeerde aselecte steekproef is wetenschappelijk onderbouwd, objectief en toepasbaar op percelen met uiteenlopende vormen en heeft een systematische fout van nul. De W-methode berust meer op praktijkervaring.

Het onderzoek is opgezet om bemonsteringsstrategieën bij contrasterende lage en hoge waarden voor het $\mathrm{P}-\mathrm{CaCl}_{2}$ - en P-AL-getal onderling te vergelijken. Bij herbemonsteringen werden de lage waarden, maar ook de hoge waarden niet meer vastgesteld. Daardoor kan geen uitsluitsel gegeven worden over het aantal te nemen steken bij fosfaat-fixerende of fosfaatarme gronden.

$\mathrm{Er}$ is zo veel ruimtelijke en temporele variatie aanwezig dat onderscheid in herhaalbaarheid en reproduceerbaarheid tussen de bemonsteringsstrategieën vervalt. Er kunnen verschillen zijn tussen deze bemonsteringsmethoden, maar deze kunnen met dit onderzoek niet worden vastgesteld. 


\section{Managementsamenvatting}

De bemesting met fosfaat in de landbouw wordt gereguleerd door de fosfaatgebruiksnormen. De fosfaatgebruiksnormen zijn gedifferentieerd naar de fosfaattoestand van de bodem en naar het landgebruik. Bij de introductie van de methode van grondonderzoek voor de bepaling van de fosfaattoestand van de bodem werd aangesloten bij de toen gangbare methoden voor grondonderzoek, te weten het Pw-getal voor bouwland en het P-AL-getal voor grasland. De bemonstering van de percelen wordt uitgevoerd door geaccrediteerde laboratoria.

Voor de vaststelling of een fosfaatarm of fosfaat-fixerend landbouwperceel in aanmerking kan komen voor een verhoogde fosfaatgebruiksnorm, werd in 2005 een protocol ontworpen, gebaseerd op een gestratificeerde aselecte steekproef. Stratificatie dient om bij bemonstering de ruimtelijke variabiliteit in het veld statistisch onderbouwd te ondervangen door een betere ruimtelijke spreiding van de steken, waardoor de fosfaattoestand nauwkeuriger kan worden berekend. Dit is nodig om nauwkeurig de fosfaattoestand van een landbouwperceel te kunnen bepalen. Tevens dient stratificatie om het aantal te nemen grondmonsters te beperken. Een onderdeel van dit protocol is het aantal steken grond dat genomen moet worden, gegeven een bepaalde nauwkeurigheidseis voor de fosfaattoestand van een perceel, en is afhankelijk van de grootte van het landbouwperceel. De variantie van de steekproeffout en de variantie van de laboratoriumfout bepalen samen de variantie van de totale fout. De totale fout bepaalt mede de grenswaarde waarbij een meetresultaat een klassegrens over- of onderschrijdt. In de huidige uitvoeringsregeling is echter geen bijzondere bepaling gewijd aan de grenswaarde, maar wel wordt het aantal te nemen steken voorgeschreven (uitvoeringsregeling Meststoffenwet, Bijlage C). De laboratoriumanalyse wordt uitgevoerd in duplo.

Voor de bemonstering van landbouwpercelen met andere fosfaatwaarderingen (laag, neutraal, hoog) mag een geaccrediteerd laboratorium een in-huis-methode toepassen (uitvoeringsregeling Meststoffenwet, Bijlage L). Laboratoria gebruiken de W-methode, de zigzag-methode of kruislingse bemonstering. Van een perceel met een maximale grootte van 5 ha wordt één representatief grondmonster gestoken. Dit monster bestaat uit veertig submonsters van gelijke omvang. De veertig submonsters worden samengevoegd tot één monster per perceel, dat wordt geanalyseerd. Om voldoende grond te verzamelen, wordt eventueel tweemaal een monster gestoken om de minimale hoeveelheid grond te verzamelen, mits dit dan op alle bemonsteringspunten gebeurt. Bemestingsvrije zones worden gemeden. Aan elkaar grenzende percelen mogen worden samengevoegd tot een totale omvang van ten hoogste 5 ha. De omvang van een individueel perceel mag dan niet groter zijn dan 2,5 ha.

Voor grasland is de bemonsteringsdiepte $10 \mathrm{~cm}$, voor bouwland $25 \mathrm{~cm}$. Bij de bemonstering worden meststofresten gemeden.

Sinds 2004 wordt in de landbouwpraktijk de fosfaattoestand veelal bepaald op basis van een combinatie van een intensiteitsparameter $\left(\mathrm{P}-\mathrm{CaCl}_{2}\right)$ en een capaciteitsparameter ( $\mathrm{P}$-AL-getal). Aanvankelijk werd deze combinatie van parameters toegepast om daaruit het Pw-getal te berekenen (om laboratorium-technische redenen). Sinds 2011 wordt deze combinatie direct toegepast bij bemestingsadvisering op basis van grondonderzoek voor snijmais en vanaf 2012 bij grasland ( $1^{\mathrm{e}}$ snede). Voor vollegrondsteelten is een bemestingsadvies op basis van deze combinatie in ontwikkeling. Door overnames van laboratoria en wijzigingen in hun uitvoeringspraktijk is in Nederland een daadwerkelijke meting van het Pw-getal van bouwland door laboratoria vrijwel verdwenen.

Een overzicht voor 2019 opgesteld door CBS (2020) wijst uit dat 34\% van het aantal graslandpercelen en $45 \%$ van het aantal bouwlandpercelen geen meting hebben van de fosfaattoestand. Deze percelen hebben daardoor de fosfaattoestand hoog toegewezen gekregen (defaultwaarde als geen metingen beschikbaar zijn). Percelen met de fosfaattoestand arm vertegenwoordigen in de populatie van gemeten fosfaattoestanden op grasland $5,7 \%$ en op bouwland $17,1 \%$ van de metingen. 
De beleidsbeslissing ${ }^{1}$ van het ministerie van LNV is om in het kader van het zesde actieprogramma Nitraatrichtlijn vanaf 1 januari 2021 de combinatie van het P-AL-getal en het $\mathrm{P}-\mathrm{CaCl}_{2}$-getal - een gecombineerde indicator - te gebruiken voor het bepalen van de fosfaatgebruiksnorm van een bepaald perceel. Deze wijziging heeft drie mogelijke gevolgen voor de bepalingen voor fosfaatgebruiksnormen van de Meststoffenwet. De wijziging:

1. heeft een mogelijk effect op de bemonsteringsfout en derhalve op het protocol voor de bemonstering van de bodem,

2. verschuift mogelijk de klasse-indeling van de fosfaattoestand en

3. leidt mede daardoor tot een mogelijke aanpassing van de hoogte van de fosfaatgebruiksnorm gegeven een klasse-indeling.

Dit onderzoek gaat in op consequenties van de overgang naar een twee-parametersystem voor het protocol voor de bemonstering van de bodem.

Een verandering van de beoordeling van de fosfaattoestand van één parameter naar twee parameters heeft mogelijk invloed op het bemonsteringsprotocol voor de gestratificeerde aselecte steekproef. Contrasterende waarden voor de intensiteit en capaciteit kunnen gepaard gaan met een toename van de bemonsteringsfout en dat heeft mogelijk consequenties voor het aantal steken dat, afhankelijk van het areaal van het landbouwperceel, genomen moet worden. Er ontbrak echter informatie over de bemonsteringsfout verbonden aan combinaties van $\mathrm{P}-\mathrm{CaCl}_{2}$-getal en $\mathrm{P}$-AL-getal om de gevolgen voor het bemonsteringsprotocol aan te kunnen geven.

In de uitvoeringspraktijk wordt de gestratificeerde aselecte steekproef meestal niet toegepast (de Meststoffenwet schrijft die methode voor enkel voor het aanwijzen van P-arme en P-fixerende gronden). In plaats daarvan worden de W-methode (meest gebruikt), Z-methode (zigzagmethode) en de kruislingse bemonsteringsmethoden gebruikt. In deze studie is in goed overleg met het ministerie van LNV de W-methode betrokken. De prestatiekenmerken qua herhaalbaarheid of reproduceerbaarheid van deze bemonsteringsmethoden zijn niet bekend voor de gecombineerde indicator. Herhaalbaarheid en reproduceerbaarheid zijn kenmerken voor precisie. Bij handhaving is reproduceerbaarheid een belangrijke indicator (en criterium). Een eventuele systematische fout komt echter niet tot uitdrukking in herhaalbaarheid. Een grote systematische fout kan gepaard gaan met een zeer goede herhaalbaarheid. De systematische fout vergt nadere aandacht. Bij herbemonstering, die verificatie dient van een eerder door meting vastgestelde fosfaattoestand, is een criterium nodig om tot acceptatie van het nieuwe onderzoeksresultaat te komen of tot verwerping ervan. In dit kader is kennis over de reproduceerbaarheid en de nauwkeurigheid met de systematische fout nodig.

Dit onderzoek dient om een bemonsteringsprotocol voor het toetsen van de fosfaattoestand van de bodem - t.b.v. het aanwijzen van een fosfaatgebruiksnorm - aan te passen aan een tweeparametersysteem (de gecombineerde indicator) voor het meten van de fosfaattoestand van de bodem. Daartoe zijn de volgende onderzoeksdoelen in studie genomen:

1. Het bepalen van het aantal te nemen steken bij een gestratificeerde aselecte steekproef ter bepaling van fosfaatarme of fosfaat-fixerende landpercelen bij gebruik van een tweeparametersysteem.

2. Het bepalen van de herhaalbaarheid en reproduceerbaarheid bij een gestratificeerde aselecte steekproef en bij gebruik van de W-methode.

3. Het beoordelen van de kenmerken van de bemonsteringsmethoden, t.b.v. verificatie van gerapporteerde fosfaattoestanden in het kader van handhaving door de overheid.

Om aan deze doelen te kunnen beantwoorden, werden drie bemonsteringsstrategieën uitgevoerd op geselecteerde landbouwpercelen op grasland en bouwland. Bij de selectie door Eurofins Agro zijn landbouwpercelen getraceerd die beantwoorden aan contrasterende waarden voor het $\mathrm{P}-\mathrm{CaCl}_{2}-\mathrm{getal}$ en het P-AL-getal. Vier 'extremen' in fosfaattoestanden per vorm van landgebruik gemeten als $\mathrm{P}$ $\mathrm{CaCl}_{2}$-getal en P-AL-getal werden opgelegd, die samen de combinaties laag/laag, laag/hoog, hoog/laag en hoog/hoog vormden (Tabel MS 1). Per combinatie werden vijf herhalingen opgenomen, wat resulteerde in twintig graslandpercelen en twintig bouwlandpercelen. Initieel opgelegde criteria

\footnotetext{
1 Staatscourant 2019 nr. 41931, 25 juli 2019
} 
moesten worden verruimd omdat er niet voldoende percelen konden beantwoorden aan de opgelegde eisen. Ook bleek herhaling van bemonstering nodig in drie situaties. Daardoor is het aantal bemonsterde percelen drieënveertig. Op grasland werd de bodemlaag 0-10 cm bemonsterd; op bouwland de bodemlaag 0-25 cm, conform de bepalingen van de uitvoeringsregeling Meststoffenwet (Bijlage $\mathrm{C}$ en Bijlage $\mathrm{L}$ ). In de grondmonsters werden nat-chemisch het $\mathrm{P}-\mathrm{CaCl}_{2}$-getal en $\mathrm{P}$-AL-getal bepaald.

Tabel MS 1 Initieel opgelegde criteria voor toestanden laag en hoog naar Oenema et al. (2016) en na aanpassing i.v.m. verruiming van de selectie.

\begin{tabular}{|c|c|c|c|c|}
\hline \multirow[b]{2}{*}{ Waardering } & \multicolumn{2}{|l|}{ Initieel } & \multicolumn{2}{|l|}{ Aangepast } \\
\hline & $\begin{array}{l}\mathrm{P} \text {-CaCl} 2 \text {-getal, } \\
\mathrm{mg} \mathrm{P/kg}\end{array}$ & $\begin{array}{l}\text { P-AL-getal, } \\
\text { mg } \mathrm{P}_{2} \mathrm{O}_{5} / 100 \mathrm{~g}\end{array}$ & $\begin{array}{l}\mathrm{P} \text {-CaCl} 2 \text {-getal, } \\
\mathrm{mg} \mathrm{P/kg}\end{array}$ & $\begin{array}{l}\text { P-AL-getal, } \\
\text { mg } \mathrm{P}_{2} \mathrm{O}_{5} / 100 \mathrm{~g}\end{array}$ \\
\hline Hoog & $>4,0$ & $>60$ & $>4,0$ & $>50$ \\
\hline
\end{tabular}

Met de aangepaste klasse-indeling werden de landbouwpercelen geselecteerd, bemonsterd en vervolgens werden de grondmonsters geanalyseerd op $\mathrm{P}-\mathrm{CaCl}_{2}$-getal en $\mathrm{P}$-AL-getal. De uitkomst leerde dat er analyseresultaten waren met fosfaattoestanden die tussen de beoogde indeling van laag en hoog vielen. In het kader van deze studie worden die fosfaattoestanden met 'matig' aangeduid. De gemeten waarden voor de combinaties laag/laag, laag/hoog, hoog/laag en hoog/hoog kwamen niet overeen met die van de selectiecriteria. Voor de analyse betekende dit dat een orthogonale ANOVAanalyse met fosfaatklasse als factor uitgesloten werd. Hierdoor ontbreekt uitsluitsel of een bemonsteringsstrategie afhankelijk is van een fosfaatklasse. Bij herbemonstering en analyse een jaar later werden fosfaat-fixerende of fosfaatarme gronden niet meer vastgesteld ondanks opgelegde selectiecriteria. Voor een specifieke aanpassing van het protocol voor bemonstering gebaseerd op de gestratificeerde aselecte steekproef is daardoor geen resultaat beschikbaar om een wijziging voor te stellen strikt gefocust op deze fosfaatklasse.

Als alternatief is een statistisch observationele analyse uitgevoerd op basis van bemonsteringsmethode en percelen. Er was veel variatie in de data aanwezig, hetgeen de vergelijking van de bemonsteringsmethoden verzwakt.

\section{Aantal steken bij een gestratificeerde aselecte steekproef ter bepaling van een fosfaatarme of fosfaat-fixerend landperceel op basis van de gecombineerde indicator of twee-parametersysteem}

Het aantal steken is afhankelijk van de totale fout die verbonden is aan bemonstering en aan analyse.

In deze studie wordt aangesloten bij de systematiek die nu geldt bij uitvoering van de gestratificeerde aselecte steekproef voorgeschreven door de Meststoffenwet voor fosfaatarme en -fixerende gronden (uitvoeringsregeling Meststoffenwet, Bijlage C). Dat wil zeggen dat het aantal strata per landbouwperceel afhankelijk is van de grootte van het areaal. Er wordt nu in de Uitvoeringsregeling Meststoffenwet geen onderscheid aangebracht naar landgebruik. Concreet wordt per stratum een grondmonster genomen. Uit de per stratum genomen grondmonsters wordt een mengmonster samengesteld. Het mengmonster wordt vervolgens in duplo geanalyseerd. Dit is als uitgangspunt genomen voor het bepalen van het aantal steken.

In 2005 zijn landbouwpercelen met een lage fosfaattoestand geselecteerd. Bij lage fosfaattoestanden is de meetfout in absolute zin laag. ${ }^{2}$ In de huidige studie zijn percelen met onderscheidenlijke lage en hoge fosfaattoestanden geselecteerd. Daardoor zijn gegevens aanwezig van fosfaattoestanden met hoge waarden waarbij de meetfout in absolute zin hoger is. Een hogere meetfout leidt tot een hoger aantal te nemen steken. Bij herbemonstering werden de beoogde contrasterende fosfaattoestanden

2 Prestatiekenmerken bij analyses van fosfaat in grondmonsters zijn afhankelijk van de hoogte van de fosfaattoestand (Ehlert et al., 2007). De binnenlaboratorium-reproduceerbaarheid van $\mathrm{P}-\mathrm{CaCl}_{2}-$ getal is bij $<2,2-8$ en $>8 \mathrm{mg} \mathrm{P} / \mathrm{kg}$ respectievelijk 0,5 mg P/kg, 0,8 mg P/kg en 10\%. Bij P-AL-getal bij waarden $<50,50-80$ en $>80 \mathrm{mg} \mathrm{P}_{2} \mathrm{O}_{5} / 100 \mathrm{~g}$ respectievelijk 6 en $8 \mathrm{mg} \mathrm{P} \mathrm{P}_{2} \mathrm{O}_{5} / 100 \mathrm{~g}$ en $10 \%$. 
met waarderingen laag en hoog niet meer vastgesteld. De beoogde proefopzet met contrasten in fosfaattoestand met een statistisch orthogonale opzet verviel. Dit belemmert duiding van de betekenis van invoering van de gecombineerde indicator voor fosfaat-fixerende en fosfaatarme gronden. De resultaten in deze managementsamenvatting zijn gebaseerd op een statistische analyse, waarbij geen onderscheid naar fosfaatklasse aangebracht kon worden.

De huidige resultaten bevestigen de resultaten van het onderzoek uit 2005 dat het aantal steken niet evenredig toeneemt met de grootte van het areaal landbouwperceel (Tabel MS 2). Indien een landbouwperceel van 10 ha naar 20 ha vergroot, neemt het aantal te nemen steken toe van 29 naar 33 steken bij de bemonstering voor P-AL-getal en van 28 naar 31 voor $\mathrm{P}-\mathrm{CaCl}_{2}$. Deze aantallen gelden voor een nauwkeurigheidseis van 2,0 en 2,5 mg $\mathrm{P}_{2} \mathrm{O}_{5} / 100 \mathrm{~g}$ voor P-AL-getal voor respectievelijk bouwland en grasland en 0,12 en $0,47 \mathrm{mg} \mathrm{P} / \mathrm{kg}$ voor $\mathrm{P}-\mathrm{CaCl}_{2}$-getal voor respectievelijk bouw- en grasland. Deze aantallen zijn hoger dan in 2005, omdat toen landbouwpercelen met een lage fosfaattoestand werden geselecteerd, waardoor minder variatie in fosfaattoestand aanwezig is. De data van de huidige studie zijn afkomstig van percelen die niet aangemerkt kunnen worden als fosfaat-fixerend of fosfaatarm en variëren meer tussen laag en hoog.

De totale fout, bepaald door de steekproeffout en de analysefout, neemt af indien het aantal steken hoger wordt. Bij lage aantallen steken $(<20)$ is deze fout hoog. De precisie neemt toe door meer steken te nemen. In deze studie is gekozen voor een totale fout gebaseerd op 25 steken voor een referentieperceelgrootte van $5 \mathrm{ha}$, bij hogere aantallen steken neemt deze fout nauwelijks af, bij lagere aantallen neemt deze fout fors toe.

Bij grasland zijn bij toepassing van de gestratificeerde steekproef meer steken nodig om tot eenzelfde totale fout te komen dan op bouwland. Wij veronderstellen dat dit verschil veroorzaakt wordt door het ontbreken van een jaarlijkse kerende grondbewerking op grasland, zoals dat op de meeste bouwlandpercelen wel het geval is. Echter, doordat wij een referentieperceeloppervlakte hanteren verdwijnt dit onderscheid in landgebruik.

\section{Samenvattend}

Het onderzoek is opgezet om bemonsteringsstrategieën bij contrasterende lage en hoge waarden voor $\mathrm{P}-\mathrm{CaCl}_{2}$ - en $\mathrm{P}$-AL-getal onderling te vergelijken. Bij herbemonsteringen werden de lage waarden, maar ook de hoge niet meer vastgesteld. Daardoor kan geen uitsluitsel gegeven worden over het aantal te nemen steken bij fosfaat-fixerende of fosfaatarme gronden.

Los van een indeling in een fosfaatklasse wijst de studie uit dat vergelijkbare aantal steken per perceel nodig zijn voor de bepaling van het $\mathrm{P}-\mathrm{CaCl}_{2}$-getal en het $\mathrm{P}$-AL-getal. Het aantal steken neemt toe met de grootte van het areaal. Het aantal steken op grasland is hoger dan op bouwland, omdat op de graslandpercelen meer ruimtelijke variatie werd vastgesteld. 
Tabel MS 2 Berekend minimaal aantal benodigde steken per perceel om onder een grenswaarde uit te komen voor P-AL-getal en $\mathrm{P}$ - $\mathrm{CaCl}_{2}$-getal voor bouwland en grasland, gegeven dat er één mengmonster wordt samengesteld en in duplo wordt geanalyseerd.

\begin{tabular}{|c|c|c|c|c|}
\hline \multirow{3}{*}{$\begin{array}{l}\text { Oppervlakte perceel } \\
\text { ha }\end{array}$} & \multicolumn{2}{|l|}{ P-AL-getal } & \multicolumn{2}{|l|}{ P-CaCl${ }_{2}$-getal } \\
\hline & Bouwland & Grasland & Bouwland & \\
\hline & $2,0 \mathrm{mg} \mathrm{P}_{2} \mathrm{O}_{5} / 100 \mathrm{~g}$ & $2,5 \mathrm{mg} \mathrm{P}_{2} \mathrm{O}_{5} / 100 \mathrm{~g}$ & $0,12 \mathrm{mg} P / \mathrm{kg}$ & $0,47 \mathrm{mg} P / \mathrm{kg}$ \\
\hline 2 & 22 & 21 & 22 & 21 \\
\hline 3 & 23 & 23 & 23 & 23 \\
\hline 5 & 25 & 25 & 25 & 25 \\
\hline 6 & 26 & 26 & 26 & 26 \\
\hline 7 & 26 & 27 & 26 & 26 \\
\hline 8 & 27 & 27 & 27 & 27 \\
\hline 30 & 34 & 35 & 34 & 32 \\
\hline 40 & 35 & 37 & 36 & 33 \\
\hline 50 & 37 & 38 & 37 & 33 \\
\hline
\end{tabular}

\section{Vergelijking van de herhaalbaarheid en reproduceerbaarheid van de gestratificeerde aselecte steekproef en de $\mathbf{W}$-methode}

Om de vergelijking tussen een gestratificeerde aselecte steekproef en de W-methode te kunnen maken, onderscheiden wij herhaalbaarheid, reproduceerbaarheid en nauwkeurigheid.

Herhaalbaarheid wordt in deze studie omschreven als 'de mate van overeenstemming tussen de resultaten van opeenvolgende metingen van dezelfde meetgrootheid, die onder identieke meetomstandigheden zijn verricht'.

Reproduceerbaarheid wordt omschreven als 'de mate van overeenstemming tussen de meetresultaten van dezelfde meetgrootheid, verkregen onder wisselende meetomstandigheden. De wisselende omstandigheden kunnen omvatten: de waarnemer, het meetinstrument, de plaats binnen het perceel en de tijd, dat wil zeggen een periode kort genoeg, zodat nauwelijks veranderingen zijn te verwachten in de fosfaattoestand'.

Nauwkeurigheid wordt omschreven als 'de mate van overeenstemming van een gemeten of bekende waarde met zijn daadwerkelijke waarde'.

Zowel de gestratificeerde aselecte steekproef als de W-methode werd met drie herhalingen uitgevoerd. In generieke zin, dat wil zeggen uitmiddelend over alle waarnemingen, blijken beide methoden tot een vergelijkbare uitkomst te leiden. Er zijn geen statistisch significante verschillen vastgesteld tussen de bemonsteringsmethoden.

De drie herhalingen zijn per bemonsteringsstrategie gebruikt om vast te stellen of telkens eenzelfde plaatsing in een fosfaatklasse wordt vastgesteld. Dit betreft een bemonstering op eenzelfde tijdstip (herhaalbaarheid). Daarnaast kan onderzocht worden of een rubricering in een fosfaatklasse waarmee een landbouwperceel werd geselecteerd, teruggevonden wordt bij een volgende bemonstering die doorgaans een jaar later werd uitgevoerd. Dit betreft de vergelijking van de selectie van landbouwpercelen op basis van bekende grondanalyses met de analyseresultaten die bij herbemonstering werden vastgesteld (reproduceerbaarheid).

In totaal werden dezelfde 43 percelen bemonsterd volgens de gestratificeerde methode en volgens de W-methode. Voor de gestratificeerde methode waren voor 34 percelen de klassen voor de herhalingen identiek en voor 9 percelen verschillend. Voor de W-methode waren voor 32 percelen de klassen voor de herhalingen identiek en voor 11 percelen verschillend. 
We konden geen verschillen aantonen tussen de gestratificeerde aselecte steekproef en de W-methode wat betreft herhaalbaarheid en reproduceerbaarheid. Hieraan draagt mede het feit bij dat de verzamelde gegevens niet beantwoordden aan het voorgestelde orthogonale ontwerp.

Voor het P-AL-getal vonden we een significant $(\mathrm{p}<0.001)$ hogere nauwkeurigheid dan voor de $\mathrm{W}$ methode. Voor het $\mathrm{P}-\mathrm{CaCl}_{2}$-getal kon geen significant verschil in nauwkeurigheid worden aangetoond tussen de twee methoden. Hierbij moet worden aangetekend dat voor de W-methode ca. twee keer zoveel steken zijn genomen als voor de gestratificeerde aselecte steekproef en worden delen van het landbouwperceel systematisch niet betrokken bij de bemonstering. Zouden die aantallen meer vergelijkbaar zijn, dan verwachten we op basis van deze resultaten grotere verschillen in nauwkeurigheid.

Doordat bij herbemonstering de vastgestelde fosfaattoestand niet overeenkwam met die zoals beoogd volgens de selectiecriteria (zie paragraaf 2.2) kunnen we geen uitspraken over een eventuele gewenste differentiatie van het aantal steken per perceel naar fosfaatklasse en de gevolgen daarvan voor de bemonstering.

\section{Samenvattend}

Doordat bij herbemonstering de vastgestelde fosfaattoestand niet overeenkwam met die zoals beoogd volgens de selectiecriteria (zie paragraaf 2.2) kunnen we geen uitspraken over een eventuele gewenste differentiatie van het aantal steken per perceel naar fosfaatklasse. In generieke zin, dat wil zeggen uitgemiddeld over 43 percelen, geven de gestratificeerde aselecte steekproef-

bemonsteringsmethode en de $\mathrm{W}$-bemonsteringsmethode vergelijkbare resultaten met betrekking tot de herhaalbaarheid en reproduceerbaarheid van de bepaling van de fosfaattoestand. Dit impliceert dat er vanuit het oogpunt van de herhaalbaarheid en reproduceerbaarheid van de bepalingsmethoden geen noodzaak is om de bemonsteringsmethoden aan te passen.

\section{Beoordeling van de kenmerken van de bemonsteringsmethoden}

Er zijn verschillen tussen de bemonsteringsmethoden die in de uitvoeringspraktijk worden toegepast. De bemonsteringsmethode, waarbij een gestratificeerde aselecte steekproef werkwijze wordt toegepast, is wetenschappelijk onderbouwd, objectief en toepasbaar op percelen met uiteenlopende vormen, de W-methode berust meer op praktijkervaring. Tabel MS 3 geeft een overzicht van de kenmerken van de bemonsteringsmethoden.

Tabel MS 3 Kenmerken van de bemonsteringsmethoden bij gebruik van een gestratificeerde aselecte steekproef en de $W$-methode voor het selecteren van bemonsteringslocaties in een perceel.

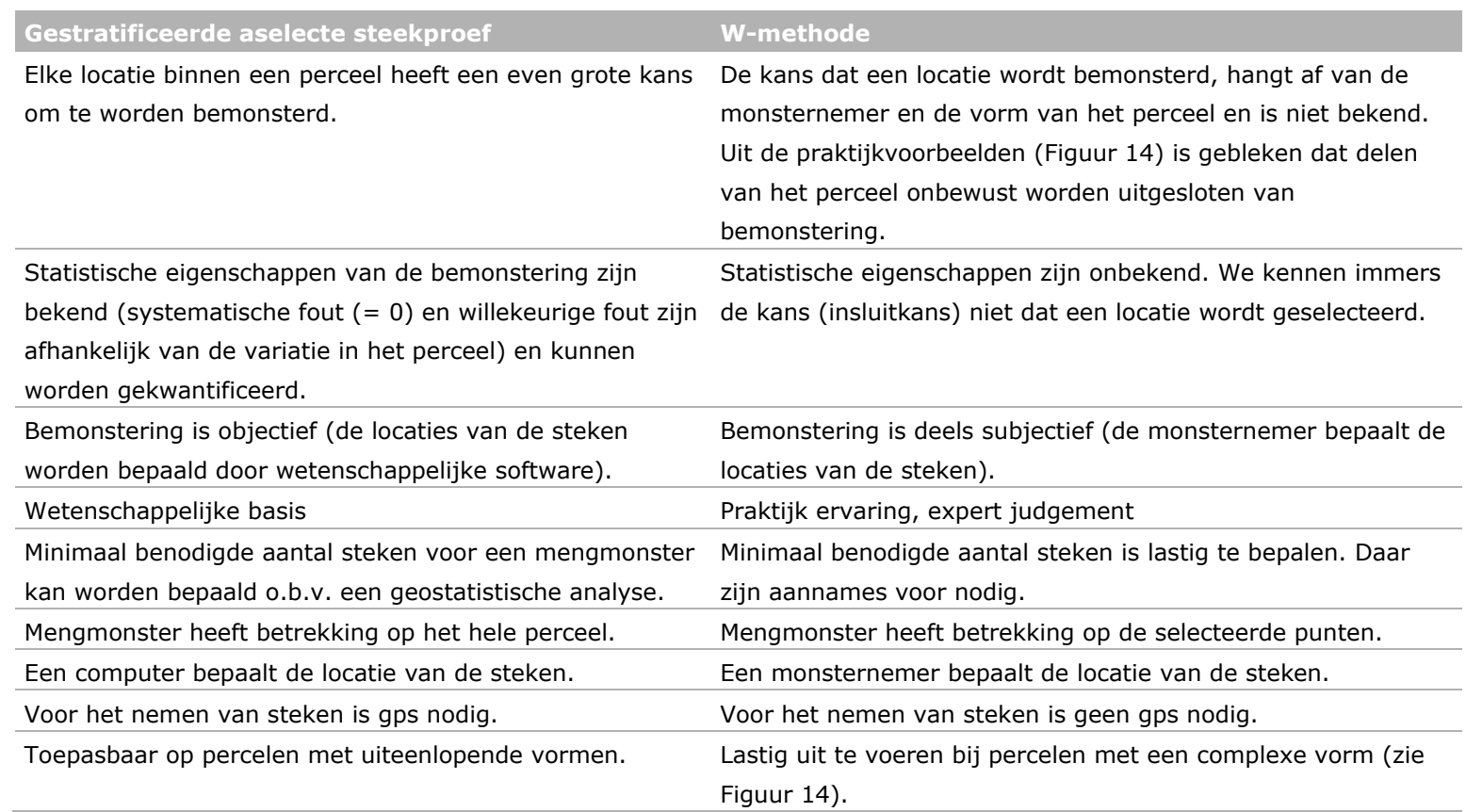




\section{Samenvattend}

$\mathrm{Er}$ is een groot aantal verschillen in de kenmerken van de twee vergeleken bemonsteringsmethoden. De bemonstering van een perceel op basis van een gestratificeerde aselecte steekproef leidt tot een statistisch verantwoord en juist analyseresultaat, maar vergt mogelijk meer bemonsteringstijd. De bemonstering van een perceel op basis van de W-bemonsteringsmethode is gebaseerd op jarenlange praktijkervaring, is eenvoudig toe te passen, maar bevat een element van subjectiviteit. De herhaalbaarheid en reproduceerbaarheid van de bepaling van de fosfaattoestand van monsters verkregen via de gestratificeerde aselecte steekproef en de W-methode waren echter vergelijkbaar. Dit resultaat werd verkregen voor 43 landbouwpercelen met dominant matige fosfaattoestanden, dat wil zeggen tussen de waarderingen laag en hoog in. 


\section{$1 \quad$ Inleiding}

De fosfaatbemesting in de landbouw wordt gereguleerd door de fosfaatgebruiksnormen. De fosfaatgebruiksnormen zijn gedifferentieerd naar de fosfaattoestand van de bodem en naar het landgebruik. Bij de introductie van de methoden van grondonderzoek voor de bepaling van de fosfaattoestand van de bodem in 2006 werd door de Directie Landbouw van het toenmalige ministerie voor Landbouw, Natuur en Voedselveiligheid aangesloten bij de toen gangbare methoden voor grondonderzoek, te weten het Pw-getal voor bouwland en het P-AL-getal voor grasland. De bemonstering van de percelen wordt uitgevoerd door geaccrediteerde laboratoria, die 40 submonsters van een perceel nemen door volgens een in-huis-bemonsteringsprotocol, gebaseerd op een $\mathrm{W}$-methode, Z-methode (zigzag-methode) of kruislingse methode, over een perceel van maximaal 5 ha te gaan. De veertig submonsters van elk een gelijk volume worden samengevoegd tot één monster per perceel, dat wordt geanalyseerd.

Voor de vaststelling of een fosfaatarm of fosfaat-fixerend landbouwperceel in aanmerking kan komen voor een verhoogde fosfaatgebruiksnorm, werd in 2005 een protocol ontworpen gebaseerd op een gestratificeerde aselecte steekproef (Ehlert et al., 2005). Stratificatie dient om bij bemonstering de ruimtelijke variabiliteit in het veld statistisch onderbouwd te ondervangen. Dit dient het verkrijgen van een representatief grondmonster van het desbetreffende landbouwperceel en daarmee de nauwkeurigheid van de vaststelling van de fosfaattoestand. Tevens dient stratificatie om het aantal te nemen grondmonsters te beperken. Een onderdeel van dit protocol is het aantal steken grond dat genomen moet worden, gegeven een bepaalde nauwkeurigheidseis voor de fosfaattoestand van een perceel. Het aantal steken is afhankelijk van de grootte van het landbouwperceel. De variantie van de steekproeffout en de variantie van de laboratorium-analysefout bepalen samen de variantie van de totale fout (Ehlert et al., 2005). De totale fout bepaalt een over- of onderschrijding van een klassegrens. In de huidige uitvoeringsregeling is echter geen bijzondere bepaling gewijd aan de grenswaarde voor de totale toegelaten fout, maar wel wordt het aantal te nemen steken voorgeschreven (uitvoeringsregeling Meststoffenwet, Bijlage $\mathrm{C}$ ). De bepaling van de fosfaattoestand van het grondmonster wordt door laboratoria in duplo uitgevoerd.

Sinds 2004 wordt in de landbouwpraktijk de fosfaattoestand bepaald op basis van een combinatie van een intensiteitsparameter $\left(\mathrm{P}-\mathrm{CaCl}_{2}\right)$ en capaciteitsparameter ( $\mathrm{P}-\mathrm{AL}$-getal). Aanvankelijk werd deze combinatie van parameters toegepast om daaruit het $\mathrm{Pw}$-getal te berekenen (om laboratoriumtechnische redenen). Sinds 2011 wordt deze combinatie direct toegepast bij bemestingsadvisering op basis van grondonderzoek voor snijmais en vanaf 2012 bij grasland ( $1^{\mathrm{e}}$ snede). Voor vollegrondsteelten is een bemestingsadvies op basis van deze combinatie in ontwikkeling. Door overnames van laboratoria en wijzigingen in hun uitvoeringspraktijk is in Nederland een daadwerkelijke meting van het Pw-getal door laboratoria vrijwel verdwenen.

De beleidsbeslissing ${ }^{3}$ is om in het kader van het zesde actieprogramma Nitraatrichtlijn in 2021, de combinatie van het P-AL-getal en het $\mathrm{P}-\mathrm{CaCl}_{2}$-getal te gebruiken als basis voor het bepalen van de fosfaattoestand van de bodem, ten behoeve van het afleiden van de fosfaatgebruiksnorm van een bepaald perceel. De gecombineerde indicator is per 1 januari 2021 ingevoerd. Deze wijziging heeft drie mogelijke gevolgen voor de bepalingen voor fosfaatgebruiksnormen van de Meststoffenwet. Wijziging:

1. heeft een mogelijk effect op de bemonsteringsfout en derhalve op het protocol voor de bemonstering van de bodem,

2. verschuift mogelijk de klasse-indeling van de fosfaattoestand en

3. leidt mede daardoor tot een mogelijke aanpassing van de hoogte van de fosfaatgebruiksnorm gegeven een klasse-indeling.

Dit onderzoek gaat in op consequenties van de overgang naar een twee-parametersystem voor het protocol voor de bemonstering van de bodem.

\footnotetext{
3 Staatscourant 2019 nr. 41931, 25 juli 2019
} 
Een protocol voor de bemonstering van de bodem dient ter ondervanging van de ruimtelijke variabiliteit die altijd aanwezig is in een landbouwperceel. Een verandering van de beoordeling van de fosfaattoestand van één parameter naar twee parameters heeft mogelijk invloed op het bemonsteringsprotocol voor de gestratificeerde aselecte steekproef. Contrasterende waarden voor de intensiteit en capaciteit kunnen gepaard gaan met een toename van de ruimtelijke variabiliteit van de fosfaattoestand van de bodem. Een dergelijke toename heeft consequenties voor het aantal steken dat, afhankelijk van het areaal van het landbouwperceel, genomen moet worden. Er ontbreekt echter informatie over de bemonsteringsfout verbonden aan combinaties van het $\mathrm{P}-\mathrm{CaCl}_{2}$ - en $\mathrm{P}$-AL-getal om de gevolgen voor het bemonsteringsprotocol aan te kunnen geven.

Er is eerst verkend of na 2005 onderzoek is uitgevoerd naar effecten van ruimtelijke variabiliteit van landbouwpercelen op het aantal te nemen steken bij toepassing van het twee-paramatersysteem. Noch bij Eurofins Agro, noch bij Alterra (thans Wageningen Environmental Research) zijn meetgegevens beschikbaar waaruit afgeleiden (semivariogram) van ruimtelijke variabiliteit voor verschillende combinaties van het $\mathrm{P}-\mathrm{CaCl}_{2}$ - en $\mathrm{P}$-AL-getal zijn te berekenen. Een mogelijkheid om het aantal te nemen steken per areaal landbouwperceel te bepalen, ontbreekt daardoor.

In de uitvoeringspraktijk wordt de gestratificeerde aselecte steekproef meestal niet toegepast (de Meststoffenwet schrijft deze bemonsteringsmethode enkel voor in geval sprake is van P-arme en Pfixerende gronden). In plaats daarvan worden de W-methode (meest gebruikt), Z-methode (zigzagmethode) en de kruislingse bemonsteringsmethode gebruikt. De prestatiekenmerken qua herhaalbaarheid of reproduceerbaarheid van deze bemonsteringsmethoden zijn niet bekend. Herhaalbaarheid en reproduceerbaarheid zijn kenmerken voor precisie. Bij handhaving is reproduceerbaarheid een belangrijke indicator (en criterium). Bij herbemonstering, die ter verificatie dient van een eerder door meting vastgestelde fosfaattoestand, is een criterium nodig om tot acceptatie van het nieuwe onderzoeksresultaat te komen of tot verwerping ervan. In dit kader is kennis over de herhaalbaarheid, reproduceerbaarheid en systematische fout nodig.

In 2010 waren verschillende laboratoria voor grond- en gewasonderzoek operationeel die verschillende bemonsteringsmethoden hanteerden (W-methode, Z-methode, kruislingse methode). Nadien zijn drie laboratoria overgenomen en gefuseerd tot Eurofins Agro. Daardoor is de Z-methode niet meer in gebruik. De kruislingse methode wordt slechts bij een beperkt aantal bemonsteringen toegepast. In de praktijk is de $\mathrm{W}$-methode de meest toegepaste methode om een perceel te bemonsteren. Beheersing van onderzoekskosten leidt tot beperking van het onderzoek tot de vergelijking van de gestratificeerde aselecte steekproef met de W-methode van bemonstering.

\section{Doelstelling}

Het onderzoek dient om een bemonsteringsprotocol op te stellen voor het toetsen van de fosfaattoestand van de bodem, ten behoeve van het aanwijzen van een fosfaatgebruiksnorm, bij gebruik van een twee-parametersysteem voor het meten van de fosfaattoestand van de bodem. Daartoe worden de volgende onderzoeksdoelen onderscheiden:

1. Het bepalen van het aantal te nemen steken bij een gestratificeerde aselecte steekproef ter bepaling van een fosfaatarme of fosfaat-fixerend landperceel, bij gebruik van een twee parametersysteem.

2. Het bepalen van de reproduceerbaarheid bij een gestratificeerde aselecte steekproef en bij gebruik van de W-methode;

3. Het beoordelen van de kenmerken van de bemonsteringsmethoden, t.b.v. verificatie van gerapporteerde fosfaattoestanden in het kader van handhaving door de overheid.

Dit rapport is als volgt samengesteld. In hoofdstuk 2 worden de aanpak, de methoden van onderzoek en de databewerking en -verwerking beschreven. Hoofdstuk 3 gaat in op het aantal te nemen steken indien de gestratificeerde aselecte steekproef wijzigt van één indicator voor de fosfaattoestand naar een systeem gebaseerd op de gecombineerde indicator. Hoofdstuk 4 maakt de vergelijking tussen herhaalbaar- en reproduceerbaarheden van de gestratificeerde aselecte steekproef en de toegepaste in-huis-methode van Eurofins Agro. Hoofdstuk 5 meldt de prestatiekenmerken van de bemonsteringsmethoden. Hoofdstuk 6 evalueert verkregen resultaten. Dit mondt uit een in protocol voor bemonstering dat in hoofdstuk 7 wordt gegeven. 


\section{Materiaal en methoden}

\section{$2.1 \quad$ Ontwerp}

Het $\mathrm{P}-\mathrm{CaCl}_{2}$ - en P-AL-getal vormen samen een karakteristiek voor het fosfaatbufferend vermogen van de bodem. Deze combinatie wordt de gecombineerde fosfaatindicator genoemd. Lage waarden voor het $\mathrm{P}-\mathrm{CaCl}_{2}$-getal (een intensiteitsparameter), samengaand met hoge waarden voor het P-AL-getal, (een capaciteitsparameter) wijzen op een sterke buffering van fosfaat. Hoge waarden voor het $\mathrm{P}$ $\mathrm{CaCl}_{2}$-getal, samengaand met lage waarden voor het P-AL-getal, wijzen op een zwakke buffering van fosfaat. Een onderscheid in fosfaatbufferend vermogen is in dit onderzoek opgelegd om te onderzoeken of de bemonsteringsstrategie aangepast dient te worden aan de mate waarin de bodem fosfaat buffert.

Daartoe is een orthogonale proefopzet ontworpen met contrasterende waarden voor het $\mathrm{P}-\mathrm{CaCl}_{2}-\mathrm{en}$ het P-AL-getal. Lage of hoge waarden voor het $\mathrm{P}-\mathrm{CaCl}_{2}$-getal werden gecombineerd met lage of hoge waarden voor het P-AL-getal (zie afbeelding).

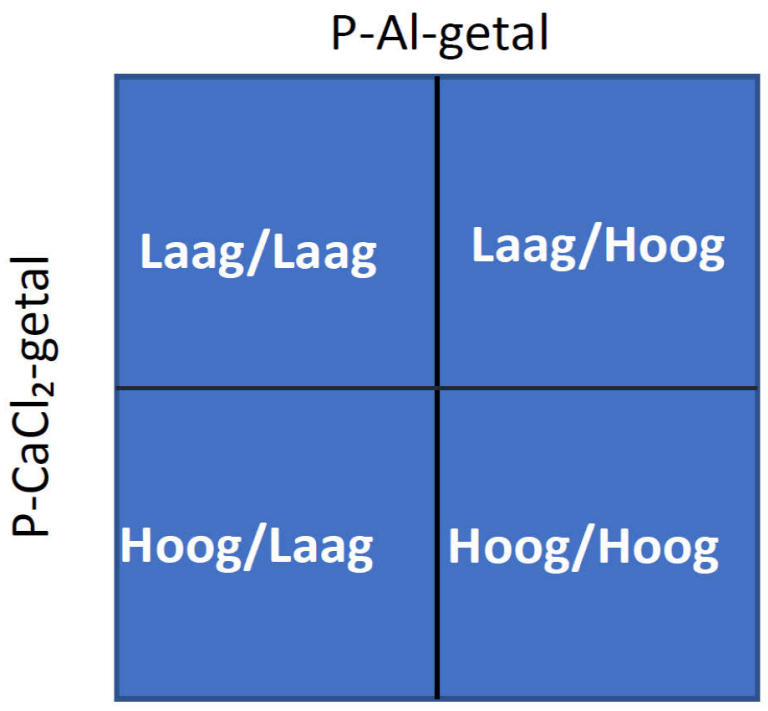

Schematisering van contrasten in fosfaatindicatoren voor intensiteit en capaciteit.

Ter beantwoording van de doelstellingen in dit onderzoek zijn vervolgens de bemonsteringsstrategieën toegepast zoals die door de Meststoffenwet worden voorgeschreven (gestratificeerde aselecte steekproef) of zijn toegelaten (W-methode). Daarnaast is ter controle/verificatie een gestratificeerde aselecte steekproef in groter detail uitgevoerd.

Tevens werd onderzocht of de veronderstelling dat de variatie in de gecombineerde fosfaatindicator bij contrasterende extremen in fosfaattoestanden gemeten als $\mathrm{P}_{-} \mathrm{CaCl}_{2}$-getal of als P-AL-getal inderdaad aanwezig is. Daartoe zijn op grasland en op bouwland vier landbouwpercelen uit de waarderingsklassen laag/laag, laag/hoog, hoog/laag en hoog/hoog met een groter aantallen steken (50) bemonsterd en geanalyseerd. 


\subsection{Selectie van landbouwpercelen met contrasterende fosfaattoestanden}

In de landbouwpraktijk zijn door Eurofins Agro uit hun gegevensbestanden landbouwpercelen geselecteerd die verschillen in $\mathrm{P}-\mathrm{CaCl}_{2}$-getal en $\mathrm{P}-\mathrm{AL}$-getal. Vier combinaties worden getraceerd: laag/laag, laag/hoog, hoog/laag en hoog/hoog. Indicatieve grenswaarden voor laag en hoog voor het $\mathrm{P}-\mathrm{CaCl}_{2}$ - en P-AL-getal zijn gebaseerd op Oenema et al. (2016). Initieel opgelegde criteria voor laag en hoog worden gegeven in Tabel 1 . Bij selectie bleken de initieel opgelegde criteria voor het P-ALgetal te weinig percelen op te leveren, deze criteria werden daarop aangepast (Tabel 1).

Tabel 1 Initieel opgelegde criteria voor toestanden laag en hoog naar Oenema et al. (2016) en na aanpassing i.v.m. verruiming van de selectie.

\begin{tabular}{|c|c|c|c|c|}
\hline \multirow[b]{2}{*}{ Waardering } & \multicolumn{2}{|l|}{ Initieel } & \multicolumn{2}{|l|}{ Aangepast } \\
\hline & $\begin{array}{l}\mathrm{P}-\mathrm{CaCl}_{2} \text {-getal, } \\
\mathrm{mg} \mathrm{P} / \mathrm{kg}\end{array}$ & $\begin{array}{l}\text { P-AL-getal, } \\
\mathrm{mg} \mathrm{P} \mathrm{P}_{2} / 100 \mathrm{~g}\end{array}$ & $\begin{array}{l}\mathrm{P} \text {-CaCl} 2 \text {-getal, } \\
\mathrm{mg} \mathrm{P} / \mathrm{kg}\end{array}$ & $\begin{array}{l}\text { P-AL-getal, } \\
\mathrm{mg} \mathrm{P}_{2} \mathrm{O}_{5} / 100 \mathrm{~g}\end{array}$ \\
\hline Laag & $<1,0$ & $<20$ & $<1,0$ & $<25$ \\
\hline Hoog & $>4,0$ & $>60$ & $>4,0$ & $>50$ \\
\hline
\end{tabular}

Per combinatie van P-CaCl 2 - en P-AL-getal zijn aanvankelijk tien landbouwpercelen geselecteerd: vijf op bouwland en vijf op grasland. Dit levert veertig percelen op grasland en bouwland. Niet alle combinaties werden met die veertig percelen gedekt met vijf herhalingen. Van deze percelen werden acht in groter detail (vijftig strata per perceel) bemonsterd. Een aanvullende bemonstering van een drietal percelen bleek nodig, waaronder een detailbemonstering, omdat niet alle klassen gedekt bleken te zijn. Het totaal aantal percelen is daardoor 43.

Met de aangepaste klasse-indeling werden de landbouwpercelen geselecteerd, bemonsterd en vervolgens werden de grondmonsters geanalyseerd op het $\mathrm{P}-\mathrm{CaCl}_{2}$ - en $\mathrm{P}-\mathrm{AL}$-getal. Het resultaat leerde dat er analyseresultaten waren met fosfaattoestanden die tussen de beoogde indeling van laag en hoog vielen. In het kader van deze studie worden die fosfaattoestanden met 'matig' aangeduid.

Het bestand van Eurofins Agro betrof gegevens van grondonderzoek van het voorliggende bemestingsseizoen. Daardoor werd de bemonstering circa één jaar na de desbetreffende bemonstering waarop het grondonderzoek was gebaseerd, uitgevoerd. Uitsluiten van fosfaatbemesting ${ }^{4}$ behoorde daardoor niet tot een selectiecriterium.

Om tot selectie te komen, werd een veelvoud aan landbouwpercelen geselecteerd. Vervolgens heeft Eurofins Agro toestemming aan de gebruikers en/of eigenaren van deze landbouwpercelen gevraagd om bemonsteringen uit te mogen voeren. Bij toestemming door gebruikers en/of eigenaren werd het desbetreffende landbouwperceel toegevoegd aan de selectie. Tevens werd gevraagd of recentelijk een bekalking was uitgevoerd. Landbouwpercelen die recentelijk ( $<$ twee maanden) bekalkt zijn, vielen buiten de selectie.

Aanvankelijk werd beoogd de areaalgrootte te standaardiseren naar eenzelfde oppervlakte van circa 5 ha. Bij de selectie bleek deze conditie niet opgelegd te kunnen worden, omdat de gewenste combinaties in fosfaattoestanden in te lage aantallen voorkwamen.

\footnotetext{
4 Residuen van fosfaatmeststoffen (minerale meststof of dierlijke mest) kunnen het resultaat van grondonderzoek op fosfaat beïnvloeden. Residuen wateroplosbaar fosfaat van minerale meststof kunnen leiden tot een verhoging van P$\mathrm{CaCl}_{2}$-getal, residuen van in mineraal of organisch zuur oplosbaar fosfaat kunnen in meer of mindere mate leiden tot een verhoging van het P-AL-getal. De fosfaataanvoer is gebonden aan fosfaatgebruiksnormen. Daardoor zijn effecten op wijziging in de fosfaattoestand naar de huidige beeldvorming bescheiden en acceptabel voor dit onderzoek.
} 


\subsection{Bemonsteringen van de bodem}

$\mathrm{Na}$ vaststelling van de definitieve selectie volgt de bemonstering. Alle 43 percelen zijn bemonsterd volgens de gestratificeerde aselecte steekproef én volgens de W-methode. Per perceel zijn voor zowel de gestratificeerde aselecte steekproef en de W-methode drie mengmonsters samengesteld. Voor de gestratificeerde aselecte steekproef is tevens een extra ronde gelopen waarin 19 tot 24 individuele steken zijn verzameld en geanalyseerd. Voor 9 van de 43 percelen zijn 50 individuele steken genomen volgens de gestratificeerde aselecte steekproef en geanalyseerd. Deze afzonderlijk genomen steken hebben tot doel om semivariogrammen te berekenen.

\subsubsection{Bemonstering gebaseerd op de gestratificeerde aselecte steekproef}

De steekproefstrategie volgt hier de voorgeschreven strategie van de Meststoffenwet zoals voorgeschreven in Bijlage $\mathrm{C}$ van de uitvoeringsregeling Meststoffenwet.

In het kort: van het landbouwperceel zullen de omtrek en vorm met gps-coördinaten worden vastgelegd. Bij percelen die in het verleden door Eurofins Agro werden bemonsterd, is deze informatie al beschikbaar. Vervolgens werd het landbouwperceel in het door de Meststoffenwet voorgeschreven aantal even grote compacte blokken opgedeeld. Per blok werd door de computer een bemonsteringslocatie geloot. De gelote locaties werden in een gps opgeslagen Hiervoor is het algoritme gebruikt dat Eurofins Agro hanteert. De monsterplekken zijn met gps opgezocht. De monsternemer kan daarbij gebruikmaken van een geoptimaliseerde route langs de locaties. Deze route is door de computer berekend en is een van de kortst mogelijke routes. Door deze route te volgen, kan het veldwerk efficiënt worden uitgevoerd. Per blok is één grondmonster gestoken ten behoeve van het samenstellen van een semivariogram van het geselecteerde landbouwperceel. Dit grondmonster is door Eurofins Agro geanalyseerd op $\mathrm{P}-\mathrm{CaCl}_{2}$ - en $\mathrm{P}$-AL-getal. Het semivariogram dient de geostatistische analyses ter onderbouwing van het aantal te nemen steken bij de verschillende combinaties van P-CaCl 2 -getal x P-AL-getal.

Om de variatie in de gecombineerde fosfaatindicator tussen contrasterende extremen in fosfaattoestanden gemeten als $\mathrm{P}-\mathrm{CaCl}_{2}$-getal of als $\mathrm{P}$-AL-getal te onderzoeken, zijn semivariogrammen opgesteld door in groter detail grasland en bouwland te bemonsteren. Vier landbouwpercelen op grasof bouwland (dus in totaal $9^{5}$ percelen) met respectievelijk de waarderingsklassen laag/laag, laag/hoog, hoog/laag en hoog/hoog werden met groter aantallen steken (50) bemonsterd en geanalyseerd.

Daarnaast werd een mengmonster van alle monsterplekken gestoken. Dit mengmonster dient ter vergelijking van onderzoeksresultaten verkregen met de W-methode (zie paragraaf 2.3.2). De bemonstering van het mengmonster is nog tweemaal herhaald. Bij een gestratificeerde aselecte steekproef wordt het aantal monsters bepaald door het areaal. Het aantal ligt tussen 19-24 steken. Daardoor is driemaal onafhankelijk gestratificeerd bemonsterd conform bepalingen van de uitvoeringsregeling Meststoffenwet.

De bemonsteringen werden door verschillende monsternemers uitgevoerd.

\subsubsection{Bemonstering gebaseerd op de W-methode}

Hetzelfde perceel werd ook bemonsterd volgens de W-methode. Hierbij is de steekproefstrategie gevolgd volgens de in-huis-methode van Eurofins Agro.

In het kort: per landbouwperceel zijn volgens de W-methode veertig steken genomen. Bij percelen met grotere arealen wordt het perceel opgesplitst in blokken van maximaal 5 ha. In deze studie zijn alle percelen volgens mededeling van Eurofins Agro B.V. met veertig steken bemonsterd. De grond van die veertig steken wordt verzameld tot één grondmonster en door Eurofins Agro geanalyseerd op $\mathrm{P}-\mathrm{CaCl}_{2}$ - en P-AL-getal. Afwijkend van het in-huis-protocol van Eurofins wordt elke bemonsteringsplek

\footnotetext{
${ }^{5}$ Oorspronkelijk acht percelen, een herbemonstering bleek noodzakelijk.
} 
met gps-coördinaten vastgelegd teneinde spiegeling aan de coördinaten van de gestratificeerde aselecte steekproef. Dit werd tweemaal herhaald. In totaal is het landbouwperceel driemaal volgens de W-methode bemonsterd. Daardoor is driemaal onafhankelijk bemonsterd conform in-huisvoorschriften van uitvoerend laboratorium Eurofins Agro.

De bemonsteringen zijn door verschillende monsternemers uitgevoerd.

\subsection{Analyses}

De analyse op $\mathrm{P}-\mathrm{CaCl}_{2}$ - en $\mathrm{P}$-AL-getal zijn uitgevoerd door het geaccrediteerde laboratorium Eurofins Agro conform de door de Meststoffenwet aangewezen of met het ministerie van LNV afgestemde analytische procedures.

\section{$2.5 \quad$ Databewerking}

Om het minimumaantal benodigde steken te berekenen om een mengmonster samen te stellen aan de hand waarvan het perceelgemiddelde $\mathrm{P}-\mathrm{CaCl}_{2}$-getal en $\mathrm{P}-\mathrm{AL}$-getal kunnen worden bepaald met een gegeven totale fout (som van steekproeffout en laboratoriumfout), is de methode gevolgd die staat beschreven in Brus et al. (1999) en Ehlert et al. (2005). De berekening van de nauwkeurigheid als root mean squared error, RMSE, wordt gegeven in Bijlage 5. De toetsing op verschillen berust op Wilcoxon paired test, ook wel Mann-Whitey test genoemd. Uitspraken berusten op een onbetrouwbaarheidsdrempel (a) van $5 \%$ of lager (dan aangegeven). 


\section{Gestratificeerde aselecte steekproef gebaseerd op de gecombineerde indicator}

De gestratificeerde aselecte steekproef staat beschreven in Brus et al. (1999). Het algoritme staat beschreven in Walvoort et al. (2010). Bij deze steekproefmethode wordt een perceel met een computerprogramma opgedeeld in een aantal compacte stukken die even groot zijn. Deze stukken worden geostrata genoemd. Binnen elk geostratum selecteert de computer een willekeurige locatie. Op deze locaties dient een monsternemer steken te nemen van de bovengrond. Om het veldwerk efficiënt te kunnen uitvoeren, heeft de computer de kortste route berekend langs deze locaties. Deze steken worden samengevoegd tot een mengmonster en geanalyseerd in het laboratorium.

In de Staatscourant van 26 juli 2019 (artikel 30) wordt de gecombineerde bodemindicator op basis van het P-AL- en $\mathrm{P}-\mathrm{CaCl}_{2}$-getal voorgesteld om in 2021 het fosfaatgebruiksnormenstelsel te ondersteunen. Tot nu toe wordt de fosfaattoestand gerelateerd aan het P-AL-getal (voor grasland) of het Pw-getal (voor bouwland). Het aantal steken om een gegeven precisie te behalen, was toen vastgesteld op basis van de procedure zoals beschreven in Brus et al. (1999) en Ehlert et al. (2005).

De procedure is opgenomen in Bijlage $C$ van de Uitvoeringsregeling Meststoffenwet (URMW). In deze paragraaf herhalen we deze procedure voor het $\mathrm{P}-\mathrm{AL}-$ en $\mathrm{P}-\mathrm{CaCl}_{2}$-getal.

Onderzocht wordt of door toepassing van de gecombineerde indicator het aantal steken wijzigt ten opzichte van de door de Meststoffenwet voorgeschreven aantal steken. In Bijlage $\mathrm{C}^{6}$ van de URMW is het aantal steken onderbouwd door een steekproeffout te voorspellen met een model van de ruimtelijke variatie (semivariogram), waarbij vervolgens de variantie van de laboratoriumfout werd opgeteld. ${ }^{7}$ De som van de steekproeffout en laboratoriumfout noemen we in deze context de totale fout.

\footnotetext{
6 https://wetten.overheid.nl/BWBR0018989/2020-08-01\#BijlageC

7 Gerekend is in 2005 met een sferische semivariogram met een nugget (intercept) van 50, een sill (asymptoot) van 100 en een range van $50 \mathrm{~m}$. Bij de modelvoorspelling van de steekproefvariantie is vervolgens de variantie van de laboratoriumfout opgeteld. Hiervoor is de waarde 2,5 genomen (Brus e.a., 1999b).
} 

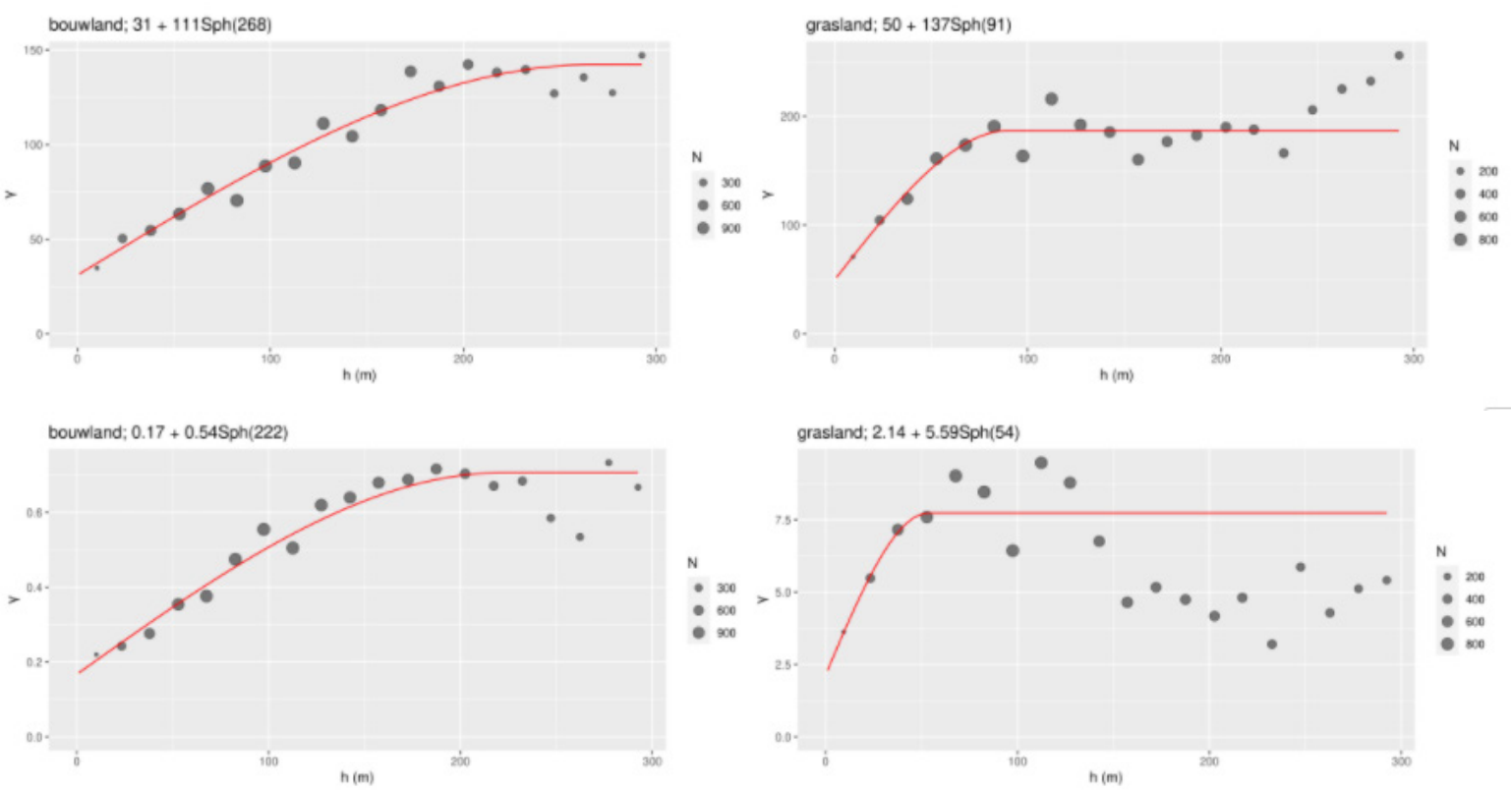

Figuur 1 Semivariogrammen voor het $P$-AL-getal voor bouwland (linksboven) en grasland (rechtsboven) en het $\mathrm{P}$ - $\mathrm{CaCl}_{2}$-getal voor bouwland (linksonder) en grasland (rechtsonder). Op de $y$-as staat de semivariantie $Y$ (in dezelfde eenheid in het kwadraat als de betreffende $P$-parameter) en op de $x$-as de afstand tussen twee willekeurige locaties in het perceel (in meters). Hoe groter de afstand tussen twee locaties in een perceel, hoe groter de semivariantie en hoe meer de P-parameters van elkaar zullen verschillen, totdat een maximum wordt bereikt.

Figuur 1 geeft een viertal semivariogrammen van bemonsterde landbouwpercelen. Het semivariogram geeft aan in hoeverre waarden op locaties die op een onderlinge afstand, $h$, van elkaar liggen nog op elkaar lijken. Uit de figuur blijkt dat locaties die dicht bij elkaar liggen (kleine $h$ ), P-AL-getal of P$\mathrm{CaCl}_{2}$-getal-waarden hebben die meer op elkaar lijken (kleinere semivariantie) dan locaties die verder uiteen liggen (grote $h$ en grotere semivariantie). De semivariogrammen zijn onderbouwd door de gegevens van alle 43 percelen samen te voegen (gepooled semivariogram).

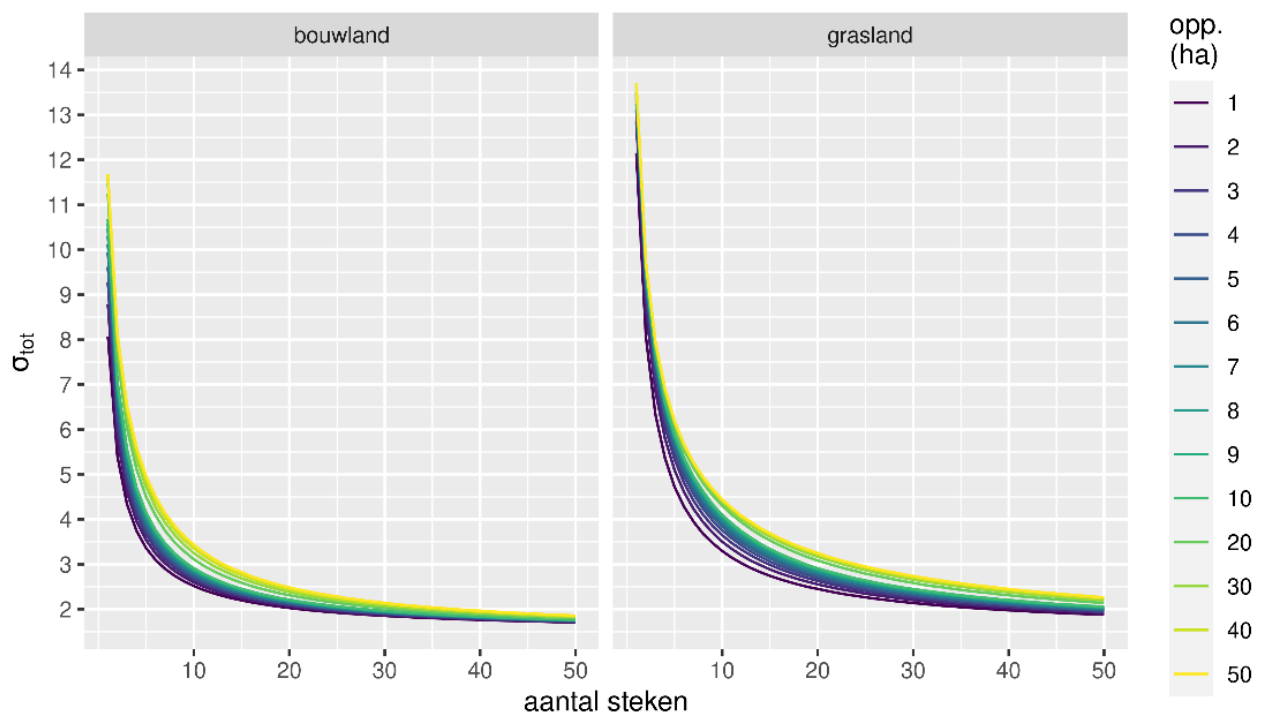

Figuur 2 De totale fout $\left(\sigma_{\text {tot }}\right)$ voor P-AL-getal die bestaat uit twee componenten, te weten de steekproeffout en de laboratoriumfout als functie van het aantal steken voor bouwland (links) en grasland (rechts) voor percelen van verschillende oppervlakten (kleur van de curves). 
In Figuur 2 staat de totale fout uitgedrukt als functie van het aantal steken voor bouwland (links) en grasland (rechts) voor het P-AL-getal. In Figuur 3 staat de totale fout uitgedrukt als functie van het aantal steken voor bouwland (links) en grasland (rechts) voor het P-CaCl 2 -getal. We hebben hierbij dezelfde procedure gevolgd als in Ehlert et al. (2005). Zie ook Bijlage 1 voor een korte samenvatting. De totale fout is hierbij gedefinieerd als de som van steekproeffout en laboratoriumfout. De standaardafwijking van de totale fout is een absolute waarde en uitgedrukt in dezelfde eenheid als de betreffende P-parameter. De curves hebben betrekking op perceelgroottes variërend van 1 tot 50 ha. We zien dat bij het $\mathrm{P}-\mathrm{CaCl}_{2}$-getal voor grasland meer steken nodig zijn dan voor bouwland bij eenzelfde totale fout. Dit geldt ook voor P-AL-getal, maar is hier minder contrasterend. Dit wordt mogelijk veroorzaakt door het ontbreken van grondbewerking bij grasland. Ook zien we dat voor grote percelen meer steken nodig zijn, maar dat het aantal steken niet proportioneel toeneemt met de perceelgrootte.

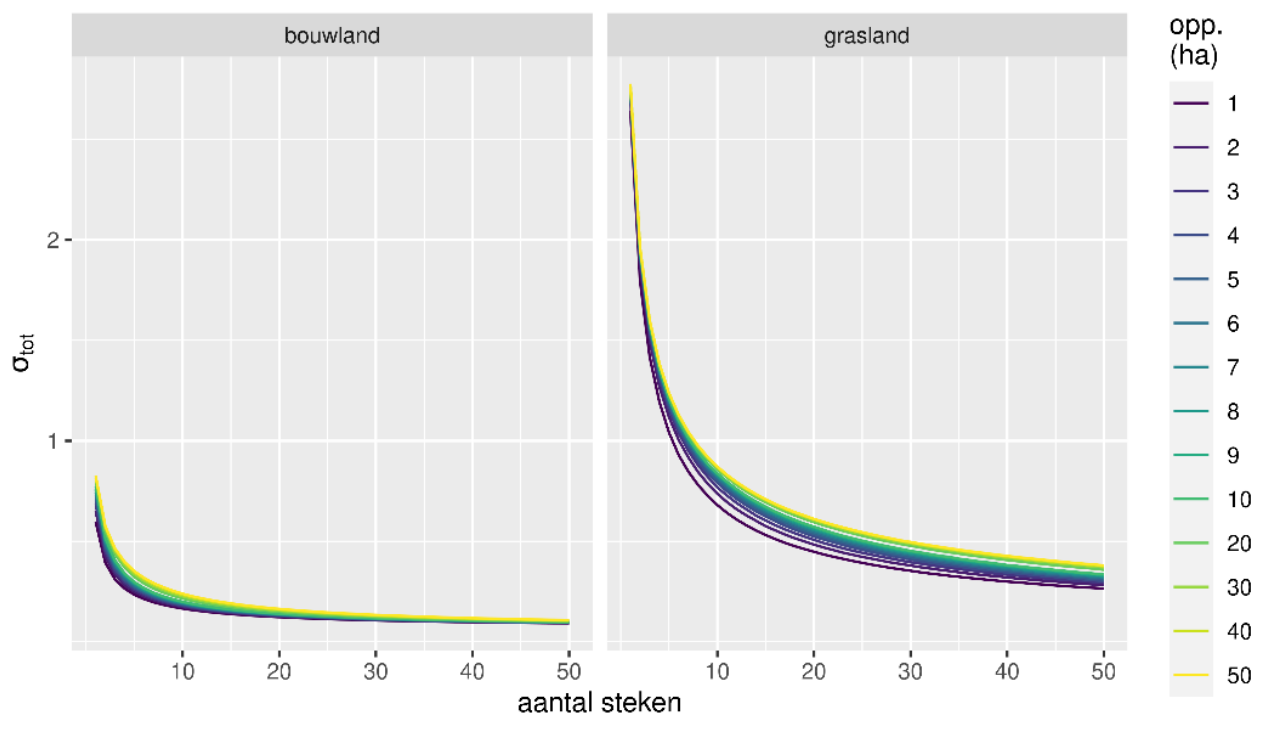

Figuur 3 De totale fout $\left(\sigma_{\text {tot }}\right)$ voor $\mathrm{P}-\mathrm{CaCl}_{2}$-getal die bestaat uit twee componenten, te weten de steekproeffout en de laboratoriumfout als functie van het aantal steken voor bouwland (links) en grasland (rechts) voor percelen van verschillende oppervlakten (kleur van de curves).

De totale fouten zijn verkregen door uit Figuur 2 en Figuur 3. De totale fout $\sigma_{\text {tot }}$ af te lezen bij 25 steken voor een perceel van 5 ha voor bouwland en grasland. In deze studie is gekozen voor een totale fout gebaseerd op 25 steken, bij hogere aantallen steken neemt deze fout nauwelijks af bij bouwland, terwijl bij grasland nog sprake is van enige afname; bij lagere aantallen neemt deze fout fors toe. In deze studie komt 5 ha ruwweg overeen met de mediane areaalgrootte. Bij kleinere percelen neemt de totale fout weliswaar af, maar dat heeft weinig effect op het aantal te nemen steken.

De totale fouten zijn:

- 2,0 mg $\mathrm{P}_{2} \mathrm{O}_{5} / 100 \mathrm{~g}$ voor P-AL-getal en bouwland

- 2,5 mg $\mathrm{P}_{2} \mathrm{O}_{5} / 100 \mathrm{~g}$ voor P-AL-getal en grasland

- $0,12 \mathrm{mg} \mathrm{P} / \mathrm{kg}$ voor P-CaCl -getal en bouwland

- 0,47 mg P/kg voor P-CaCl 2 -getal en grasland

Tabel 2 geeft het minimale aantal steken dat nodig is om een mengmonster samen te stellen voor het $\mathrm{P}$-AL- en $\mathrm{P}-\mathrm{CaCl}_{2}$-getal, zodat de standaardafwijking van de totale fout $\sigma_{\text {tot }}$ kleiner is dan een gegeven grenswaarde. De tabel geeft dit aantal steken voor zowel grasland als bouwland en voor verschillende perceelgroottes, gegeven dat er één mengmonster wordt samengesteld en in duplo wordt geanalyseerd. 
De gemaakte keuzes (areaal van 5 ha en 25 steken) dienen als referentie. Zou een andere keuze gemaakt worden, bijvoorbeeld een areaalgrootte van 3 ha en 25 steken, dan resulteert dit in een kleinere totale fout, en bij grotere arealen in meer steken.

Tabel 2 Minimale aantal benodigde steken om bij genoemde totale fout uit te komen voor het $P$-AL- en $\mathrm{P}-\mathrm{CaCl}_{2}$-getal voor bouwland en grasland, gegeven dat er één mengmonster wordt samengesteld en in duplo wordt geanalyseerd. De standaardafwijking van de totale fout waarop het aantal benodigde steken is gebaseerd, staat onder het kopje vermeld.

\begin{tabular}{|c|c|c|c|c|}
\hline \multirow{2}{*}{$\begin{array}{l}\text { Oppervlakte perceel, } \\
\text { ha }^{8}\end{array}$} & \multicolumn{2}{|l|}{ P-AL-getal } & \multicolumn{2}{|l|}{ P-CaCl 2 -getal } \\
\hline & $2,0 \mathrm{mg} \mathrm{P}_{2} \mathrm{O}_{5} / 100 \mathrm{~g}$ & $2,5 \mathrm{mg} \mathrm{P}_{2} \mathrm{O}_{5} / 100 \mathrm{~g}$ & $0,12 \mathrm{mg} P / \mathrm{kg}$ & $0,47 \mathrm{mg} P / \mathrm{kg}$ \\
\hline 2 & 22 & 21 & 22 & 21 \\
\hline 3 & 23 & 23 & 23 & 23 \\
\hline 5 & 25 & 25 & 25 & 25 \\
\hline 6 & 26 & 26 & 26 & 26 \\
\hline 7 & 26 & 27 & 26 & 26 \\
\hline 8 & 27 & 27 & 27 & 27 \\
\hline 30 & 34 & 35 & 34 & 32 \\
\hline 40 & 35 & 37 & 36 & 33 \\
\hline 50 & 37 & 38 & 37 & 33 \\
\hline
\end{tabular}

Het gebruik van een gecombineerde indicator op grasland vraagt meer steken op grasland; op bouwland kan volstaan worden met minder steken. Echter, doordat wij een referentieperceeloppervlakte hanteren van 5 ha met daarbij een vast aantal steken van 25, verdwijnt dit onderscheid in landgebruik. Bij andere keuzen veranderen de waarden van Tabel 2. Overwogen kan worden om het aantal steken te laten afhangen van het landgebruik dat een hoger aantal steken nodig heeft. Dit is in dit onderzoek grasland.

\section{In het kort}

In 2005 zijn landbouwpercelen met een lage fosfaattoestand geselecteerd. Bij lage fosfaattoestanden is de meetfout in absolute zin laag. In deze studie zijn percelen met lage en hoge fosfaattoestanden geselecteerd. Daardoor zijn gegevens aanwezig van fosfaattoestanden met hoge waarden, waarbij de meetfout in absolute zin hoger is (Ehlert et al., 2007). Een hogere meetfout leidt tot een hoger aantal te nemen steken.

De huidige resultaten bevestigen de resultaten van het onderzoek in 2005 dat het aantal steken niet evenredig toeneemt met de grootte van het areaal landbouwperceel. Voor een graslandperceel van 10 ha zijn 29 steken nodig, terwijl voor een tweemaal zo groot graslandperceel van 20 ha 33 steken nodig zijn.

\footnotetext{
8 De maximale perceelsgrootte is ca. 19 ha. Omdat de semivariogrammen geen duidelijke trend laten zien en we het semivariogram alleen gebruiken om de gemiddelde semivariantie binnen compacte blokken uit te rekenen, kunnen we ook het aantal steken berekenen voor perceelsgroottes groter dan 19 ha.
} 


\section{$4 \quad$ Herhaalbaarheid, reproduceerbaarheid en nauwkeurigheid van gestratificeerde aselecte steekproef en W-methode}

In dit hoofdstuk onderzoeken wij of de gestratificeerde aselecte steekproef en de in-huis-methode van Eurofins Agro, de W-methode, tot een gelijkluidende uitslag komen bij de bepaling van de fosfaattoestand van de bodem bij toepassen van de gecombineerde indicator.

We maken daarbij een onderscheid tussen herhaalbaarheid, reproduceerbaarheid en nauwkeurigheid.

Onder herhaalbaarheid verstaan we:

De mate van overeenstemming tussen de resultaten van opeenvolgende metingen van dezelfde meetgrootheid, die onder identieke meetomstandigheden zijn verricht.

Onder reproduceerbaarheid verstaan we:

De mate van overeenstemming tussen de meetresultaten van dezelfde meetgrootheid, verkregen onder wisselende meetomstandigheden. De wisselende omstandigheden kunnen omvatten: de waarnemer, het meetinstrument, de plaats en de tijd.

Onder nauwkeurigheid verstaan we:

De mate van overeenstemming van een gemeten of bekende waarde met haar daadwerkelijke waarde. ${ }^{9}$

\subsection{Herhaalbaarheid}

\subsubsection{Afleiding van de herhaalbaarheid}

De gestratificeerde aselecte steekproef en de W-methode zijn elk drie keer uitgevoerd. Deze gegevens kunnen we gebruiken om de mate van herhaalbaarheid te kwantificeren. De herhaalbaarheid heeft daarmee betrekking op zowel de monsterneming als de laboratoriumanalyses. Als maat voor de herhaalbaarheid gebruiken we de variatiecoëfficiënt. Deze is gedefinieerd als het quotiënt van de standaarddeviatie $s$ en het gemiddelde $m$ :

$c_{v}=100 \frac{s}{m}$

waarin $m$ het gemiddelde is van $n$ bepalingen. De variatiecoëfficiënt is uitgedrukt als een percentage. In ons geval geldt $n=3$. De optimale waarde van de variatiecoëfficiënt is nul. In dat geval is de analyse perfect herhaalbaar. Echter, doordat percelen ruimtelijke variatie vertonen in P-AL-getal en $\mathrm{P}-\mathrm{CaCl}_{2}-$ getal en er altijd sprake zal zijn van een laboratoriumfout, zal de variatiecoëfficiënt groter zijn dan nul.

In Figuur 4 en Figuur 5 zijn histogrammen van de variatiecoëfficiënten gegeven voor respectievelijk het P-AL-getal en het $\mathrm{P}-\mathrm{CaCl}_{2}$-getal. Elk histogram geeft de variatiecoëfficiënt weer voor de drie herhalingen voor de 43 percelen, opgedeeld naar bemonsteringsmethode en landgebruik.

\footnotetext{
9 Conform Everitt en Skrondal (2010).
} 
De variatiecoëfficiënten voor $\mathrm{P}-\mathrm{CaCl}_{2}$-getal en $\mathrm{P}$-AL-getal zijn van eenzelfde ordegrootte.

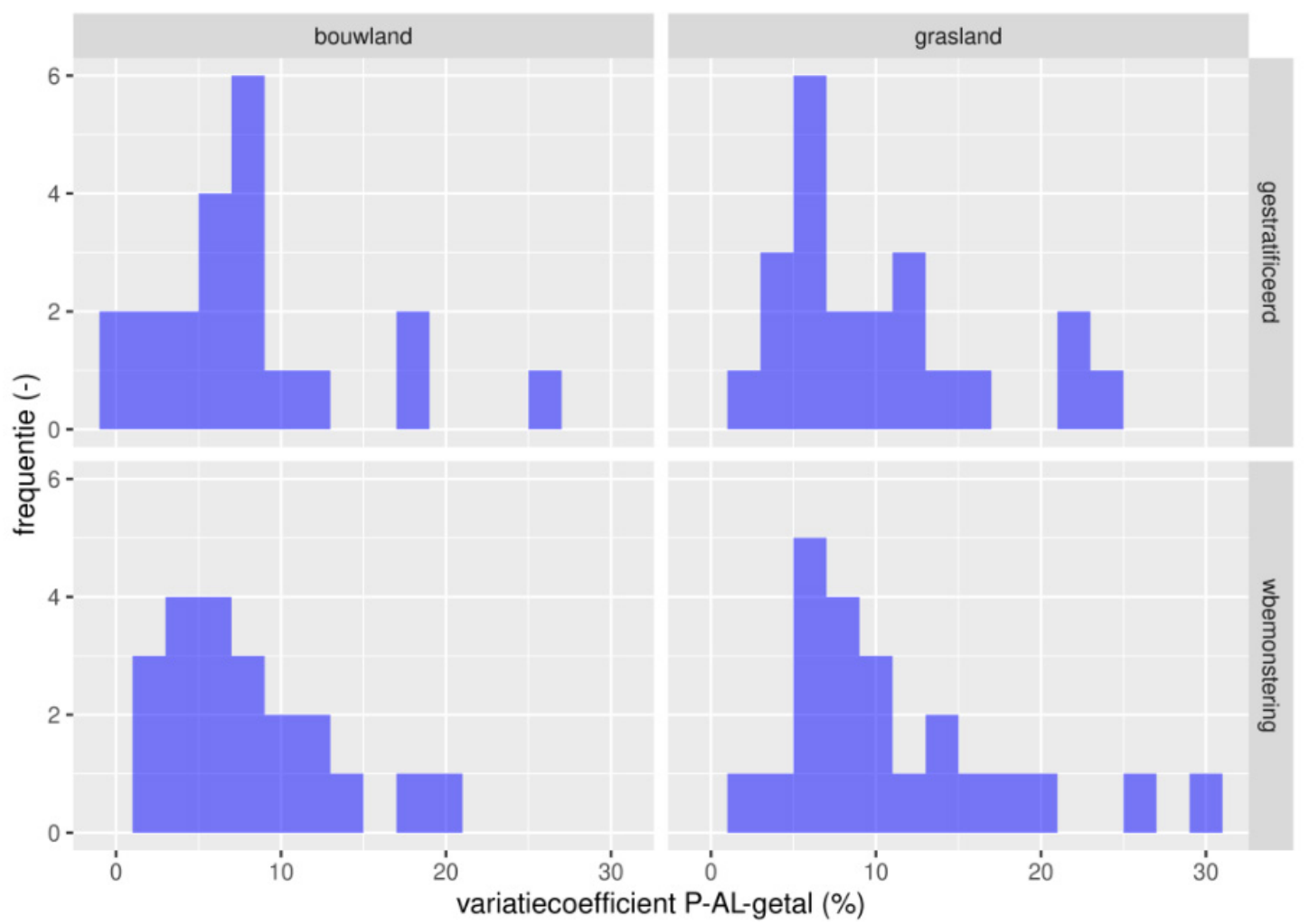

Figuur 4 Histogrammen van de variatiecoëfficiënten voor het P-AL-getal voor de gestratificeerde steekproef en de W-methode, opgesplitst naar landgebruik.

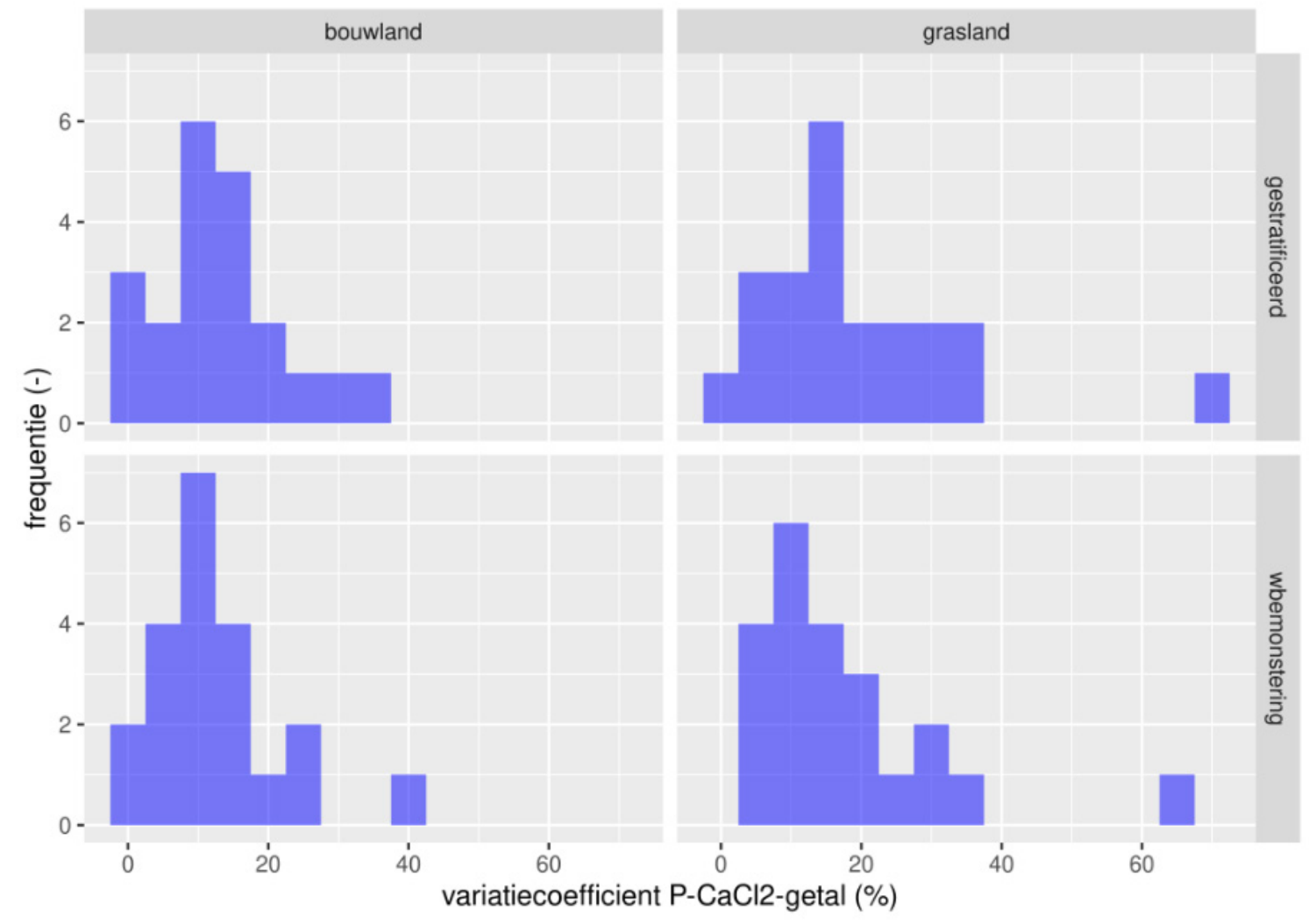

Figuur 5 Histogrammen van de variatiecoëfficiënten voor het $\mathrm{P}-\mathrm{CaCl}_{2}$-getal voor de gestratificeerde steekproef en de W-methode, opgesplitst naar landgebruik. 


\subsubsection{Toepassing van herhaalbaarheden van de twee bemonsteringsstrategieën}

In de Staatscourant van 26 juli 2019 (artikel 30) zijn tabellen gegeven voor een gecombineerde indicator voor de fosfaattoestand (zie voetnoot ${ }^{10}$ ). Deze is gebaseerd op zowel het P-CaCl 2 -getal als het P-AL-getal en resulteert in kwalitatieve aanduidingen voor de fosfaattoestand: arm, laag, neutraal, ruim en hoog.

Door de drie herhalingen per perceel te classificeren volgens deze tabel kan worden gekeken in hoeverre een herhaling dezelfde klasse oplevert. De resultaten zijn voor de twee bemonsteringsmethoden weergegeven in Figuur 6. We zien dat de klassen meestal identiek zijn voor de drie herhalingen (linker staaf). Echter, in een aantal gevallen zijn er twee klassen (tweede staaf), en in een enkel geval zelfs drie klassen (derde staaf). Dat laatste wil zeggen dat elke herhaling resulteert in een andere fosfaattoestandsklasse. Voor de gestratificeerde methode zijn voor 34 percelen de klassen voor de herhalingen identiek en voor 9 percelen verschillend. Voor de Wmethode zijn voor 32 percelen de klassen voor de herhalingen identiek en voor 11 percelen verschillend.

\begin{tabular}{|c|c|c|c|c|c|}
\hline \multirow{2}{*}{$\begin{array}{l}\text { Indeling klassen } \mathrm{P} \text { - } \\
\mathrm{CaCl}_{2} \text {-getal(mg } \\
\mathrm{P} / \mathrm{kg})\end{array}$} & \multicolumn{5}{|c|}{ Indeling klassen P-AL-getal $\left(\mathrm{mg} \mathrm{P}_{2} \mathrm{O}_{5} / 100 \mathrm{~g}\right)$} \\
\hline & $<21$ & $\begin{array}{l}21 \text { tot en met } \\
30\end{array}$ & $\begin{array}{l}31 \text { tot en met } \\
45\end{array}$ & $\begin{array}{l}46 \text { tot en met } \\
55\end{array}$ & $>55$ \\
\hline$<0,8$ & arm & laag & laag & neutraal & ruim \\
\hline 0,8 tot en met 1,4 & arm & laag & neutraal & ruim & ruim \\
\hline 1,5 tot en met 2,4 & laag & neutraal & ruim & ruim & hoog \\
\hline 2,5 tot en met 3,4 & neutraal & ruim & ruim & hoog & hoog \\
\hline$>3,4$ & ruim & ruim & hoog & hoog & hoog \\
\hline
\end{tabular}

Tabel II. Bouwland

\begin{tabular}{|c|c|c|c|c|c|}
\hline \multirow{2}{*}{$\begin{array}{l}\text { Indeling klassen P- } \\
\mathrm{CaCl}_{2} \text {-getal (mg } \\
\mathrm{P} / \mathrm{kg} \text { ) }\end{array}$} & \multicolumn{5}{|c|}{ Indeling klassen P-AL-getal $\left(\mathrm{mg} \mathrm{P}_{2} \mathrm{O}_{5} / 100 \mathrm{~g}\right)$} \\
\hline & $<21$ & $\begin{array}{l}21 \text { tot en met } \\
30\end{array}$ & $\begin{array}{l}31 \text { tot en met } \\
45\end{array}$ & $\begin{array}{l}46 \text { tot en met } \\
55\end{array}$ & $>55$ \\
\hline$<0,8$ & arm & arm & arm & laag & laag \\
\hline 0,8 tot en met 1,4 & arm & arm & arm & laag & neutraal \\
\hline 1,5 tot en met 2,4 & arm & arm & laag & neutraal & ruim \\
\hline 2,5 tot en met 3,4 & arm & laag & neutraal & ruim & hoog \\
\hline$>3,4$ & laag & laag & neutraal & ruim & hoog \\
\hline
\end{tabular}




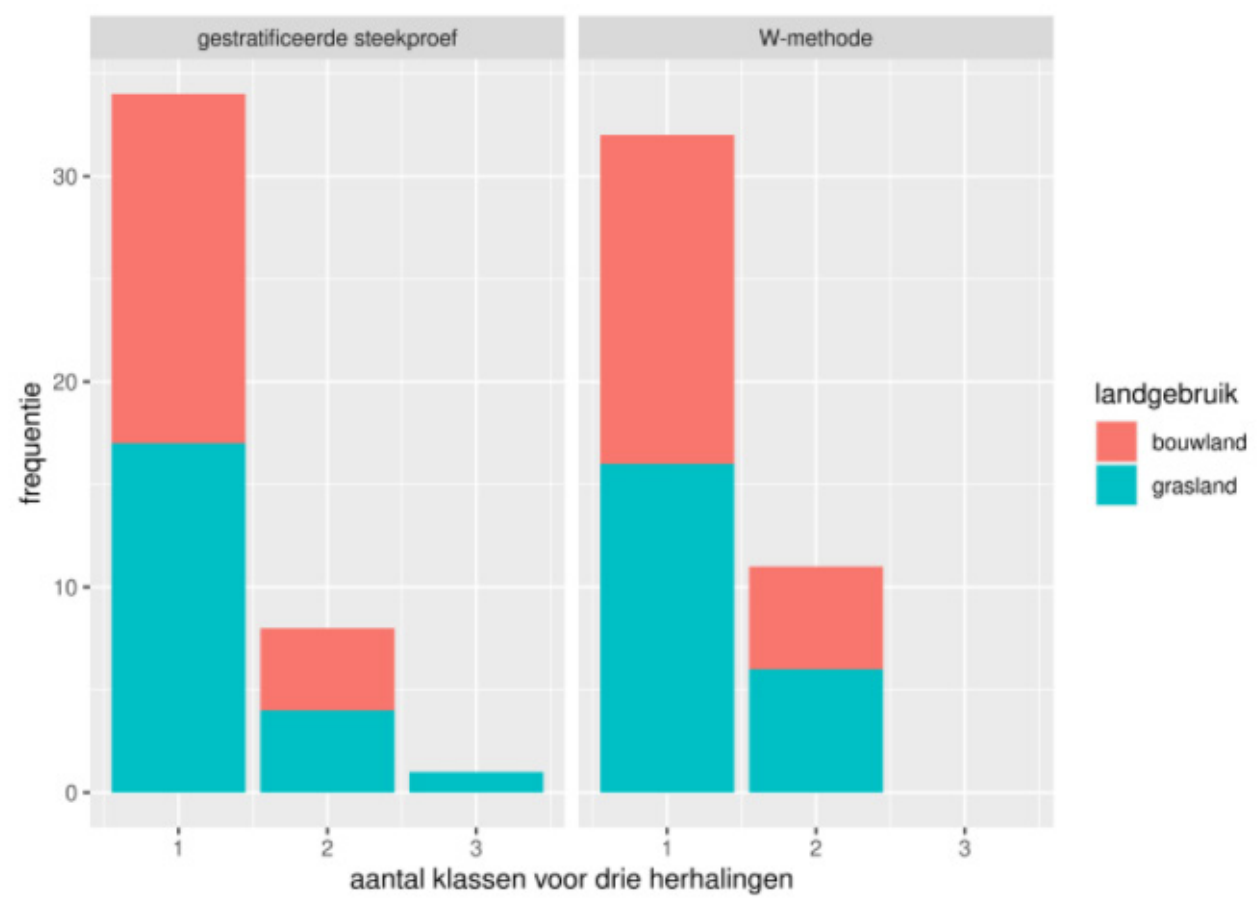

Figuur 6 Aantal keer dat de drie herhalingen per perceel uit 1, 2 of 3 klassen bestaan voor zowel de gestratificeerde steekproef (links) als de W-bemonstering (rechts). De kleuren geven de bijdrage van bouwland en grasland weer.

\subsection{Reproduceerbaarheid}

De reproduceerbaarheid hebben we inzichtelijk gemaakt door de metingen van het huidige seizoen te vergelijken met die van het vorige seizoen. Naast de variatie in fosfaattoestand binnen het perceel, en de laboratoriumfout, speelt hier ook de variatie veroorzaakt door managementactiviteiten van het afgelopen jaar een rol. Hieronder valt fosfaatbemesting. Welke fosfaatbemesting werd toegediend, is onbekend.

In Figuur 7 en Figuur 8 zijn respectievelijk het P-AL-getal en het $\mathrm{P}-\mathrm{CaCl}_{2}$-getal op basis van het selectiecriterium (2.2 Tabel 1 Aangepast) uitgezet tegen die van de herbemonstering (voor deze studie). Omdat het $\mathrm{P}-\mathrm{CaCl}_{2}$-getal een intensiteitsparameter is, verwachten we hier enige variatie. Bij capaciteitsparameter P-AL-getal verwachten we minder variatie. Omdat de percelen nog steeds in productie zijn en worden bemest, verwachten we dat het P-AL-getal in het huidige seizoen vergelijkbaar is aan of hoger is dan het P-AL-getal in het vorige seizoen. Met andere woorden, we verwachten de punten rond of boven de rode lijn (1:1-lijn). We zien echter ook flinke afnames in het P-AL-getal, met name bij bouwland. Deze worden mogelijk veroorzaakt door de ruimtelijke en temporele variatie van het P-AL-getal binnen de percelen en dientengevolge een fout in de geschatte fosfaattoestand van het perceel op beide tijdstippen en door de managementpraktijk (bouwplanbemesting). ${ }^{11}$

\footnotetext{
${ }^{11} \mathrm{Bij}$ toepassen van bouwplanbemesting wordt de totale fosfaatbemesting van een bouwplan toegediend aan op fosfaat reagerende gewassen. Dit zijn de hakvruchten. De graangewassen ontvangen dan geen fosfaatbemesting. Het is mogelijk dat in dit onderzoek bouwlandpercelen na de teelt van graan werden bemonsterd in een jaar dat geen fosfaatbemesting werd toegepast.
} 


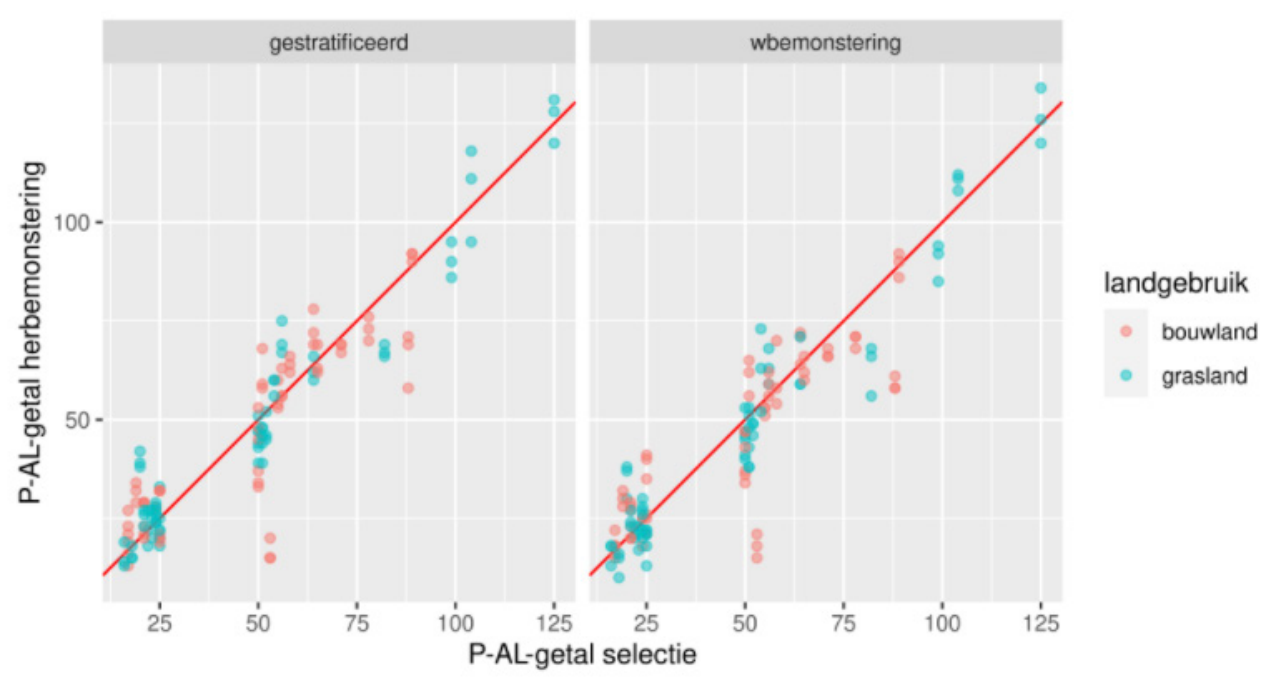

Figuur $7 \quad$ Vergelijking van het P-AL-getal op basis van het selectiecriterium van Tabel 1 met die verkregen op basis van herbemonstering. De verschillen zijn een maat voor de reproduceerbaarheid.

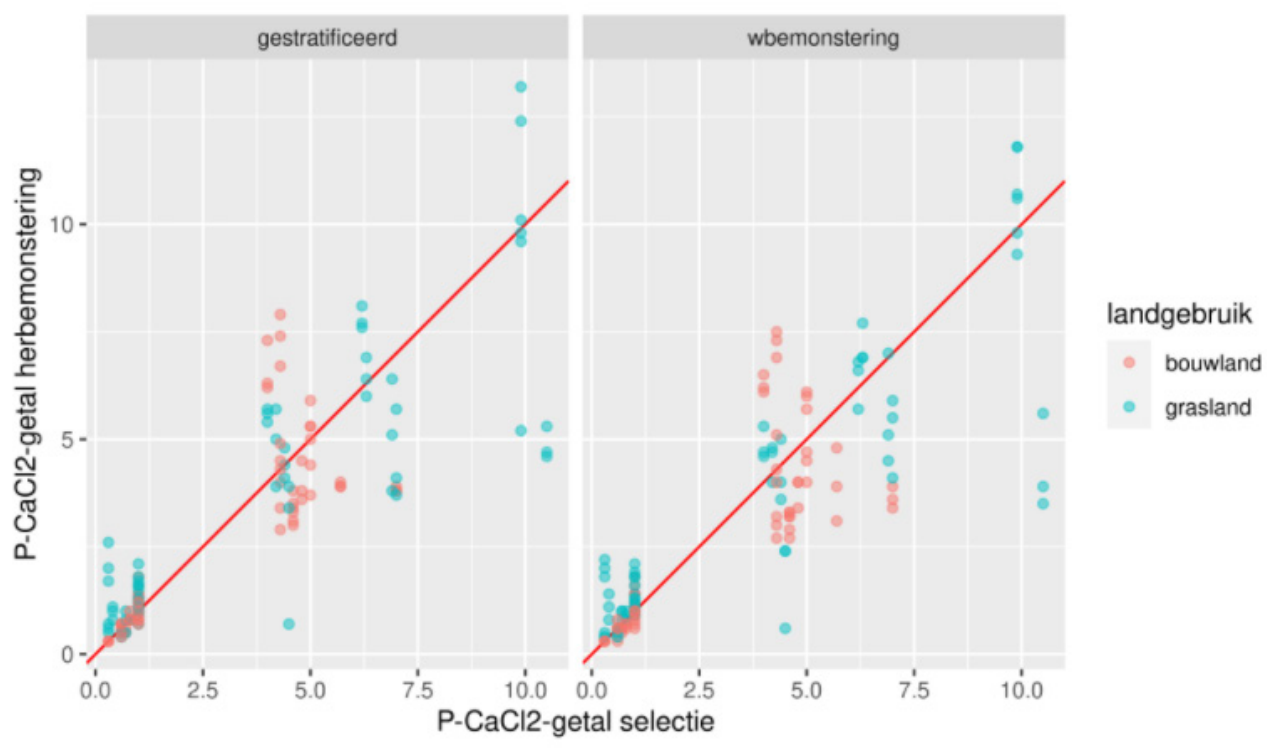

Figuur $8 \quad$ Vergelijking van het $\mathrm{P}-\mathrm{CaCl}_{2}$-getal op basis van het selectiecriterium van Tabel 1 met die verkregen op basis van herbemonstering. De verschillen zijn een maat voor de reproduceerbaarheid.

\subsection{Nauwkeurigheid}

De wortel uit de gemiddelde gekwadrateerde fout (root mean squared error, RMSE) wordt gebruikt als maat voor de nauwkeurigheid. In Bijlage 5 geven we aan hoe de RMSE wordt berekend uit de beschikbare gegevens.

In Figuur 9 is de RMSE voor de W-methode uitgezet tegen die van de gestratificeerde aselecte steekproef. Dit is gedaan voor het P-AL-getal (links) en het $\mathrm{P}-\mathrm{CaCl}_{2}$-getal (rechts). Elk punt heeft betrekking op een perceel. Voor punten boven de rode lijn is de RMSE voor de W-methode hoger en voor punten beneden de rode lijn is de RMSE voor de gestratificeerde aselecte steekproef hoger. Hoe kleiner de RMSE, hoe groter de nauwkeurigheid.

We zien dat voor het P-AL-getal een groot deel van de punten boven de rode lijn ligt. Dat wil zeggen dat dan de nauwkeurigheid hoger is voor de gestratificeerde aselecte steekproef. Dit hebben we formeel statistisch getoetst met een eenzijdige, niet-parametrisch gepaarde toets, de Wilcoxon 
gepaarde waarnemingen toets (Wilcoxon paired test, ook wel Mann-Whitey test genoemd). Daaruit bleek dat de nauwkeurigheid van de gestratificeerde aselecte steekproef voor het P-AL-getal significant $(p<0.001)$ groter is dan die van de $W$-methode. Het mediane verschil in RMSE bedraagt $0,87 \mathrm{mg} \mathrm{P}_{2} \mathrm{O}_{5} / 100 \mathrm{~g}$.

Voor de RMSE voor het $\mathrm{P}-\mathrm{CaCl}_{2}$-getal konden we met de genoemde toets op grond van de gegevens geen significant hogere nauwkeurigheid voor de gestratificeerde aselecte steekproef aantonen $(p=0,11)$.

Dit zijn interessante resultaten, mede doordat voor de W-methode twee keer zoveel steken worden genomen als voor de gestratificeerde aselecte steekproef. Zouden we het aantal steken gelijktrekken, dan zouden we grotere verschillen verwachten.
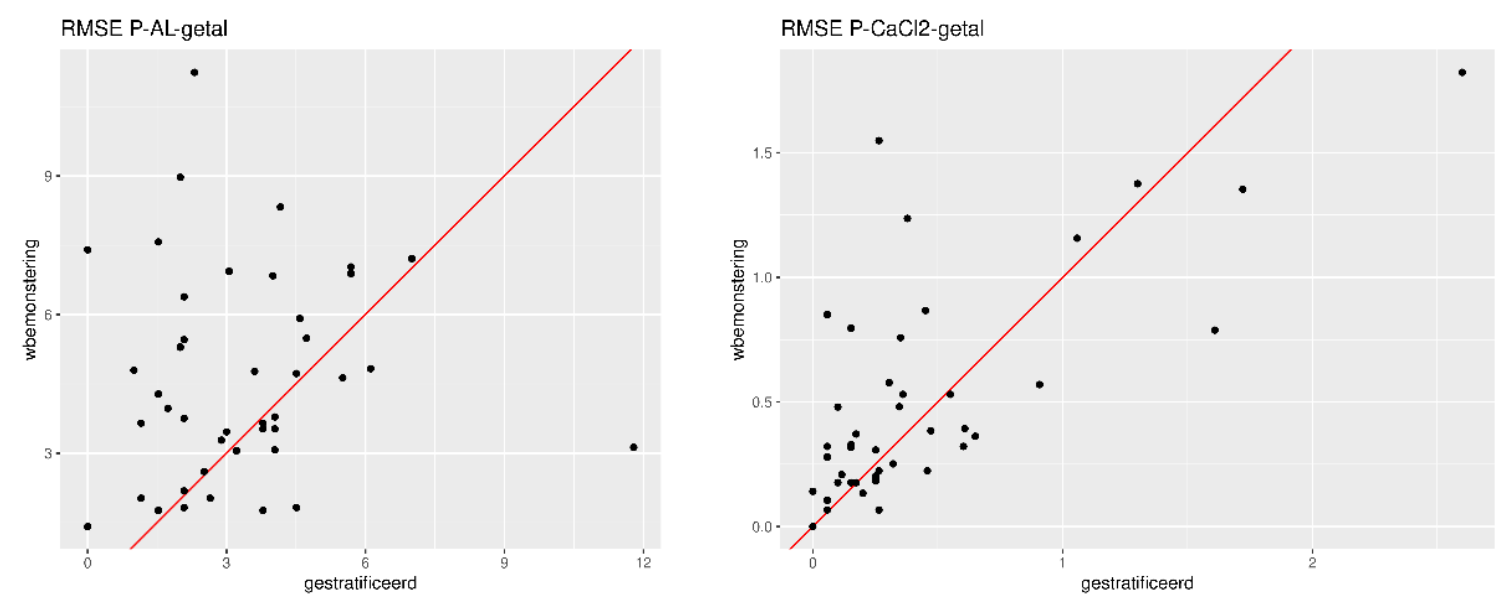

Figuur 9 De nauwkeurigheid (RMSE) voor de W-methode, uitgezet tegen die van de gestratificeerde aselecte steekproef voor het $P$-AL-getal (links) en het $P$ - $\mathrm{CaCl}_{2}$-getal (rechts).

\subsection{Ruimtelijke variatie}

Bij herbemonstering werd vastgesteld dat de lage fosfaattoestanden hoger waren dan beoogd en hoge fosfaattoestanden lager. De beoogde contrasten in fosfaatklassen konden daarop niet worden aangebracht. Er is daarom overgestapt naar een observationele statistische verwerking van de data.

Deze paragraaf geeft resultaten van bewerking.

Figuur 10 geeft de ruimtelijke variatie van het P-AL-getal weer voor vier percelen. We zien dat waarden binnen een perceel aanzienlijk kunnen verschillen. Bij perceel 9 bijvoorbeeld zien we hogere waarden in het noordwesten dan in het zuiden.

Figuur 11 geeft de ruimtelijke variatie van het $\mathrm{P}-\mathrm{CaCl}_{2}$-getal weer voor dezelfde vier percelen. Ook hier is zien we grote verschillen binnen percelen. Het is daarom van belang dat alle locaties in het perceel potentieel bemonsterd kunnen worden en dat een bemonsteringsmethode niet bij voorbaat al delen uitsluit door constructie.

In Bijlage 3 en 4 zijn voor respectievelijk het P-AL- en $\mathrm{P}-\mathrm{CaCl}_{2}$-getal soortgelijke kaartjes opgenomen voor de overige percelen. 


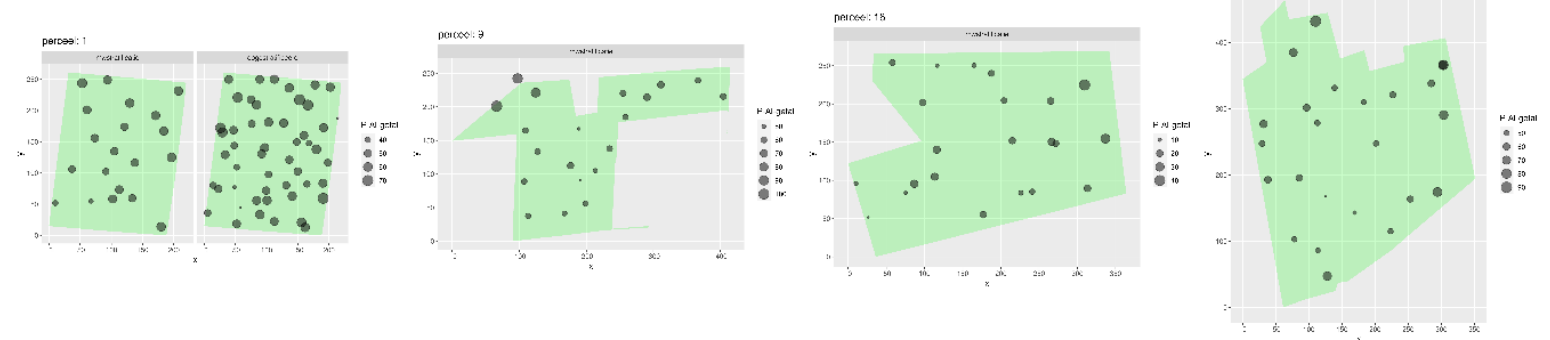

Figuur 10 Gemeten P-AL-getal per steek voor vier percelen bemonsterd volgens de gestratificeerde aselecte steekproef. De grootte van de punten is evenredig met het $P$-AL-getal $\left(\mathrm{mg} \mathrm{P}_{2} \mathrm{O}_{5}(100 \mathrm{~g})^{-1}\right)$. Perceel 1 is twee keer bemonsterd, met een verschillend aantal steken (links 20, rechts 50).

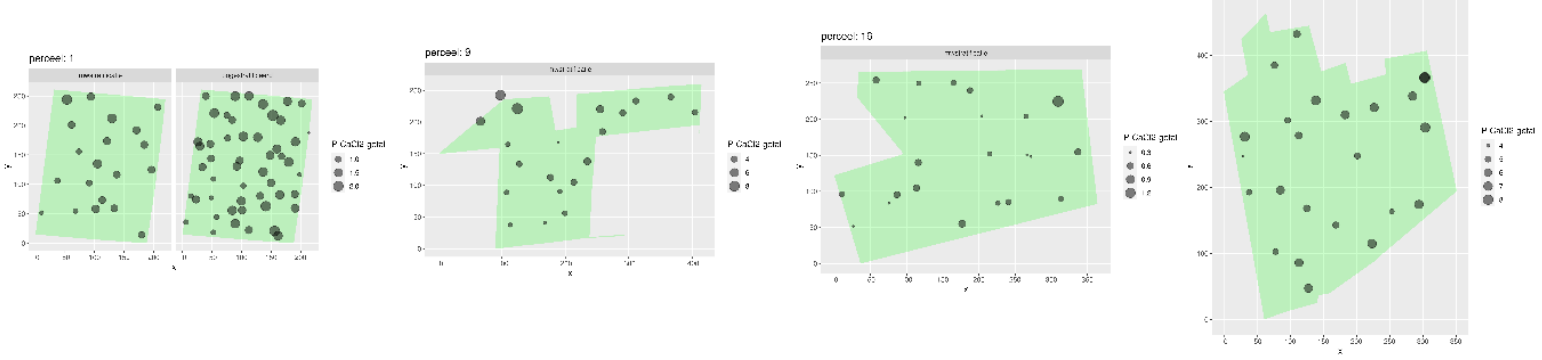

Figuur 11 Gemeten P-CaCl 2 -getal per steek voor vier percelen, bemonsterd volgens de gestratificeerde aselecte steekproef. De grootte van de punten is evenredig met het $P-C_{2} \mathrm{Cl}_{2}-$ getal ( $\mathrm{mg}$ $P \mathrm{~kg}^{-1}$ ). Perceel 1 is twee keer bemonsterd, met een verschillend aantal steken (links 20, rechts 50).

Figuur 12 en Figuur 13 geven de semivariogrammodellen voor het P-AL- en $\mathrm{P}-\mathrm{CaCl}_{2}$-getal voor de fosfaattoestandsklassen, zoals gedefinieerd in paragraaf 2.2. Hieraan is de klasse 'matig' toegevoegd om volledige dekking van alle fosfaattoestanden te bewerkstelligen (zie hoofdstuk 3). Elk semivariogrammodel geeft de ruimtelijke variatie binnen een perceel weer. Op de y-as staat de semivariantie $(Y)$, op de $x$-as de afstand $(h)$ tussen twee punten in een perceel. Het semivariogrammodel heeft in ons geval drie parameters:

- De nugget-variantie: het punt waar het model de y-as raakt. Deze wordt veroorzaakt door meetfouten en variatie kleiner dan de minimale bemonsteringsafstand.

- De sill-variantie: de maximale semivariantie, een maat voor de variatie binnen het perceel.

- De range: de afstand waarop de curve gaat afvlakken. Dit is een maat voor de ruimtelijke samenhang.

Voor locaties binnen een perceel die dicht bij elkaar liggen (kleine $h$ ), is de semivariantie kleiner dan voor locaties die verder uiteen liggen (grotere $h$ ). Dit komt doordat het P-AL- en P-CaCl${ }_{2}$-getal over het algemeen meer van elkaar zullen verschillen naarmate locaties verder uiteen liggen.

Kijken we naar Figuur 12 en Figuur 13, dan valt op dat niet alle combinaties van P-AL-getal-klasse en $\mathrm{P}-\mathrm{CaCl}_{2}$-getal-klasse zijn gevuld. Op basis van de selectiecriteria in paragraaf 2.2 zouden we verwachten dat in elk van de vier hoekpanelen (linksboven, rechtsboven, linksonder, rechtsonder) een semivariogram voor bouwland en een semivariogram voor grasland beschikbaar is. Dat is echter niet het geval. Alleen het hoekpaneel linksonder (met de extremen P-AL-getal-klasse laag en P-CaCl2klasse hoog) is een semivariogram voor grasland beschikbaar. De overige semivariogrammen zitten in het gebied dat buiten de selectiecriteria viel (dus waar minstens P-AL-getal of P-CaCl${ }_{2}$-getal de klasse 'matig' hebben).

Op grond van deze gegevens kunnen we geen uitspraken doen over het effect van combinaties van hoge en/of lage waarden van het P-AL- of $\mathrm{P}-\mathrm{CaCl}_{2}$-getal op de ruimtelijke variatie binnen het perceel en de gevolgen daarvan op het minimale aantal te nemen steken. Wel zien we dat de variatie binnen percelen veelal groter is voor grasland dan voor bouwland. 


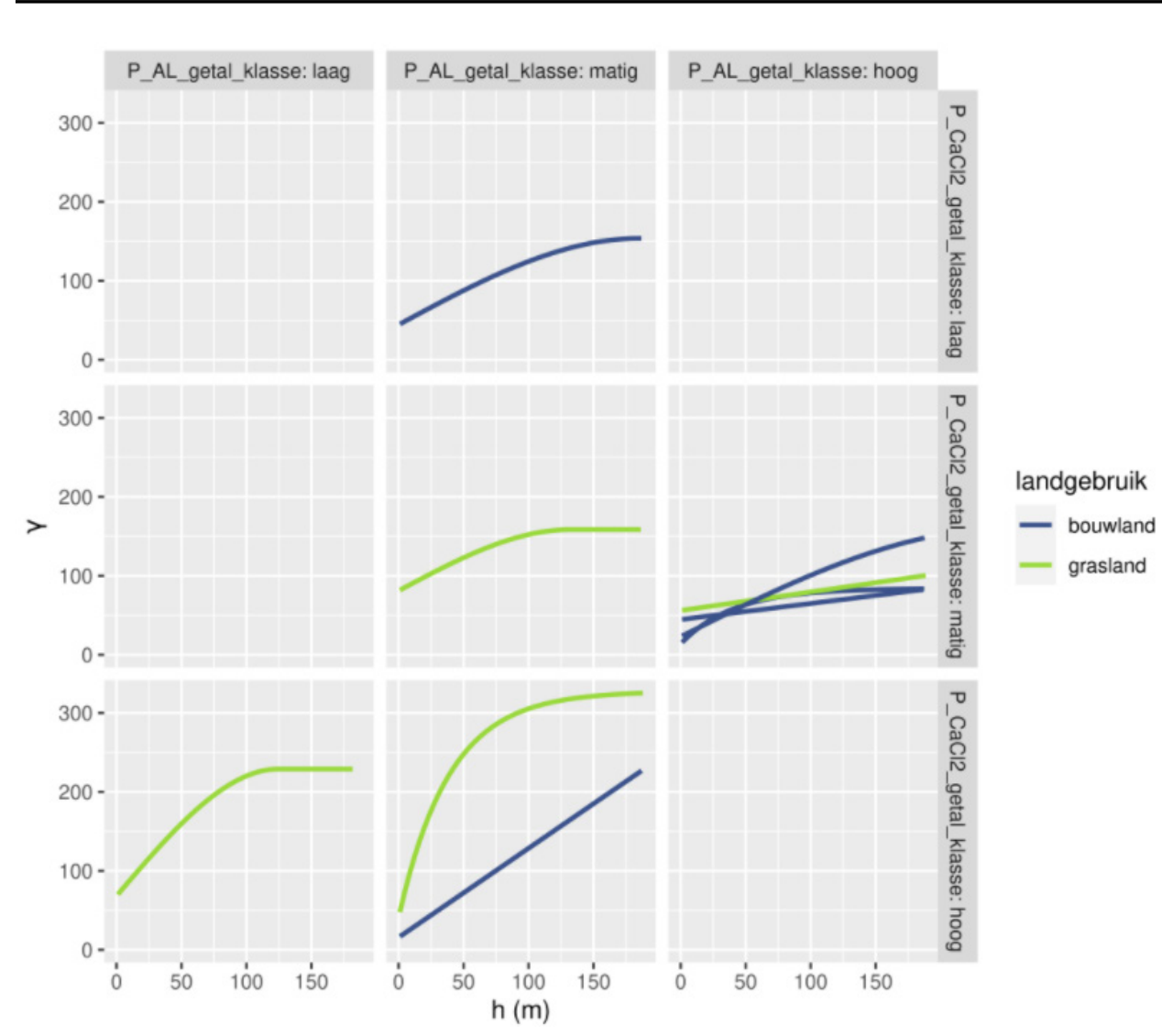

Figuur 12 Semivariogrammodellen voor P-AL-getal voor combinaties van de P-AL-getal-klassen en $P$ - $\mathrm{CaCl}_{2}$ - getal-klassen 'laag', 'matig', en 'hoog'. Op de $Y$-as wordt de semivariantie gegeven, op de $X$-as de afstand tussen de bemonsterpunten. De semivariogrammen zijn gebaseerd op de 9 percelen met elk 50 monsters. Bij de selectie van deze percelen is uitgegaan van vier combinaties, te weten laag-laag, laag-hoog, hoog-laag, hoog-hoog.

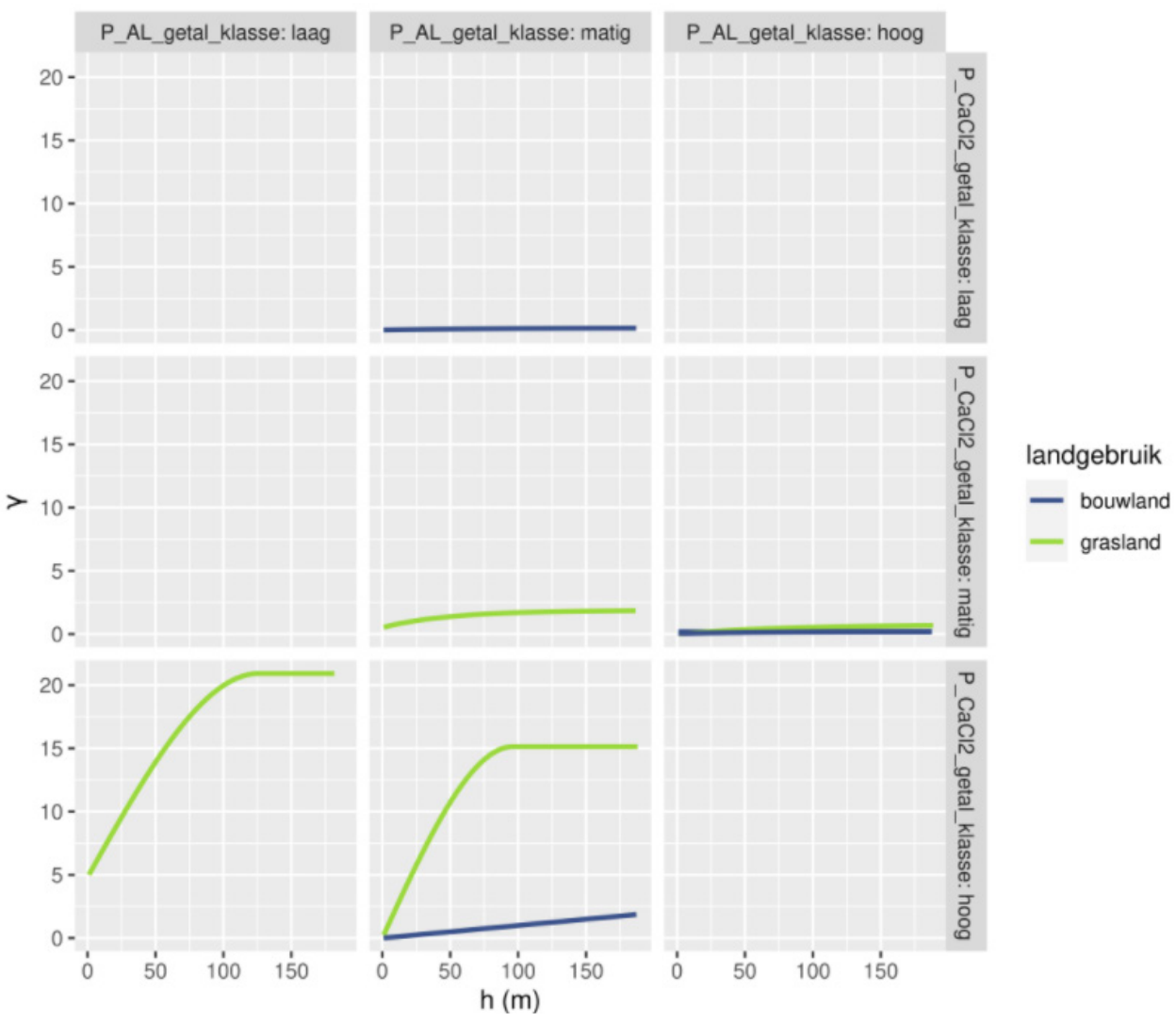

Figuur 13 Semivariogrammodellen voor het $P$ - $\mathrm{CaCl}_{2}$-getal voor combinaties van de $P$-AL-getalklassen en P-CaCl -getalklassen 'laag', 'matig' en 'hoog'. Op de $Y$-as wordt de semivariantie gegeven, op de $X$-as de afstand tussen de bemonsterpunten. 


\section{In het kort}

- In dit onderzoek ontbreken percelen met contrasterende fosfaattoestanden volgens het P-Al- en $\mathrm{P}-\mathrm{CaCl}_{2}$-getal. Bij herbemonstering bleken lage waarden hoger en hogere waarden lager. De herbemonstering leidde tot een groepering van landbouwpercelen met een duiding voor de fosfaattoestand 'matig'.

- Op grond van de beschikbare gegevens, die niet aan het voorgestelde orthogonale ontwerp voldeden, konden we geen verschillen in herhaalbaarheid en reproduceerbaarheid tussen de gestratificeerde aselecte steekproef en de W-methode aantonen. Dat wil echter niet zeggen dat er geen verschillen zijn.

- De vergelijkbaarheid van herhaalbaarheid en reproduceerbaarheid is een gevolg van het ontbreken van de mogelijkheid om variantie te verbinden met een fosfaatklasse. De beoogde contrasten in fosfaattoestanden werden niet bij herbemonstering vastgesteld. Er kunnen verschillen tussen de bemonsteringsstrategieën tussen contrasterende fosfaatklassen aanwezig zijn, maar dat kon met dit onderzoek niet aangetoond worden.

- Herhaling van een bemonstering op eenzelfde tijdstip leidt niet tot eenzelfde waarderingsklasse. In 9 (gestratificeerde methode) en 11 (W-methode) van de 43 percelen wordt een andere waarderingsklasse vastgesteld.

- De landbouwpercelen zijn onder landbouwkundig gebruik, echter de fosfaatbemesting is niet bekend. Herbemonstering is verstrengeld met effecten van fosfaatbemesting. Dit belemmert kwantificering van de reproduceerbaarheid. Er wordt spreiding in het P-AL- en P-CaCl2-getal vastgesteld die niet aan een fosfaatbemestingspraktijk gekoppeld kan worden. Andere bronnen voor temporele en mogelijk ruimtelijke variatie zullen bijgedragen hebben aan de spreiding. Welke dat zijn, is niet eenduidig vast te stellen.

- De nauwkeurigheid van het P-AL-getal bij toepassing van de gestratificeerde steekproef is groter dan die van de $\mathrm{W}$-methode, bij het $\mathrm{P}-\mathrm{CaCl}_{2}$ kon geen verschil in nauwkeurigheid worden aangetoond.

- Doordat de gerealiseerde fosfaattoestand niet overeenkomt met die zoals beoogd volgens de selectiecriteria in paragraaf 2.2, kunnen we geen uitspraken over een eventuele gewenste differentiatie naar fosfaatklasse en de gevolgen daarvan voor de bemonstering. 


\section{Bemonsteringsmethoden in de uitvoeringspraktijk}

In dit hoofdstuk worden de kenmerken van de bemonsteringsmethode volgens een gestratificeerde aselecte steekproef vergeleken met die van de $\mathrm{W}$-methode gelet op de uitvoeringspraktijk. In Figuur 14 wordt een aantal voorbeelden getoond van de W-methode en in Figuur 15 van de gestratificeerde aselecte steekproef. In Bijlage 2 zijn de trajecten die gelopen zijn bij de overige percelen gegeven.
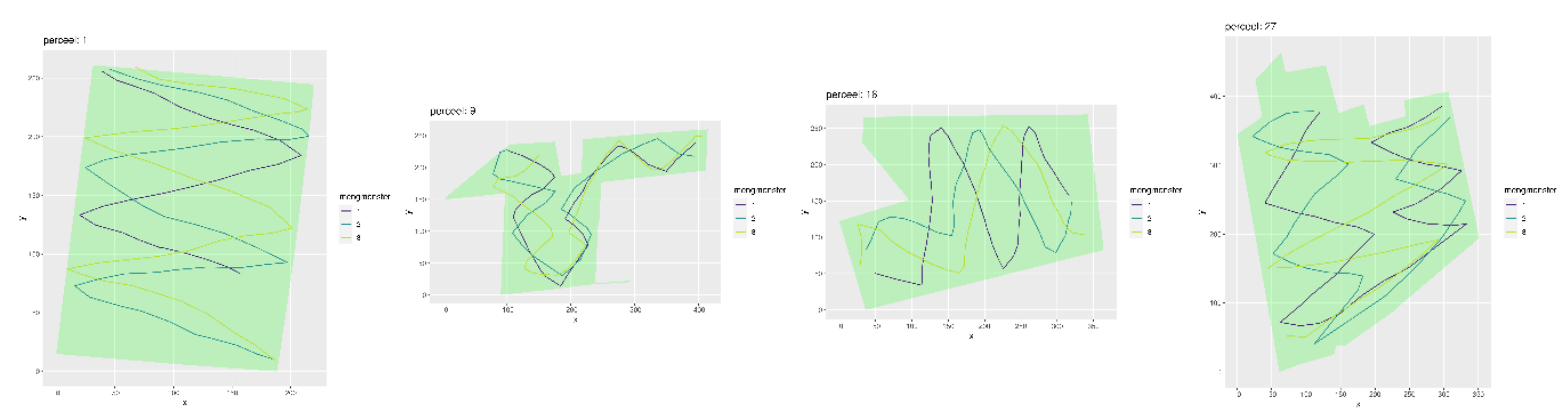

Figuur 14 Vier voorbeelden van de bemonstering van een perceel volgens de W-methode. Het perceel is in groen weergegeven. Daarop zijn de drie trajecten (herhalingen) gesuperponeerd die de monsternemer heeft gevolgd bij het samenstellen van het mengmonster. Percelen 1, 9 en 27 zijn bouwland en perceel 16 is grasland. Dit zijn dezelfde percelen als in Figuren 10 en 11.
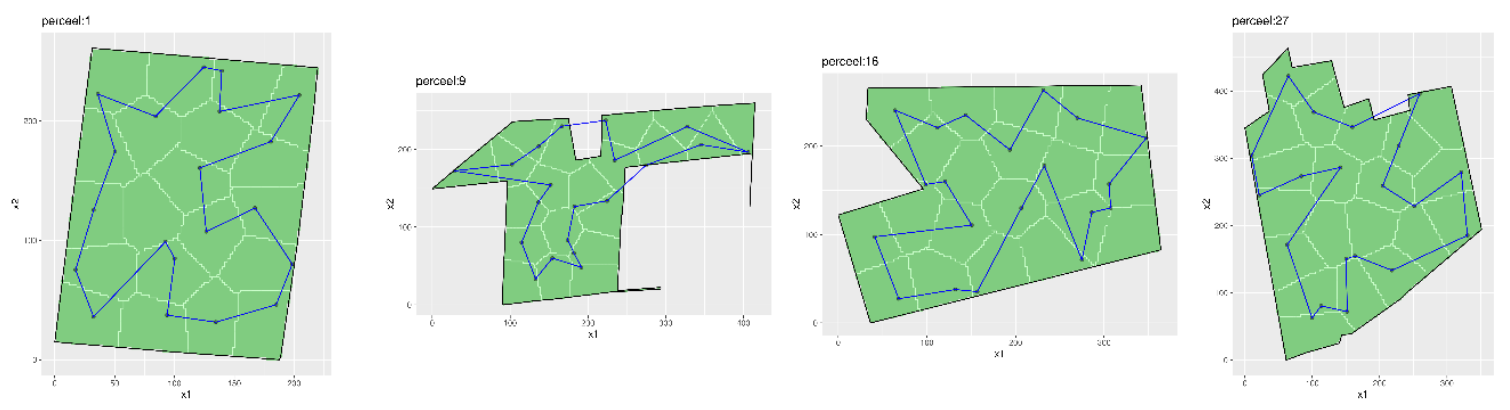

Figuur 15 Vier voorbeelden van de bemonstering van een perceel volgens de gestratificeerde steekproef. Het perceel is in groen weergegeven. Daarop is een voorbeeld van traject gesuperponeerd die de monsternemer heeft gevolgd bij het samenstellen van het mengmonster. De twintig polygonen zijn de compacte en even grote geostrata. Percelen 1, 9 en 27 zijn bouwland en perceel 16 is grasland. Dit zijn dezelfde percelen als in Figuren 10 en 11.

Bijlage 1 geeft het overzicht van alle 43 percelen. De lijnen geven de trajecten die de monsternemers hebben gelopen, de punten de locaties waar de steken zijn genomen. De polygonen in de onderste figuur zijn de compacte en even grote geostrata.

De monsterpunten zijn zowel bij de gestratificeerde aselecte steekproef als bij de W-methode met gps-coördinaten vastgelegd. Daardoor is bekend welke delen van een perceel zijn bemonsterd en welke delen niet.

Bij de gestratificeerde aselecte steekproef worden de locaties waar bodemmonsters moeten worden gestoken, uitgerekend met behulp van een computeralgoritme (Brus et al., 1999; Walvoort et al., 2010). Een perceel wordt daarbij eerst opgedeeld in compacte stukken die even groot zijn. Die worden geostrata genoemd. Vervolgens wordt binnen elk geostratum een willekeurige locatie geloot waar een steek wordt genomen. Elke locatie binnen een perceel heeft hierdoor een even grote kans om te 
worden geselecteerd. Er worden geen locaties uitgesloten of preferent bemonsterd. De steken worden samengevoegd tot een mengmonster. Dat mengmonster wordt vervolgens geanalyseerd in het laboratorium. Doordat elke locatie een even grote kans heeft om te worden geselecteerd, is het mengmonster een zuivere afspiegeling van de ruimtelijke variatie van het P-AL-getal en het $\mathrm{CaCl}_{2}-$ getal binnen het perceel.

Bij de W-methode wordt een W-vormig traject gelopen waarlangs steken worden verzameld. Dit traject wordt door de monsternemer zelf bepaald. Ook de locaties waar de steken gestoken moeten worden langs het traject liggen niet op voorhand vast en worden tijdens de monsterneming bepaald. Het gevolg is dat niet elk punt in het perceel een even grote kans heeft om gestoken te worden. Dat blijkt ook uit Figuur 14. Elke figuur laat een perceel zien (groen) met drie W-vormige trajecten. Bij perceel 1 zie je dat het eerste traject niet volledig is afgerond. De W is hier een Z. Het mengmonster is hierdoor geen afspiegeling van het zuidelijke deel van het perceel. Als de gehalten in het zuidelijke deel van het perceel afwijken van die in de rest van het perceel, resulteert dit in een systematische fout van de fosfaattoestand. Een ander voorbeeld is perceel 9. Dit is een perceel met een complexe vorm. Dat maakt het lastig om een $\mathrm{W}$ uit te zetten. We zien daardoor dat de monsternemers de hoeken van het perceel missen. Ook zien we dat de eerste twee trajecten preferent de randen van het centrale deel lijken te volgen. Bij perceel 16 zien we ook dat hoeken worden overgeslagen. Bij perceel 27 zien we dat de eerste twee trajecten langs de randen van het perceel zijn uitgezet, terwijl het derde traject een brede zigzag-vorm heeft. Het noordelijke deel van dit perceel is buiten beschouwing gebleven (de reden is niet bekend, hier zou een wendakker kunnen liggen).

We zien dus dat de mate waarin het mengmonster een afspiegeling van het perceelgemiddelde is bij de W-methode wordt bepaald door enerzijds de voorkeuren en/of praktijkinzichten van de monsternemer en anderzijds door de vorm van het perceel. De W-methode zal hierdoor leiden tot een onbekende systematische fout. Deze zal gemiddeld genomen over percelen mogelijk klein zijn, maar kan voor individuele percelen aanzienlijk zijn. De grootte van de systematische fout hangt af van het ruimtelijke patroon van de fosfaatparameter. Bij de gestratificeerde aselecte steekproef is dat niet het geval. Daar zorgt het computeralgoritme ervoor dat alle locaties binnen het perceel een even grote kans maken om geselecteerd te worden voor bemonstering.

Tot slot is ook het aantal steken niet gelijk voor de twee bemonsteringsmethoden. Bij de gestratificeerde aselecte steekproef wordt het aantal steken van tevoren opgelegd. Het computerprogramma zorgt er dan voor dat er net zoveel compacte en even grote geostrata worden gevormd als er steken moeten worden genomen. Bij de W-methode lijkt het aantal steken te worden bepaald door de monsternemer. Dit zouden er veertig moeten zijn. Figuur 16 geeft het aantal steken weer als functie van de perceelgrootte. Deze figuur is geconstrueerd op basis van gps-coördinaten (way-points) die door Eurofins Agro zijn aangeleverd. De aanname is dan ook dat elk way-point correspondeert met een steek. Of dat klopt, is achteraf niet vast te stellen. De monsternemer kan immers vergeten zijn om een way-point in te voeren bij het steken. Ook kan het zijn dat way-points automatisch worden opgeslagen (als functie van tijd of afstand). Overige oorzaken zouden kunnen zijn dat de monsternemer vergeten is om de gps aan te zetten. In dat geval wordt het aantal steken te laag aangegeven. Bijlage $L$ van de uitvoeringsregeling Meststoffenwet schrijft voor dat maximaal 5 ha bemonsterd mag worden en dan 40 submonsters gestoken moeten worden van elk een gelijk volume. Is het perceel groter, dan wordt in de uitvoeringspraktijk het perceel opgedeeld in twee blokken en neemt het aantal steken evenredig toe met het areaal. In dit onderzoek zijn, ongeachte de grootte van het areaal, telkens 40 steken genomen.

We zien een grote variatie in aantallen steken bij de W-methode. De bulk van de steken lijkt rond de 40 te zitten (hetgeen verwacht mag worden), maar er zijn ook uitschieters naar onderen $(<10)$ en naar boven (60). Er is echter geen relatie tussen het aantal steken en de grootte van het perceel. Doordat mengmonsters gebaseerd zijn op een variabel aantal steken, zal de mate waarin het mengmonster een afspiegeling is van het perceelgemiddelde ook wisselen. 


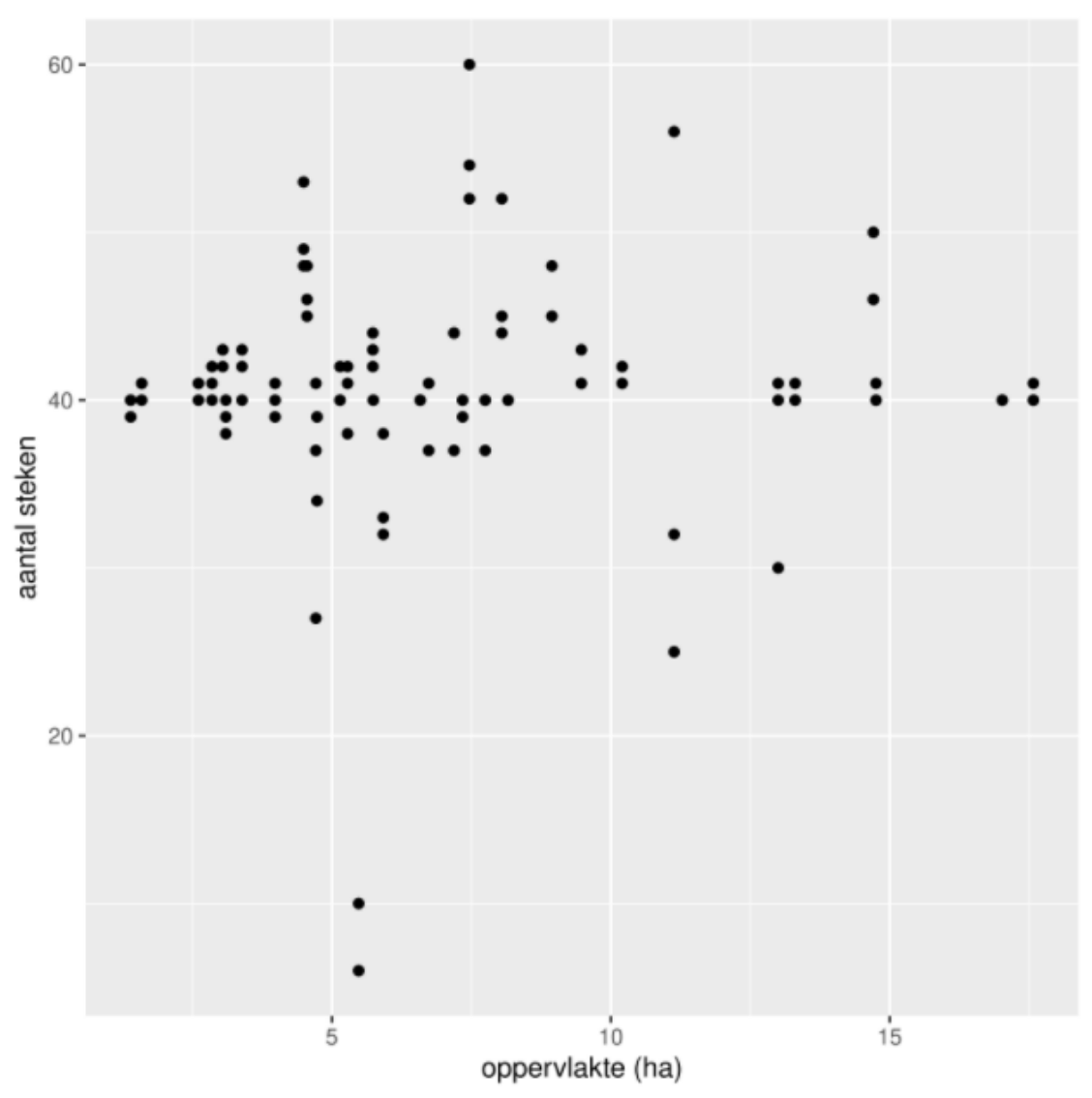

Figuur 16 Aantal steken bij de W-methode als functie van de perceelgrootte zoals afgelezen uit de way-points die met de gps zijn geregistreerd.

\section{In het kort}

In Tabel 3 zijn de verschillen tussen de gestratificeerde aselecte steekproef en de W-methode samengevat. Deze tabel is opgesteld onder de veronderstelling dat elke steek eenzelfde hoeveelheid grond bemonstert en monsterpunten niet worden gemeden. Monsterpunten kunnen worden gemeden in geval van bijvoorbeeld een mestflat of een rijspoor.

Tabel 3 Verschillen tussen de gestratificeerde aselecte steekproef en de W-methode.

\section{Gestratificeerde aselecte steekproef}

Elke locatie binnen een perceel heeft een even grote kans om te worden bemonsterd.

\section{W-methode}

De kans op bemonstering hangt af van de monsternemer en de vorm van het perceel en is niet bekend. Uit de praktijkvoorbeelden (Figuur 14) is gebleken dat delen van het perceel onbewust worden uitgesloten van bemonstering.

Statistische eigenschappen van de bemonstering zijn bekend (systematische fout $(=0)$ en willekeurige fout is Statistische eigenschappen zijn onbekend. Onbekende systematische fout.

afhankelijk van de variatie in het perceel). Deze

eigenschappen kunnen bovendien worden

gekwantificeerd.

Bemonstering is objectief (De locaties van de steken worden bepaald door wetenschappelijke software).

Bemonstering is deels subjectief (de monsternemer bepaalt de locaties van de steken).

Wetenschappelijke basis Praktijkervaring, expert judgement

Minimaal benodigde aantal steken voor een mengmonster Minimaal benodigde aantal steken is lastig te bepalen. Daar kan worden bepaald o.b.v. een geostatistische analyse. zijn aannames voor nodig.

Mengmonster heeft betrekking op het hele perceel. Mengmonster heeft betrekking op de selecteerde punten.

Een computer bepaalt de locatie van de steken. Een monsternemer bepaalt de locatie van de steken.

Voor het nemen van steken is gps nodig. Voor het nemen van steken is geen gps nodig.

Toepasbaar op percelen met uiteenlopende vormen. Lastig uit te voeren bij percelen met een complexe vorm (zie Figuur 14). 


\section{$6 \quad$ Evaluaties en conclusies}

\subsection{Evaluatie \& conclusies}

Het onderzoek werd uitgevoerd op praktijkpercelen op grasland en bouwland. Aanvankelijk werd beoogd om vier contrasterende fosfaatklassen laag/laag, laag/hoog, hoog/laag en hoog/hoog in het onderzoek op te nemen. Hierdoor worden de patronen in de data beter zichtbaar en zijn die ook beter te modelleren. Bij de selectie werd vastgesteld dat de criteria voor het P-AL-getal aangepast dienden te worden om tot het gewenste aantal percelen te komen. Bovendien werden bij herbemonstering en heranalyse van de percelen andere fosfaattoestanden vastgesteld dan die waarop de selectie berustte. Het oorspronkelijke orthogonale ontwerp van de steekproeven met de twee bemonsteringsstrategieën werd daardoor gewijzigd naar een observationele statistische analyse. Hierdoor ontbreekt de basis om voor fosfaat-fixerende en fosfaatarme landbouwpercelen te onderzoeken of de gestratificeerde aselecte steekproef bij invoering van een gecombineerde indicator voor de bepaling van de fosfaattoestand aanpassing vergt. Bij herbemonstering bleek ten opzichte van de selectie de toestand laag hoger te zijn en de toestand hoog lager. Feitelijk vielen de fosfaattoestanden buiten de beoogde contrasterende fosfaatklassen (Tabel 4) en clusterde rond fosfaattoestanden die wij in deze rapportage als 'matig' hebben geïdentificeerd.

We berekenen voor grasland hogere waarden voor het aantal te nemen steken en voor bouwland lagere. In vergelijking met het aantal benodigde steken vermeld in Ehlert et al. (2005) zijn het hogere aantallen. Dit berust op de nieuwe metingen waardoor andere semivariogrammodellen verkregen worden om de steekproeffout te berekenen. Het hogere aantal steken wordt veroorzaakt doordat in het huidige onderzoek fosfaatarme gronden ontbreken en we vooral te maken hebben met percelen met hogere fosfaattoestanden.

In 2005 was een semivariogrammodel geselecteerd voor een perceel met een lage fosfaattoestand. In onze studie kan niet gedifferentieerd worden naar fosfaattoestand. Dit komt doordat het oorspronkelijke ontwerp met contrasterende fosfaatklassen niet kon worden gerealiseerd.

De huidige resultaten bevestigen de resultaten van het onderzoek in 2005, namelijk dat het aantal steken toeneemt bij toename van de grootte van het areaal. Deze toename is echter niet evenredig met de grootte van het areaal van een landbouwperceel. Indien een graslandperceel van 10 ha naar 20 ha toeneemt, dan neemt het aantal te nemen steken toe van 29 naar 33.

Herhaalbaarheid van de gestratificeerde aselecte steekproef en de W-methode zijn onderling vergelijkbaar, gegeven de conditie dat de verzamelde data niet beantwoordden aan het voorgestelde orthogonale ontwerp. $\mathrm{Er}$ is ook geen systematisch verschil aantoonbaar tussen grasland en bouwland tussen de twee bemonsteringsstrategieën.

De landbouwpercelen zijn onder landbouwkundig gebruik en zijn naar verwachting bemest met fosfaat. De fosfaatgiften zijn niet bekend. Residuen van fosfaatbemesting hebben een effect op de fosfaattoestand: die wordt gehandhaafd of neemt toe. Vastgesteld wordt dat er ook daling optreedt in een mate die niet redelijkerwijs aan residueffecten van fosfaatmeststof of aan het ontbreken van fosfaatbemesting kunnen worden toegeschreven. Dit belemmert kwantificering van de reproduceerbaarheid.

De nauwkeurigheid voor het P-AL-getal is significant $(p<0.001)$ hoger voor de stratificeerde steekproef dan voor de $\mathrm{W}$-methode. Voor het $\mathrm{P}$ - $\mathrm{CaCl}_{2}$-getal kon geen significant verschil in nauwkeurigheid tussen de twee methoden worden aangetoond. Het mediane verschil in RMSE is berekend op 0,87 mg $\mathrm{P}_{2} \mathrm{O}_{5} / 100 \mathrm{~g}$. Deze mediaan heeft gemiddeld genomen geen wezenlijk effect op de plaatsing in een fosfaatklasse. De spreiding per individueel perceel is aanzienlijk (Figuur 9). Individuele percelen kunnen wel in een andere fosfaatklasse geplaatst worden (een hogere of een lagere). 
Er zijn verschillen in kenmerken tussen de twee bemonsteringsmethoden. De gestratificeerde aselecte steekproef is wetenschappelijk onderbouwd, objectief en toepasbaar op percelen met uiteenlopende vormen, de W-methode berust meer op praktijkervaring.

In Bijlage $L$ van de Uitvoeringsregeling Meststoffenwet (URMW) wordt voor een bemonsteringsprotocol gebaseerd op de W-methode, de zig-zag-methode of kruislingse bemonstering een maximale omvang van 5 ha opgelegd waar eventueel aan elkaar grenzende percelen mogen worden samengevoegd tot een totale omvang van ten hoogste 5 ha. De omvang van de individuele percelen mag niet groter zijn dan 2,5 ha.

Voor de gestratificeerde aselecte steekproef is een protocol beschikbaar. Bijlage $C$ van de Uitvoeringsregeling Meststoffenwet geeft het protocol. Dit is gebaseerd op Ehlert et al. (2005). Aanpassingen van het protocol worden voorgesteld in hoofdstuk 7.

Bijlage $L$ van de Uitvoeringsregeling Meststoffenwet stelt voorwaarden aan in-huis-protocollen van geaccrediteerde laboratoria. Deze in-huis-protocollen zijn niet beschikbaar in het publieke domein. Een interne publicatie, opvraagbaar bij Eurofins Agro, is verstrekt ter karakterisering van de W-methode. Dit rapport van Termorshuizen (2009) geeft resultaten van een modelstudie. Op ons verzoek voor een protocol voor de W-methode is gereageerd met de studie van Aad Tremorshuizen uit 2009. Deze modelstudie geeft echter geen protocol. Deze modelstudie concludeert dat de W-methode ten opzichte van andere bemonsteringsmethode waaronder een blokbemonstering vergelijkbaar presteert en komt daarmee qua uitsluitsel overeen met het resultaat van deze studie die gebaseerd is op metingen. De blokbemonstering gebaseerd op rechthoekige blokken benadert de gestratificeerde methode gebaseerd op even grote vierkante blokken.

De modelstudie van Termorshuizen uit 2009 onderbouwt een uitvoering die al sinds jaar en dag in de landbouwuitvoeringspraktijk wordt toegepast. In 1979 publiceerden Ris en Wolf (1979) een nota waarin de standaardafwijking als functie van het aantal steken werd gegeven. De standaardafwijking nam bij minder dan 20 steken fors toe, maar daalde nauwelijks bij verhoging van het aantal steken van 29 naar 40 steken voor het Pw- en P-AL-getal. Ris en Wolf (1979) baseerden zich op meetgegevens van een kleigrond in Oude Schans, een lössgrond in Wijnandsrade, een oude dalgrond in Borgercompagnie en een venige zandgrond in Giethoorn. Het voorschrift voor 40 steken per perceel is feitelijk gebaseerd op onderzoek van Ferrari \& Vermeulen (1955 \& 1956). Dit voorschrift is deels gebaseerd op theorie en deels op pragmatisme. Met 40 steken werd de monsterzak met circa $1 \mathrm{~kg}$ grond gevuld.

Deze studie wijst uit dat herhaalbaarheid en reproduceerbaarheid van een gestratificeerde aselecte steekproef en van de W-methode vergelijkbaar zijn. Dit geldt onder de conditie van fosfaattoestanden die wij in dit rapport als 'matig' hebben gedefinieerd. Deze studie kan geen uitsluitsel geven over de vergelijking van het bemonsteringsprotocollen voor fosfaat-fixerende en fosfaatarme landbouwgronden. Een basis ontbreekt om het protocol voor het aanwijzen van fosfaat-fixerende gronden te wijzigingen.

Indien gekozen wordt voor een generieke benadering en gefocust wordt op meer gangbare fosfaattoestanden, dan kan een wijzigingsvoorstel gegeven worden (hoofdstuk 7). Een overzicht voor 2019 opgesteld door het CBS (2020) wijst uit dat 34\% van het aantal graslandpercelen en $45 \%$ van het aantal bouwlandpercelen geen meting hebben van de fosfaattoestand. Deze percelen hebben daardoor de fosfaattoestand hoog toegewezen gekregen (defaultwaarde als geen metingen beschikbaar zijn). Percelen met de fosfaattoestand arm vertegenwoordigen in de populatie van gemeten fosfaattoestanden op grasland $5,7 \%$ en op bouwland $17,1 \%$ van de metingen. Fosfaatfixerende gronden en fosfaatarme gronden worden aangemerkt als laag. Deze percelen komen relatief weinig voor. Bij invoering van een fosfaatgebruiksnormenstelsel gebaseerd op de gecombineerde indicator worden de contrasten in fosfaatgiften minder groot. Het relatief lage aandeel in de klasse arm en het verminderde contrast in fosfaatgebruiksnorm tussen klasse laag en arm kunnen argumenten zijn voor een generiekere benadering. 


\subsection{Aanbevelingen}

\subsubsection{Beslissen in onzekerheid}

Het P-AL- en het P-CaCl2-getal kunnen nooit foutloos worden bepaald. Dat komt door de steekproeffout ten gevolge van de ruimtelijke variatie binnen het perceel, eventuele bemonsteringsfouten en de laboratoriumfout. Hierdoor zijn we ook onzeker over de fosfaattoestand die op grond van deze indicatoren wordt afgeleid. We bevelen daarom aan om een methode vergelijkbaar met die beschreven in Ehlert et al. (2005, p.18 en p.90) toe te passen, waarbij met deze onzekerheid expliciet rekening wordt gehouden. Een voorzet wordt gegeven in het protocol in hoofdstuk 7. Aanbevolen wordt om na te gaan in hoeverre we deze methode kunnen verfijnen op basis van de gegevens die zijn verzameld in het kader van het huidige project.

\subsubsection{Training}

Voor het op juiste wijze toepassen van de gestratificeerde aselecte steekproef en de W-methode wordt aanbevolen om de monsternemers een korte training te geven. Tijdens die training zouden niet alleen de protocollen moeten worden doorlopen, maar tevens de noodzaak van elke handeling moeten worden uitgelegd. Onze ervaring is dat dit het draagvlak van en het begrip voor een bemonsteringsmethode vergroot.

Een training moet bijvoorbeeld voorkomen dat bij de W-methode te veel of juist te weinig steken worden genomen omdat onvoldoende (of geen) rekening wordt gehouden met de grootte van het perceel (zie hoofdstuk 5, Figuur 14).

Bij de gestratificeerde aselecte steekproef zou moeten worden benadrukt dat steken moeten worden genomen op de locaties die door de computer zijn geselecteerd. Mocht een locatie buiten het perceel vallen of niet te bemonsteren zijn (betonplaat o.i.d.), dan dient men gebruik te maken van een reservepunt dat verkregen wordt door opnieuw te loten.

Het uitvoeren van de gestratificeerde aselecte steekproef kan verder worden vereenvoudigd door een computer de kortste route langs de te steken locaties te laten berekenen. Dit is bijvoorbeeld gedaan in Figuur 15 (blauwe lijn). 


\section{$7 \quad$ Protocol}

\subsection{Leeswijzer}

Deze studie wijst uit dat we geen verschillen kunnen aantonen wat betreft herhaalbaarheid en reproduceerbaarheid van een gestratificeerde aselecte steekproef en van de W-methode. Dit geldt onder de conditie van fosfaattoestanden die wij in dit rapport als 'matig' hebben gedefinieerd. Deze studie kan geen uitsluitsel geven over de vergelijking van het bemonsteringsprotocollen voor fosfaatfixerende en fosfaatarme landbouwgronden, oftewel landbouwpercelen die in de fosfaatklasse arm vallen. In dit hoofdstuk wordt een voorstelwijziging van het protocol voor de gestratificeerde aselecte steekproef gegeven indien een generieke benadering wordt gevolgd.

\subsection{Gestratificeerde aselecte steekproef}

In deze paragraaf wordt een concept van het bemonsteringsprotocol gegeven. In feite betreft het een aanpassing van het protocol dat door Ehlert et al. (2005) werd gegeven voor toepassing van een gestratificeerde aselecte steekproef voor bouwland (Pw-getal) of grasland (P-AL-getal) voor fosfaatarme en/of fosfaat-fixerende landbouwgronden. Het hier gegeven protocol is gebaseerd op de grondslag dat de gecombineerde indicator door meting van het $\mathrm{P}-\mathrm{CaCl}_{2}$ - en $\mathrm{P}$-AL-getal rekening houdt met het bufferend vermogen van de bodem. Het bemonsteringsprotocol volgt Bijlage $C$ van de Uitvoeringsregeling Meststoffenwet. Aanpassingen betreffen de opname van de gecombineerde bodemindicator voor de bepaling van de fosfaattoestand van een landbouwperceel.

\subsubsection{Wijzigingen}

Hier zullen de veranderingen worden aangegeven ten opzichte van een vorige versie van het voorschrift.

\section{Doel}

Het protocol is erop gericht om de fosfaattoestand van landbouwpercelen te bepalen. Het protocol beschrijft het nemen van een representatief grondmonster en de methoden van chemisch grondonderzoek. Op basis daarvan dient uiteindelijk vastgesteld te worden of de fosfaattoestand zodanig laag is dat het perceel landbouwgrond in aanmerking komt voor een verhoogde gebruiksnorm.

\section{Principe}

De bouwvoor of zode van een perceel landbouwgrond wordt volgens een gestratificeerde aselecte steekproef bemonsterd. De strata worden gevormd door even grote, zo compact mogelijke blokken, zodat de bemonsteringspunten zo goed mogelijk worden verdeeld over het perceel. Op elk bemonsteringspunt wordt grond bemonsterd van de voorgeschreven bodemlaag. De hoeveelheid (volume) gestoken grond is gelijk voor alle bemonsteringspunten. De grond van de verschillende bemonsteringspunten wordt verzameld tot één mengmonster. Het mengmonster wordt volgens voorgeschreven methoden van grondonderzoek voorbehandeld en in duplo geanalyseerd op fosfaattoestand volgens aangewezen methoden van grondonderzoek. De resultaten van het chemisch grondonderzoek worden vervolgens getoetst aan een beoordelingskader. Het resultaat van toetsing wordt vastgelegd.

Het resultaat van opvolgen van het protocol is dat, indien aan de criteria en de zorgvuldigheidswaarborgen wordt voldaan, wetenschappelijk verantwoord wordt vastgesteld of een perceel landbouwgrond in aanmerking komt voor een verhoogde gebruiksnorm.

Het protocol geeft uitsluitsel of een verhoogde gebruiksnorm toegestaan kan worden. 


\section{Toepassingsgebied}

Het protocol is van toepassing voor percelen landbouwgrond die in aanmerking komen voor een verhoogde gebruiksnorm indien beantwoord wordt aan een criterium voor de rubricering in de fosfaatklasse arm.

\section{Definities}

\section{Fosfaatklasse}

Waardering van de fosfaattoestand op basis van het $\mathrm{P}-\mathrm{CaCl}_{2}$ - en $\mathrm{P}$-AL-getal volgens een bij ministeriële regeling vastgestelde toetsingswaarde. Waarderingsklassen zijn arm, laag, voldoende, ruim en hoog. Percelen met de waardering arm komen in aanmerking voor een verruimde gebruiksnorm.

\section{Fosfaattoestand}

De hoeveelheid fosfaat in de bouwvoor of zode, bepaald door bij ministeriële regeling aangewezen methoden van grondonderzoek.

\section{Perceel}

Topografische eenheid landbouwgrond: aaneengesloten, door wegen, waterwegen, sloten, houtopstanden, muren, wallen of anderszins topografisch begrensde oppervlakte grond, dan wel het gedeelte daarvan behorend tot één bedrijf (artikel 16., UBMW ${ }^{12}$ ).

\section{Landbouwgrond}

Conform $\mathrm{MW}^{13}$ : grond in gebruik als grasland of bouwland conform ministeriële regelingen in het kader van de Meststoffenwet.

\section{Gestratificeerde aselecte steekproef}

Steekproefopzet waarbij het perceel landbouwgrond in $n$ ( $n=$ aantal bemonsteringspunten) even grote, zo compact mogelijke geografische blokken (strata) wordt onderverdeeld en uit elk blok volledig aselect één bemonsteringspunt wordt gekozen.

\section{Toetsingswaarde}

Een getalsmatig uitgedrukte waarde voor de fosfaattoestanden waarboven het perceel niet in aanmerking komt voor verhoging van de gebruiksnorm.

\section{Bemonstering van het perceel landbouwgrond}

Bemonsteren van door de gestratificeerde aselecte steekproef aangewezen bemonsteringspunten.

\section{Verwijzingen}

\section{Verwijzing naar andere protocollen}

De onderstaande andere protocollen zijn van toepassing:

- Voor de keuze van de boor voor bemonsteren van de bodemlagen 0-10 cm voor grasland of 0-25 cm voor bouwland.

Alleen de onderdelen die betrekking hebben op de bemonstering van de genoemde bodemlagen zijn relevant.

NPR 5741:2015 $\mathrm{nl}$ - Bodem - Richtlijn voor de keuze en toepassing van boortechnieken en monsternemingstoestellen voor grond, sediment, slib en grondwater bij milieuonderzoek

ISO 11464:2006 en Bodem - Voorbehandeling van monsters voor fysisch-chemische analyses. Nederlands Normalisatie Instituut, Delft

\footnotetext{
12 UBMW: Uitvoeringsbesluit Meststoffenwet

${ }^{13} \mathrm{MW}$ : Meststoffenwet
} 
NEN 5704:1996. Bodem - Monstervoorbehandeling van grond - Extractie met een calciumchlorideoplossing $(0,01 \mathrm{~mol} / \mathrm{l})$. Nederlands Normalisatie Instituut, Delft

NEN 5793 Bodem. De bepaling van fosfaat in grond extraheerbaar met een ammoniumlactaatazijnzuur buffer (P-AL)'. Nederlands Normalisatie Instituut, Delft

NEN-ISO 15923-1:2013 en. Waterkwaliteit - Bepaling van de ionen met een discreet analysesysteem en spectrofotometrische detectie - Deel 1: Ammonium, chloride, nitraat, nitriet, ortho-fosfaat, silicaat en sulfaat). Nederlands Normalisatie Instituut, Delft

- NEN 5704 en NEN 5793 geven de extractiemethoden. Deze extracties vormen de kern van de uitvoering van het protocol voor het aanwijzen van gronden die fosfaatarm zijn. Daarnaast geven de protocollen het principe van de meting van fosfor in het extract. Dit principe is gebaseerd op de klassieke colorimetrische bepalingsmethode. De essentie van de bepaling van fosfaat van het Pw-getal wordt gevormd door de analysemethode van Murphy \& Riley (1962). De fosfaatbepaling in de extracten berusten op een fotometrische bepaling volgens de molybdeenblauw-methode. Die vinden toepassing bij doorstroomanalysesystemen of doorstroominjectiesystemen.

\section{Verwijzing naar andere normstellende documenten}

Het toepassen van dit protocol dient uitgevoerd te worden door een organisatie (rechtspersoon) die aantoonbaar beschikt over - en voldoet aan - een geaccrediteerde vorm van kwaliteitszorg ISO-9001. De voorbehandeling en de fysisch-chemische analyses dienen uitgevoerd te worden door een geaccrediteerd laboratorium (ISO 17025).

\section{Benodigdheden}

\section{Apparatuur}

De benodigde apparatuur bestaat uit:

- GNNS

- Veldcomputer voorzien van software om het perceel landbouwgrond te verrasteren en de bemonsteringsplekken te loten.

\section{Hulpmiddelen}

Hulpmiddelen zijn:

- Top-10 vectorkaart (TOP10NL)

- Steekguts of edelmanboor met een voorgeschreven minimale grootte voor de verzameling van de voorgeschreven minimale hoeveelheid grond.

- Duimspatel

- Verpakkingsmateriaal: plastic zakken of papieren zakken met een polyethyleen bekleding.

- Etiketten

\section{Werkwijze}

\section{Bemonstering van het perceel landbouwgrond}

- Markeer de vormbepalende hoekpunten. Zoek het perceel op een Top-10 vectorkaart (TOP10NL).

- Registreer het landgebruik: gras- of bouwland.

- Bepaal de bemonsteringsdiepte op basis van het landgebruik. Op grasland is de bemonsteringsdiepte $10 \mathrm{~cm}$, op bouwland $25 \mathrm{~cm}$.

- Controleer en verifieer de gps-data met de Top-10 vectorkaart. Dit geldt indien er nog geen kaarten beschikbaar zijn.

- Bepaal de grootte van het perceel. Bepaal volgens Tabel 4 het aantal blokken dat gelijk is aan het benodigde aantal bemonsteringspunten. Verdeel vervolgens het perceel landbouwgrond in het hiervoor bepaalde aantal blokken. De blokken dienen even groot en zo compact mogelijk te zijn. Deze onderverdeling van het perceel in blokken (stratificatie) wordt uitgevoerd met een softwareprogramma.

- Selecteer per blok volledig aselect (met een computer) één bemonsteringspunt. Lokaliseer deze punten met gps en gebruik daarvoor zo nodig de Top-10 vectorkaart. 
- Ga met gps naar het geselecteerde bemonsteringspunt.

- Indien een gelokaliseerd bemonsteringspunt buiten het perceel valt, loot dan een nieuw punt binnen hetzelfde geostratum.

- Selecteer een geschikte boor om de grondmonstername mee uit te voeren. Raadpleeg hiervoor indien nodig NPR 5741:2015 nl.

- Mijd resten van (dierlijke) meststoffen of reststoffen. Het is toegestaan om $5 \mathrm{~m}$ af te wijken van het geselecteerde bemonsteringspunt om contaminatie met mest- en reststoffen te vermijden.

- Zorg ervoor dat de te gebruiken boor grondig is gereinigd alvorens deze wordt gebruikt. Grondresten van een ander perceel dienen afwezig te zijn.

- Bemonster met een geschikte boor grond tot $10 \mathrm{~cm}$ diepte op grasland en $25 \mathrm{~cm}$ diepte op bouwland. Tot de aangegeven diepte dient de boor volledig met grond gevuld te zijn.

- Trek de boor met grond uit de bodem en breng m.b.v. de bijbehorende duimspatel de grond over in een stevige plastic zak of een papieren zak met polyethyleen bekleding.

- Verzamel op deze wijze grond op alle $n$ bemonsteringspunten en breng dit samen in een zak. De booromvang dient zo groot te zijn dat het mengmonster minimaal $1 \mathrm{~kg}$ weegt. Per steek dient minimaal circa $50 \mathrm{~g}$ grond te worden bemonsterd. Meestal volstaat een gutsboor. De omvang van het grondmonster van $n$ bemonsteringspunten dient niet te groot te zijn, sub-bemonstering in het veld dient te worden uitgesloten. Eventueel wordt op een bemonsteringspunt tweemaal een monster gestoken om de minimale hoeveelheid grond te verzamelen, maar dit dient dan op alle bemonsteringspunten te gebeuren. De bemonsteringspunten dienen maximaal $1 \mathrm{~m}$ van elkaar verwijderd te liggen binnen hetzelfde blok. Op alle bemonsteringspunten dient evenveel grond te worden verzameld!

- Bewaar het grondmonster in niet-luchtdicht afgesloten plastic zakken bij $0-4{ }^{\circ} \mathrm{C}$ in het donker.

- Breng de grondmonsters over naar het laboratorium voor verdere behandeling.

- De maximum bewaartijd is onder deze condities op drie maanden vastgesteld.

Tabel 4 Het benodigde aantal bemonsteringspunten als functie van het areaal van het perceel landbouwgrond.

\begin{tabular}{lll} 
& \multicolumn{2}{l}{ Aantal bemonsteringspunten } \\
\cline { 2 - 3 } Oppervlakte perceel & Grasland & Bouwland \\
\hline 1-5 ha & 25 & 25 \\
\hline $5-10$ ha & 29 & 28 \\
\hline $10-20$ ha & 33 & 32 \\
\hline$>20$ ha & 37 & 38 \\
\hline
\end{tabular}

\section{Voorbehandeling van de grondmonsters}

Behandel het grondmonster voor volgens ISO 11464:2006.

\section{Fysisch-chemisch grondonderzoek}

Bepaal de fosfaattoestand volgens de voorgeschreven methoden van grondonderzoek $\mathrm{P}-\mathrm{CaCl}_{2}$ en

$\mathrm{P}$-AL-getal. De analyseresultaten van grondonderzoek zijn:

- Uitslag P-CaCl 2 -getal: $\mathrm{mg} \mathrm{P} \mathrm{kg}^{-1}$

- Uitslag P-AL-getal: P-AL-getal in $\mathrm{mg}_{2} \mathrm{O}_{5}(100 \mathrm{~g})^{-1}$

\section{Toetsing}

Bereken grenswaarde:

Grenswaarde $\mathrm{P}-\mathrm{CaCl}_{2}$-getal $=$ Uitslag $\mathrm{P}-\mathrm{CaCl}_{2}$-getal $+\mathrm{z}_{1-\mathrm{a}} * \sqrt{ }\left(\mathrm{V}_{\text {tot } \mathrm{P}-\mathrm{CaCl} \text {-getal }}\right)\left(\mathrm{mg} \mathrm{P} \mathrm{kg}^{-1}\right)$

Grenswaarde P-AL-getal $=$ Uitslag P-AL-getal $+\mathrm{z}_{1-\mathrm{a}} * \sqrt{ }\left(\mathrm{V}_{\text {tot, }}\right.$-AL-getal $)\left(\mathrm{mg} \mathrm{P}_{2} \mathrm{O}_{5}(100 \mathrm{~g})^{-1}\right)$

Hierin is $z_{1-a}$ het $(1-a)$-percentiel van de standaard normaal verdeelde variabele, tot $v$ de variantie van de totale fout (steekproeffout + laboratoriumfout) in het geschatte perceelgemiddelde. 
De rekenregels worden gegeven in Bijlage 1 . Deze rekenregels dienen in het definitieve protocol te worden opgenomen.

NB 1 Er dient nog gekozen te worden voor de onbetrouwbaarheidsdrempel a (de kans dat ten onrechte wordt geconcludeerd dat de fosfaattoestand laag is): bijvoorbeeld $1 \%$ of $5 \%$.

NB 2 De toetsingsregels vragen nadere uitwerking en toelichting zodat derden ermee kunnen rekenen.

Vergelijk grenswaarde $\mathrm{P}-\mathrm{CaCl}_{2}$-getal met toetsingswaarde $\mathrm{P}-\mathrm{CaCl}_{2}$-getal (BP-CaCl $2-$ getal, $\mathrm{mg} \mathrm{P} / \mathrm{kg}$ ) en/of

Vergelijk grenswaarde P-AL-getal met toetsingswaarde P-AL-getal (CPAL mg $\mathrm{P}_{2} \mathrm{O}_{5}(100 \mathrm{~g})^{-1}$ )

\section{Registratie van de gegevens}

- Registreer de exacte locatie van het perceel op basis van de vormbepalende hoekpunten met behulp van de gps-data. Gebruik hiertoe zo nodig een topografische kaart met behulp van de Top-10 vectorkaart.

- Registreer in het (digitale) logboek het aantal steken dat werd genomen en maak een schema of tekening van de bemonsteringslocaties die werden gekozen of registreer de bemonsteringspunten die met gps zijn opgezocht.

- Registreer in het logboek de wijze waarop de monsters gecodeerd zijn.

- Registreer de waarnemingen die mogelijk van grote invloed kunnen zijn op de uitkomsten van het onderzoek.

\section{Literatuur}

Brus, D.J. \& L.E.E.M. Spätjens, 1997. Een nieuwe steekproefstrategie voor de inventarisatie van de fosfaattoestand van percelen; voorspelling van nauwkeurigheid en kosten. Wageningen, SC-DLO, 1997. Rapport 516.1, 49 blz.

Brus, D.J., L.E.E.M. Spätjens \& J.J. de Gruijter, 1999a. A sampling scheme for estimating the mean extractable phosphorus concentration of fields for environmental regulation. Geoderma 89, 1/2: 129-148.

Brus, D.J., W.J.M. te Riele \& J.J. de Gruijter, 1999b. Een nieuwe steekproefstrategie voor de inventarisatie van de fosfaattoestand van percelen; validatie van het nauwkeurigheidsmodel. Wageningen, SC-DLO. Rapport 516.2, 29 blz.

NEN 5704:1996. Bodem - Monstervoorbehandeling van grond - Extractie met een calciumchlorideoplossing $(0,01 \mathrm{~mol} / \mathrm{l})$. Nederlands Normalisatie Instituut, Delft.

NEN 5751 Bodem. Het voorbehandelen van grondmonsters voor fysisch-chemische analyses. Nederlands Normalisatie Instituut, Delft.

NEN 5793 Bodem. De bepaling van fosfaat in grond extraheerbaar met een ammoniumlactaatazijnzuur buffer (P-AL)'. Nederlands Normalisatie Instituut, Delft.

NPR 5741:2015 nl - Bodem - Richtlijn voor de keuze en toepassing van boortechnieken en monsternemingstoestellen voor grond, sediment, slib en grondwater bij milieuonderzoek.

ISO 11464:2006 en Bodem - Voorbehandeling van monsters voor fysisch-chemische analyses. Nederlands Normalisatie Instituut, Delft

NEN-ISO 15923-1:2013 en. Waterkwaliteit - Bepaling van de ionen met een discreet analysesysteem en spectrofotometrische detectie - Deel 1: Ammonium, chloride, nitraat, nitriet, ortho-fosfaat, silicaat en sulfaat). Nederlands Normalisatie Instituut, Delft.

Ehlert, P.A.I., Schoumans, O.F., Brus, D.J., Groot, W.J.M. de, Visschers, R. en Pleijters, M., 2005. Protocol voor het aanwijzen van gronden die in aanmerking komen voor een verhoogde gebruiksnorm voor fosfaat. Technische uitwerking.

Ehlert, P.A.I., D.J.J. Walvoort, P.C.J. van Vliet en O. Oenema, 2021 Vergelijking van twee bemonsteringsstrategieën bij toepassing van de gecombineerde indicator voor de fosfaattoestand van de bodem. Wageningen, Wageningen Environmental Research, Rapport 3080.

\subsection{W-methode}

Een protocol over de in-huis-methode van Eurofins Agro is niet beschikbaar in het publieke domein. 


\section{Literatuur}

Brus, D.J., L.E.E.M. Spätjens, J.J. de Gruijter, 1999. A sampling scheme for estimating the mean extractable phosphorus concentration of fields for environmental regulation. Geoderma 89: 129-148. https://doi.org/10.1016/S0016-7061(98)00123-2

Brus, D.J. W.J.M. te Riele \& J.J. Gruijter, 1999b. Een nieuwe steekproefstrategie voor de inventarisatie van de fosfaattoestand van percelen. Voorspelling van de nauwkeurigheid en kosten. Rapport 516.1. Staring Centrum (SC-DLO), Wageningen.

CBS, 2020. Fosfaatklasse per grondsoort, 2016-2019. https://www.cbs.nl/nl-nl/maatwerk/2020/24/fosfaatklasse-per-grondsoort-2016-2019.

Everitt, B.S. en A. Skrondal, 2010. The Cambridge Dictionary of Statistics 4th Edition. Cambridge University Press. ISBN: 9780521766999

Ehlert, P.A.I., Schoumans, O.F., Brus, D.J., Groot, W.J.M., Visschers, R. en Pleijter, 2005. Protocol voor het aanwijzen van gronden die in aanmerking komen voor een verhoogde gebruiksnorm. Technische uitwerking. Wageningen, Alterra, Alterra-rapport 1201. https://edepot.wur.nl/33711

Ferrari, Th.J. \& F.H.B. Vermeulen, 1955. Soil heterogeneity and soil testing testing Neth. J. Agric. Sci 3(4): 265-275.

Ferrari, Th.J. \& H.F.B. Vermeulen, 1956. De betrouwbaarheid van het grondonderzoek. In het bijzonder onder invloed van de ongelijkmatigheid van de grond. Het chemisch bodemvruchtbaarheidsonderzoek, 37-49.

Oenema, O., J.P. Mol-Dijkstra, J.C. Voogd, P.A.I. Ehlert en G.L. Velthof, 2016. Klassenindelingen voor de fosfaattoestand van de bodem, ten behoeve van de afleiding van fosfaatgebruiksnormen. Wageningen, Alterra Wageningen UR (University \& Research centre), Alterra-rapport 2743. https://library.wur.nl/WebQuery/wurpubs/fulltext/390048

Ris, J. \& J. Wolf, 1979. De bemonsteringsfout van de N-mineraal-bepaling op bouwland. Nota no. 64. Instituut voor Bodemvruchtbaarheid.

Termorshuizen, A., 2009. Comparing soil sampling schemes with special attention to the 'w-pattern' soil sampling scheme. Internal Report nr. 09-03. Blgg (opvraagbaar bij Eurofins Agro. B.V.).

Walvoort, D.J.J, D.J. Brus, J.J. de Gruijter, 2010. An R package for spatial coverage sampling and random sampling from compact geographical strata by k-means. Computers \& Geosciences 36 : 1261-1267. https://doi.org/10.1016/j.cageo.2010.04.005. 


\section{Bijlage 1 Berekening van het aantal steken}

Bij het berekenen van het benodigde aantal steken volgen we de methode van Brus, Spätjens, and de Gruijter (1999) en P. A. I. Ehlert et al. (2005).

Het vergroten van het aantal steken zal leiden tot een hogere precisie waarmee de fosfaattoestand kan worden vastgesteld. Dit zal echter ook leiden tot meer kosten. De precisie is de vierkantswortel van de totale variantie. Deze kan worden geschreven als:

$$
V_{\text {tot }}=V_{\text {veld }}+V_{\text {lab }}
$$

De totale variantie bestaat uit twee compomenten: de variantie van de steekproeffout $\left(V_{\text {veld }}\right)$ en de variantie van de laboratoriumfout $\left(V_{\text {lab }}\right)$. We volgen Ehlert $(2005$, p.88) door aan te nemen dat de standaardafwijking van de laboratoriumfout $\sigma_{\text {lab }}$ gelijk is aan 2.1. Bij $n$ steken per stratum geldt:

$$
V_{\mathrm{lab}}=\frac{\sigma_{\mathrm{lab}}^{2}}{n}
$$

Voor het steekproefontwerp van Brus, Spätjens, and de Gruijter (1999) (compacte evengrootte strata) kan de variantie van de steekproeffout worden voorspeld met:

$$
V_{\text {veld }}=\frac{1}{L^{2}} \sum_{\ell=1}^{L} \frac{\bar{\gamma}_{\ell}}{n_{\ell}}
$$

waarin $\bar{\gamma} \ell$ de gemiddelde semivariantie voor stratum $l$ en $n_{l}$ het aantal steken in stratum $\ell$ en $L$ het aantal strata.

Brus, Spätjens, and de Gruijter (1999) laten zien dat, door de compacte strata te beschouwen als vierkanten, de benaderingsfout zeer gering is. Het voordeel hiervan is dat we onafhankelijk van de vorm van het perceel uitspraken kunnen doen over de steekproeffout. Bovendien kan bovenstaande expressie worden vereenvoudigd doordat de strata dan identiek zijn:

$$
V_{\text {veld }}=\frac{1}{L^{2}} \sum_{\ell=1}^{L} \frac{\bar{\gamma}_{\ell}}{n_{\ell}}=\frac{\bar{\gamma}}{n L}
$$

waarin $n$ het aantal steken per stratum en $\bar{\gamma}$ de gemiddelde semivariantie voor een compact stratum dat wordt benaderd door een vierkant.

De variantie van de totale fout is dan gelijk aan

$$
V_{\text {tot }}=V_{\text {veld }}+V_{\text {lab }}=\frac{1}{n}\left(\frac{\bar{\gamma}}{L}+\sigma_{\text {lab }}^{2}\right)
$$




\section{Bijlage 2 Gelopen trajecten bij de W- methode}

Onderstaande kaartjes geven voor elk perceel de trajecten die gelopen zijn bij het bemonsteren volgens de W-methode. De kleur van een lijn correspondeert met een van de drie mengmonsters waarvoor de steken zijn genomen. De figuren zijn gebaseerd op de way-points en de meta-informatie die door Eurofins zijn aangeleverd. Niet voor elk perceel waren way-points beschikbaar. De kaarten zijn geanonimiseerd door een nieuwe oorsprong te kiezen in de linker beneden hoek. De assen zijn in meters t.o.v. die oorsprong.
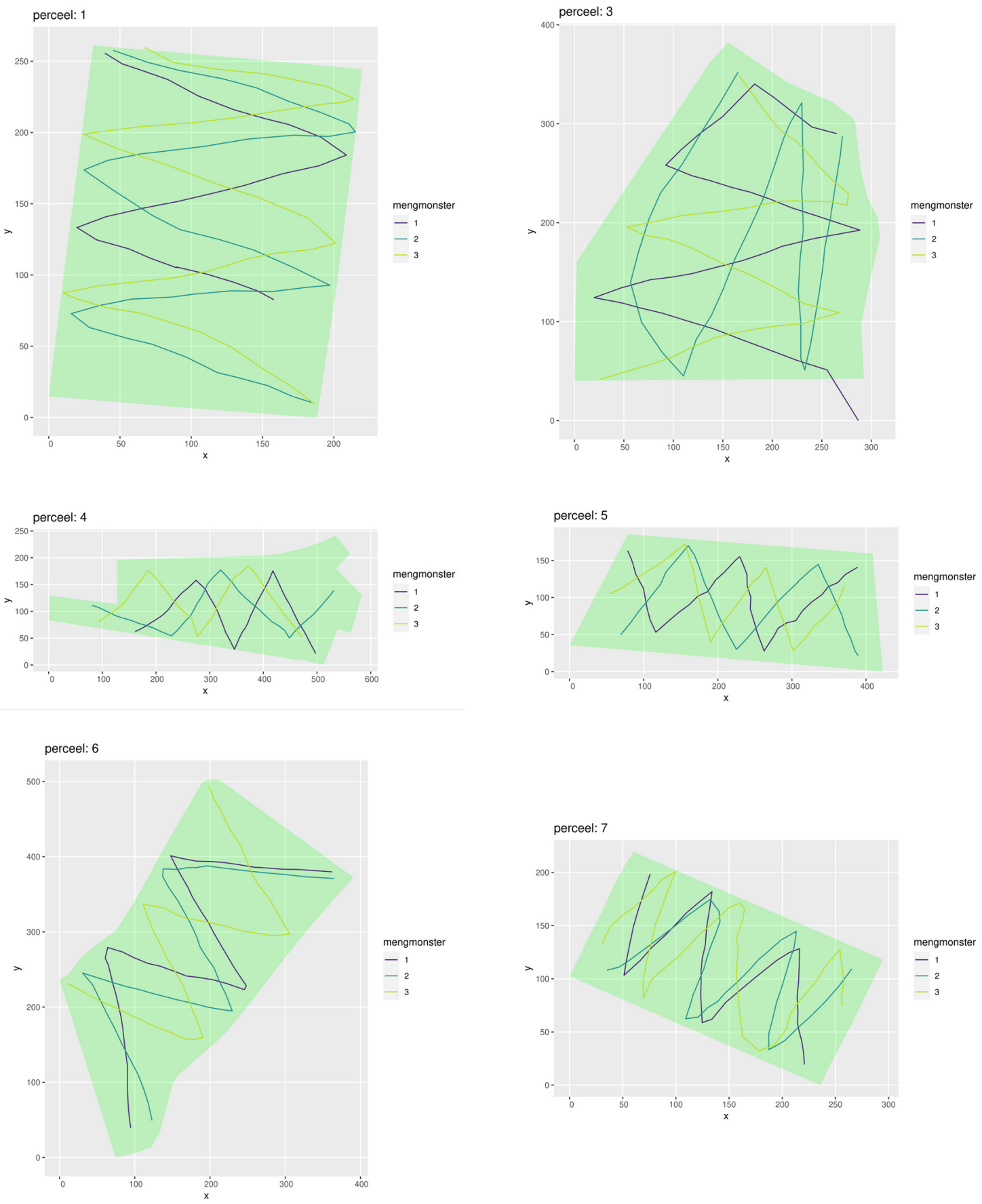

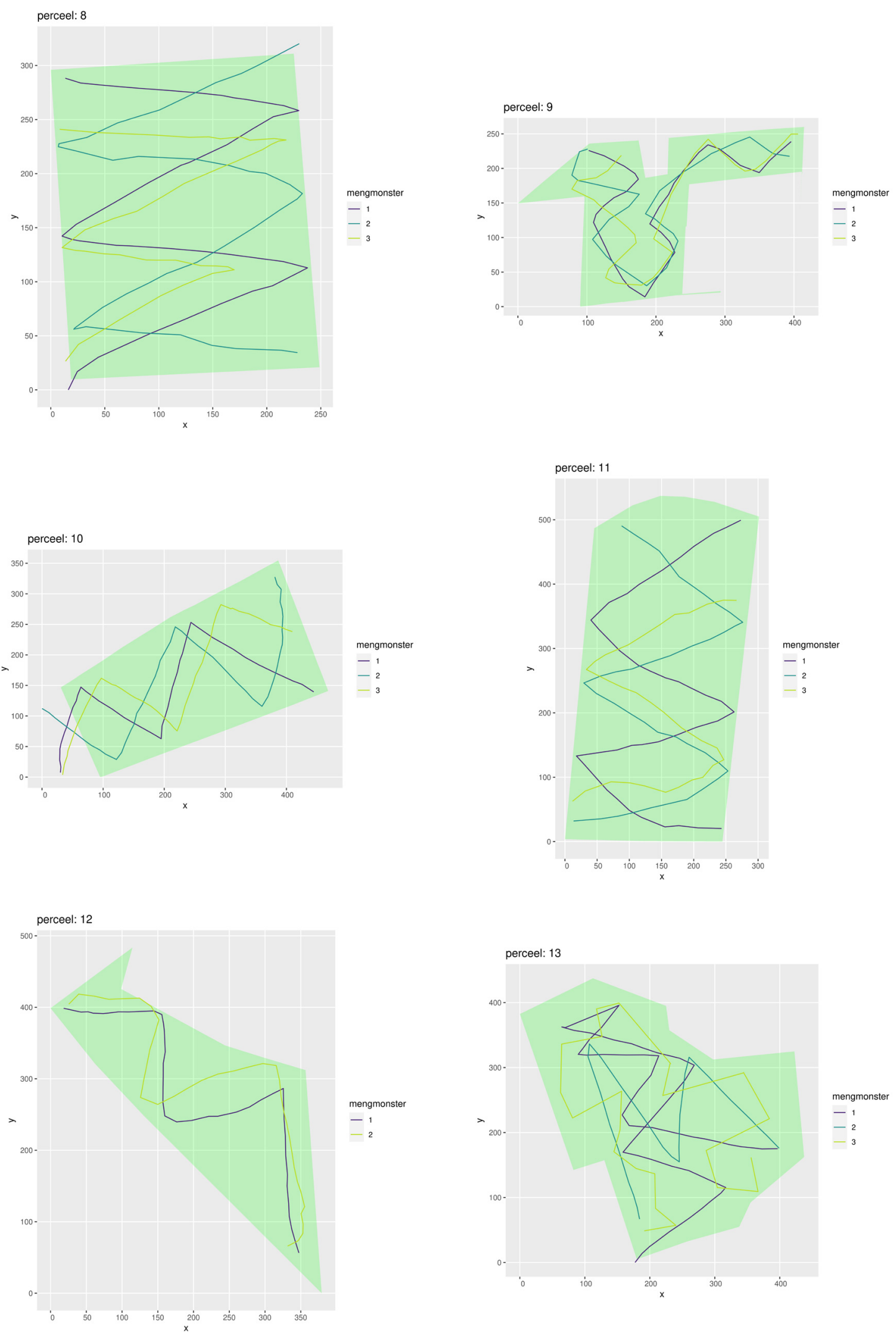

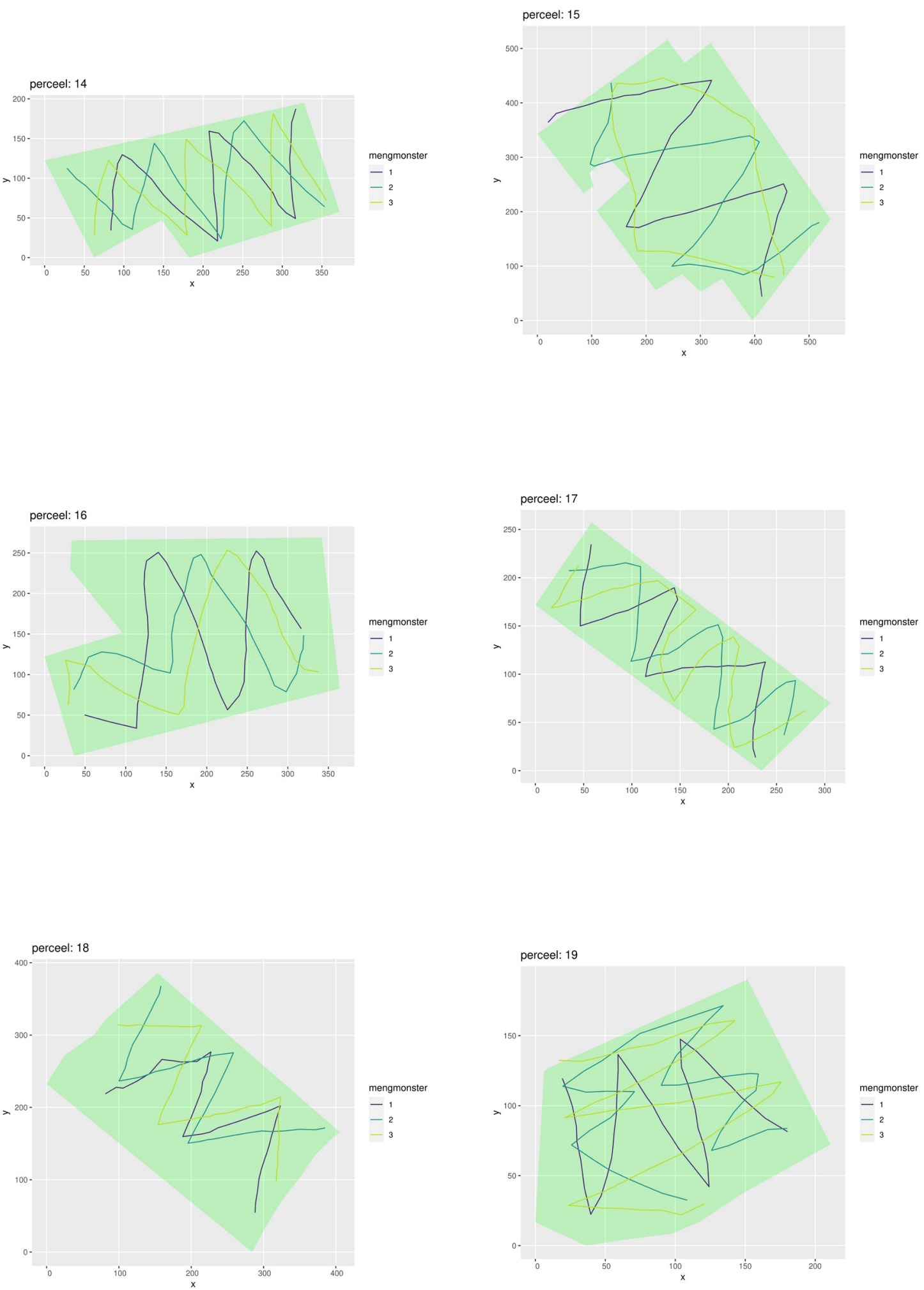

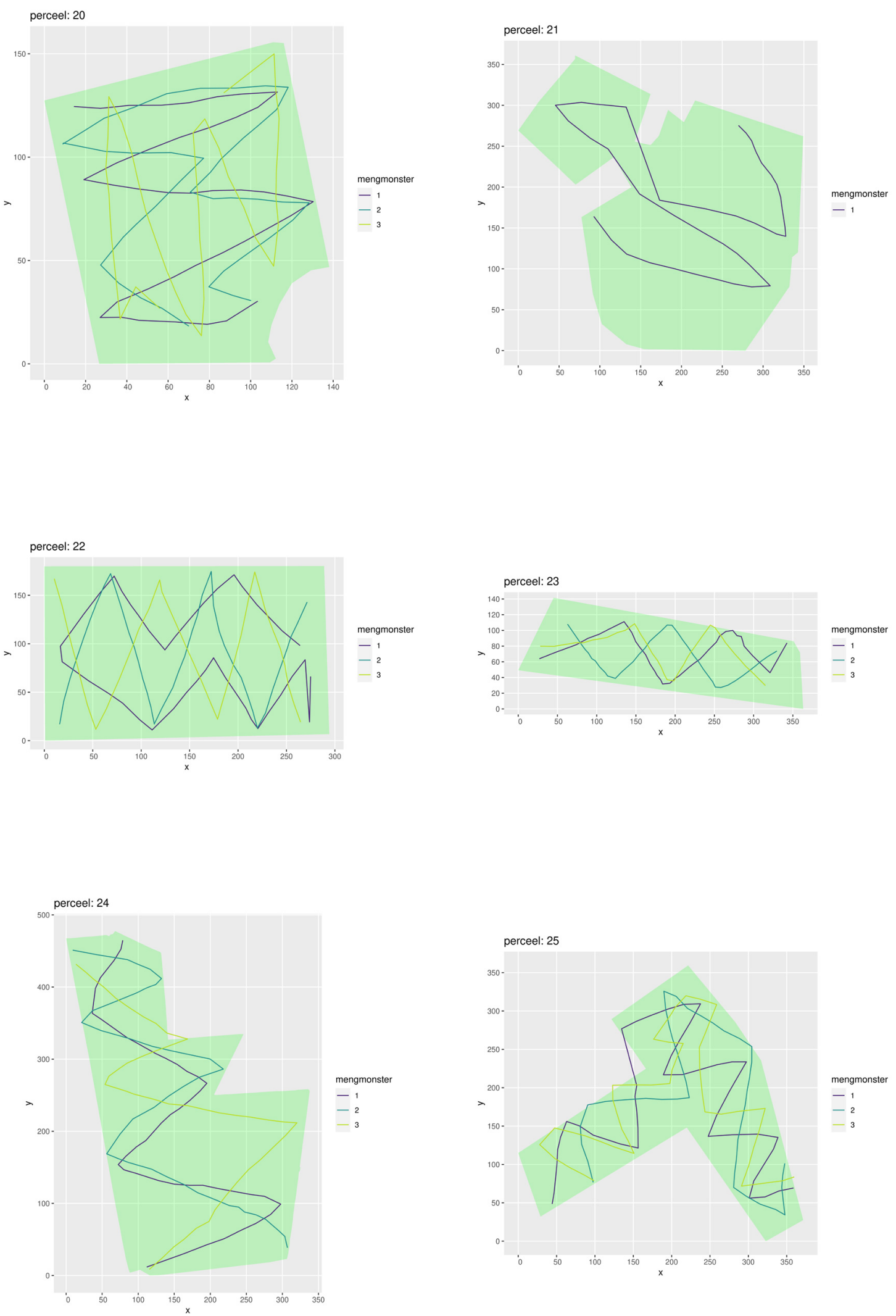

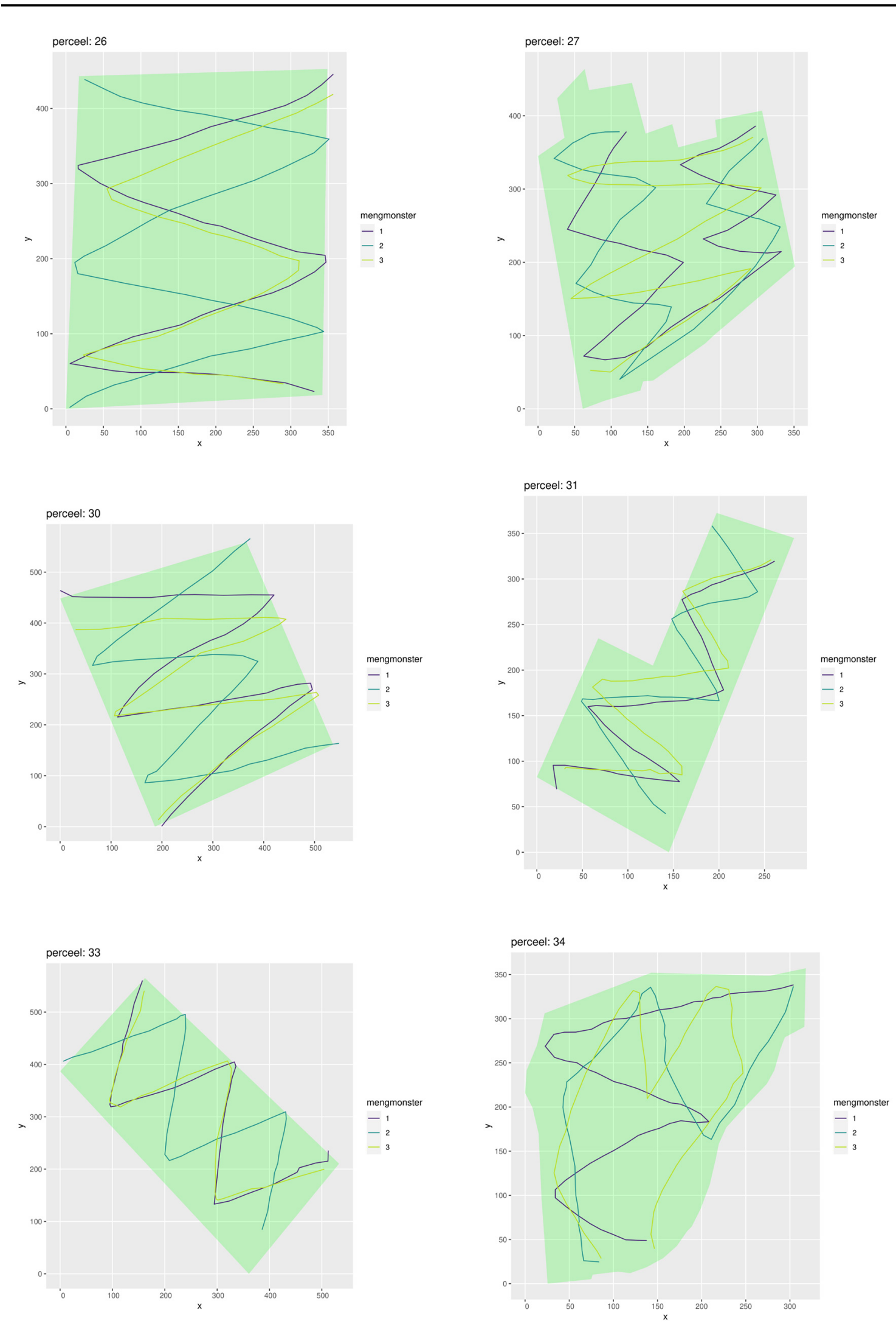

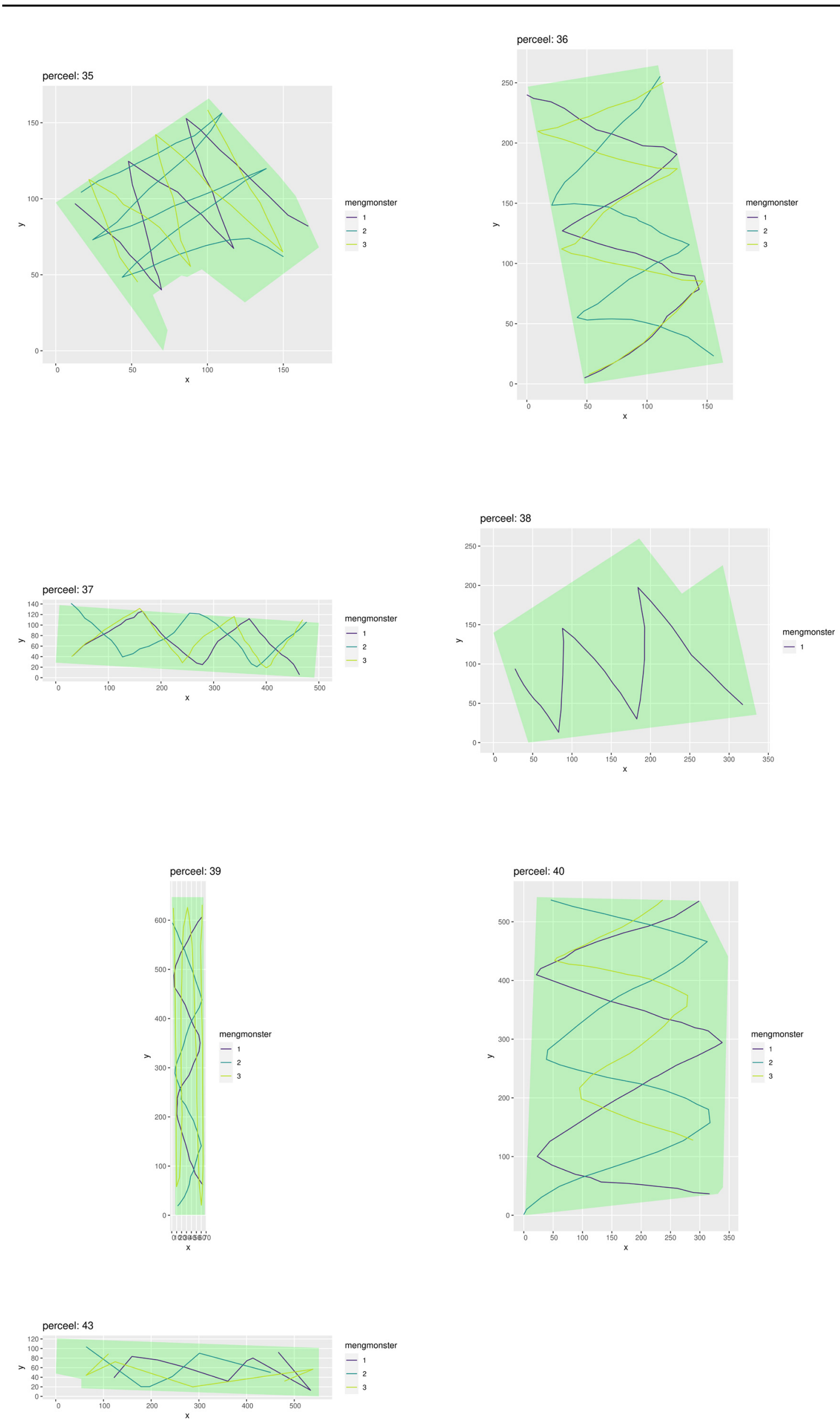


\section{Bijlage 3 Bubbelkaarten van de percelen voor het P-AL-getal}

De kaartjes in deze bijlage geven voor elk perceel het P-AL-getal ( $\mathrm{mg} \mathrm{P}_{2} \mathrm{O}_{5} / 100 \mathrm{~g}$ ) op de locaties van de afzonderlijke steken. De kaartjes geven een indruk van de ruimtelijke variatie van het P-AL-getal. De kaarten zijn geanonimiseerd door een nieuwe oorsprong te kiezen in de linker beneden hoek. De assen zijn in meters t.o.v. die oorsprong.
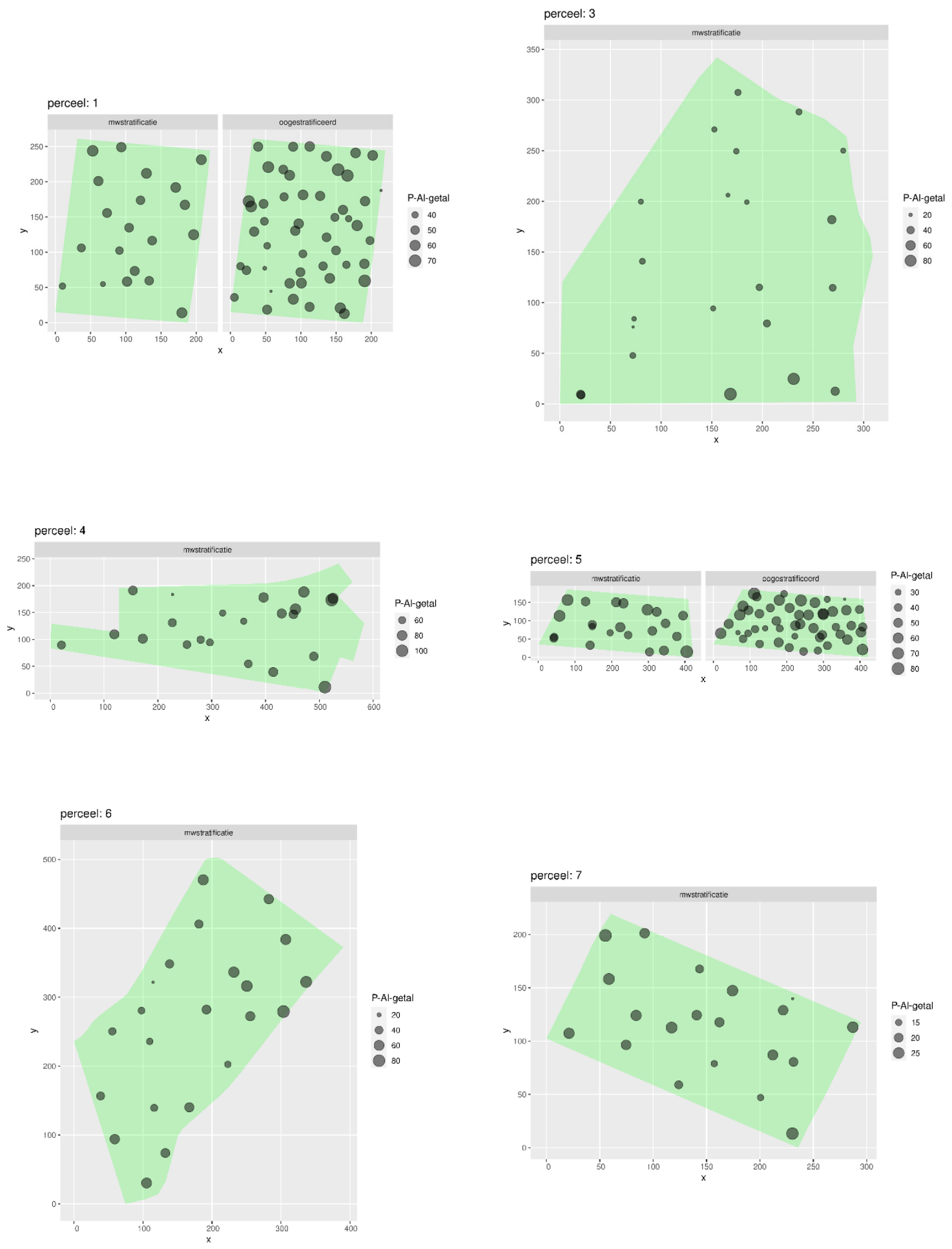

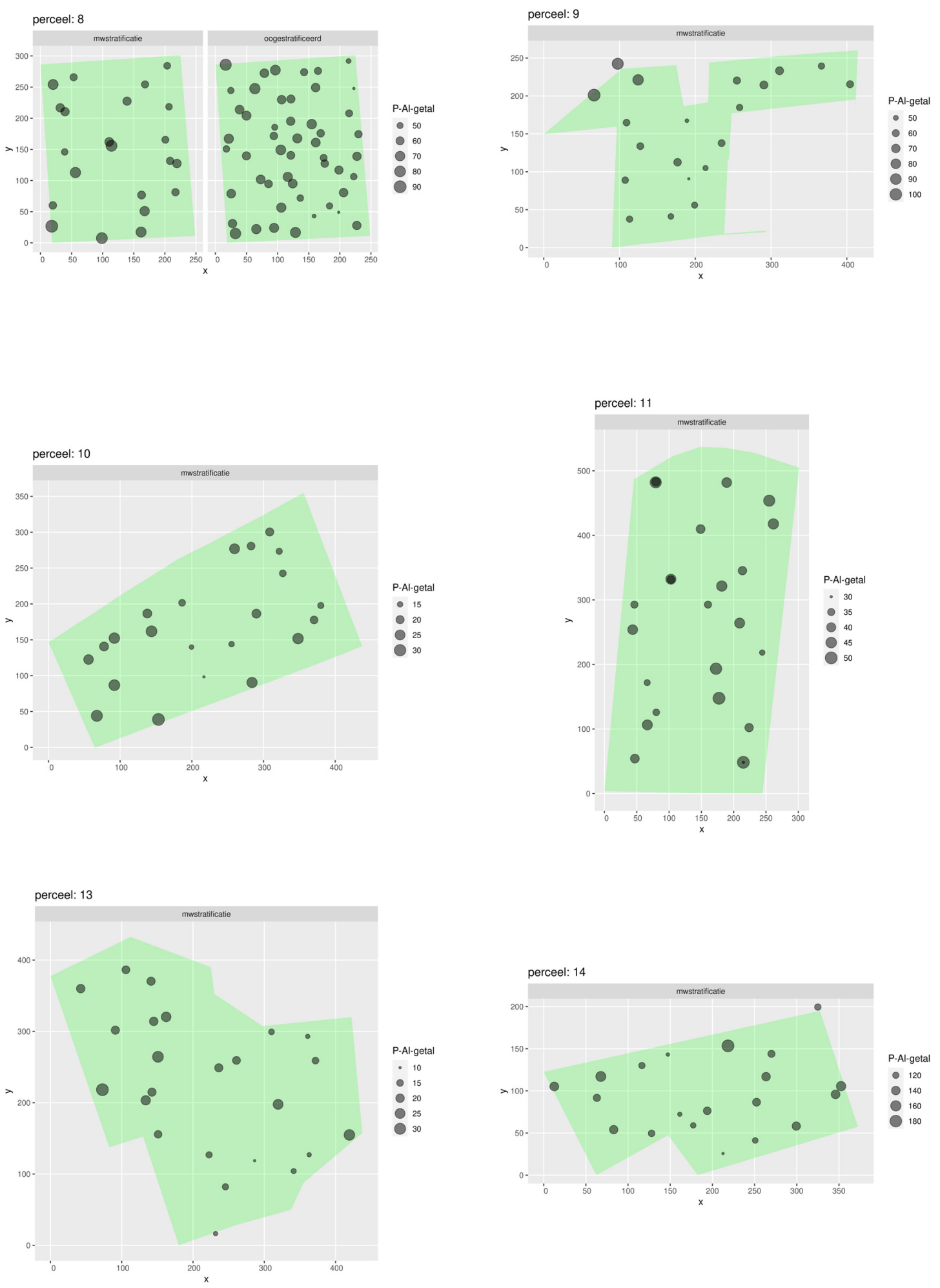

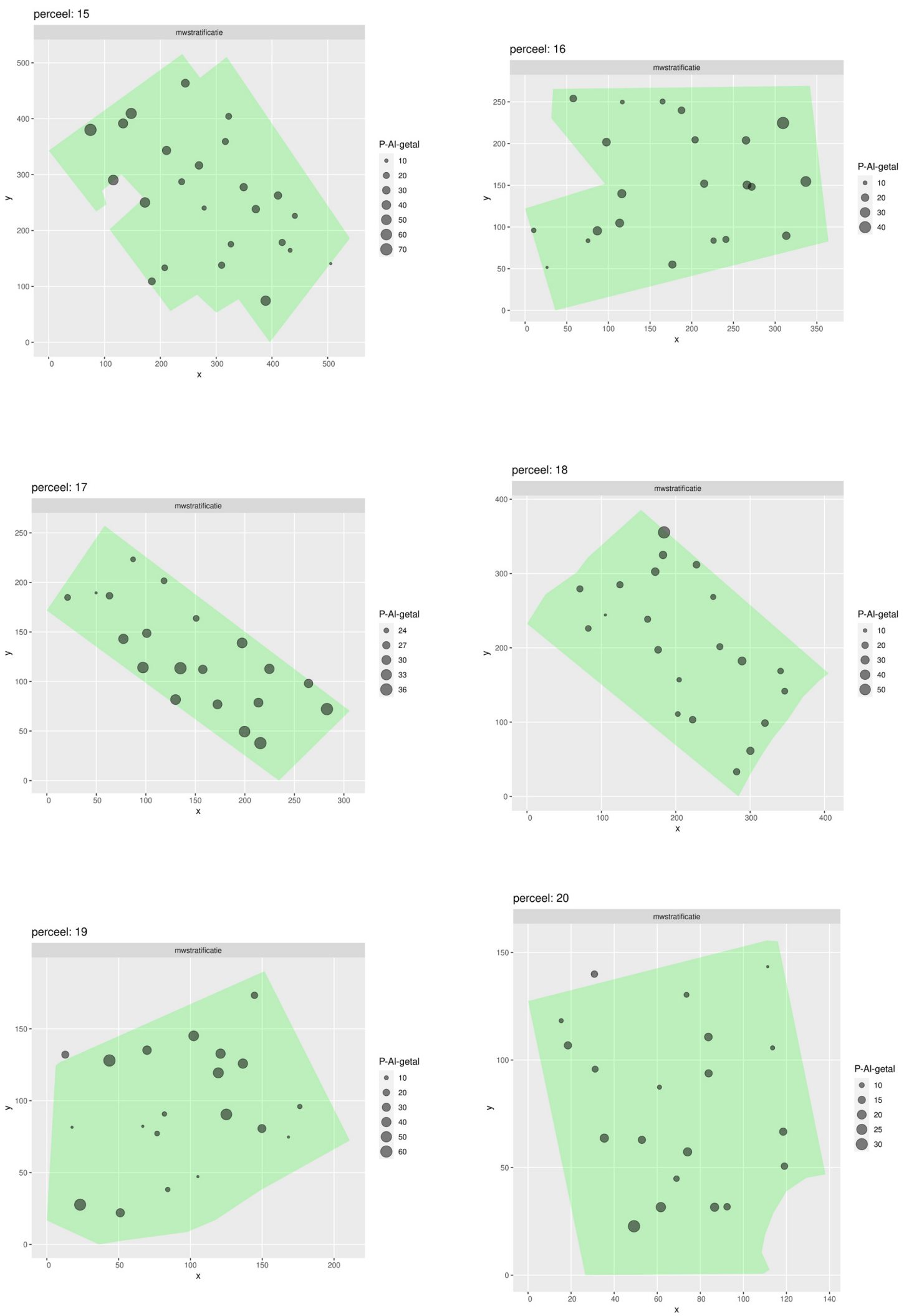

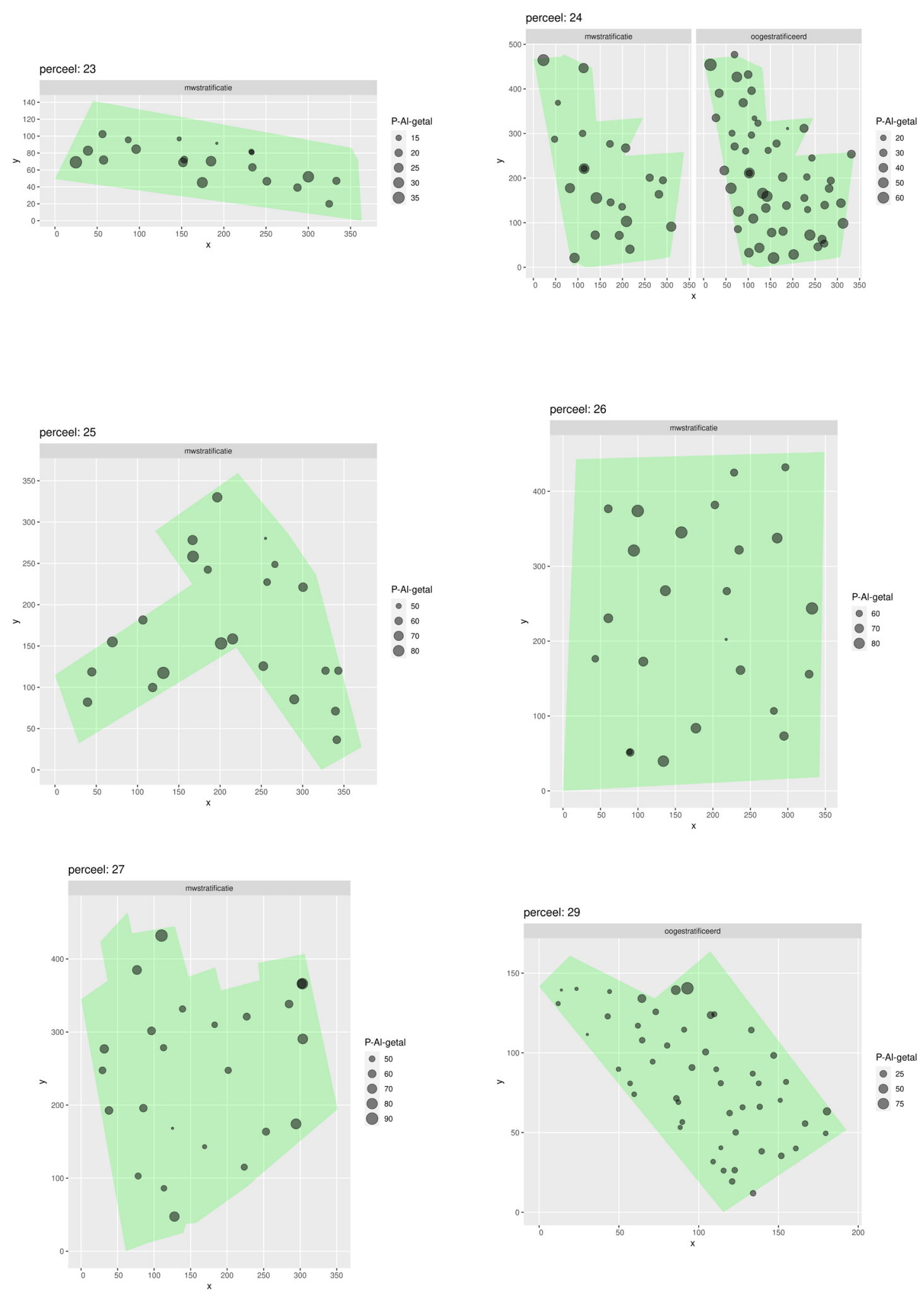

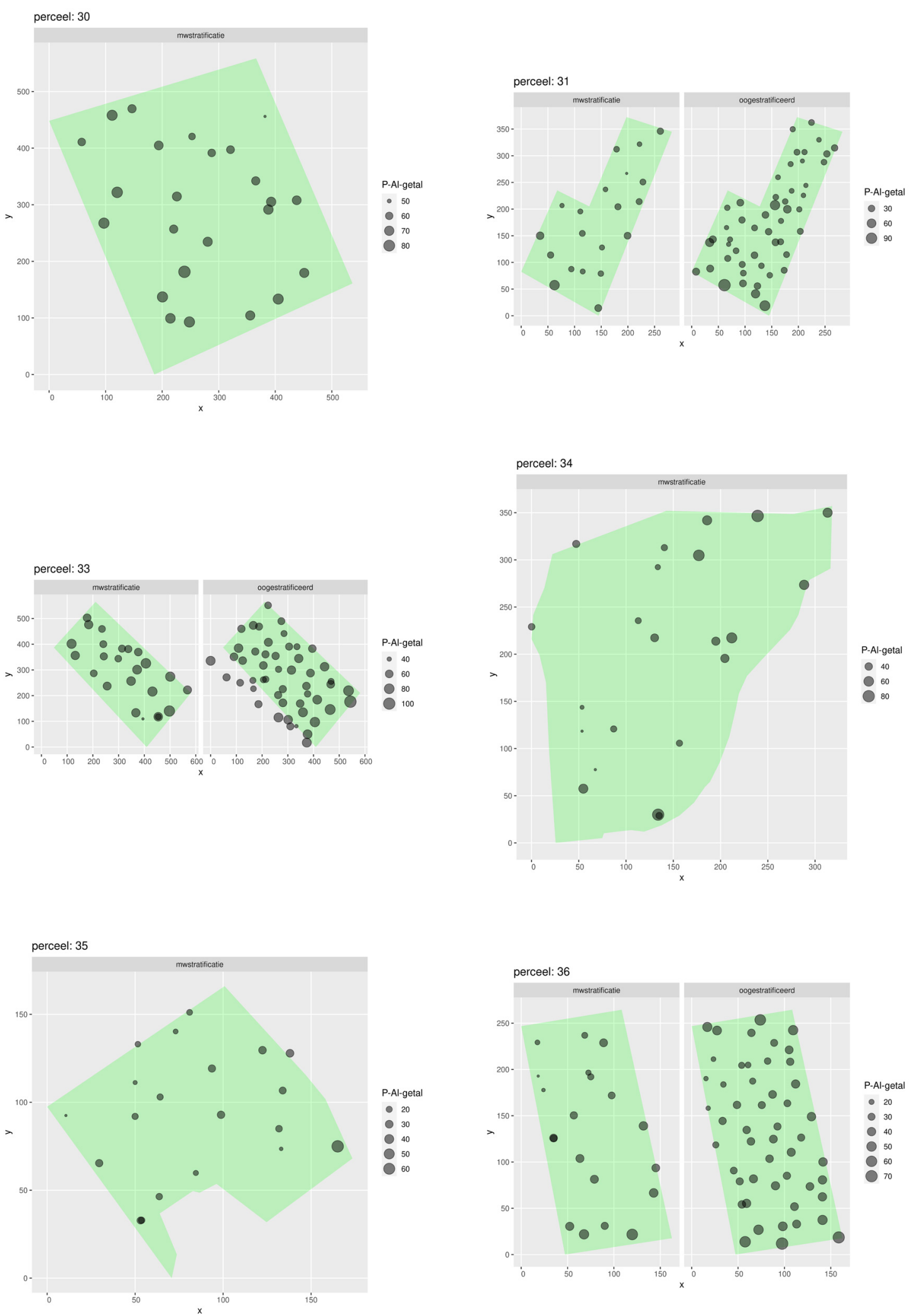

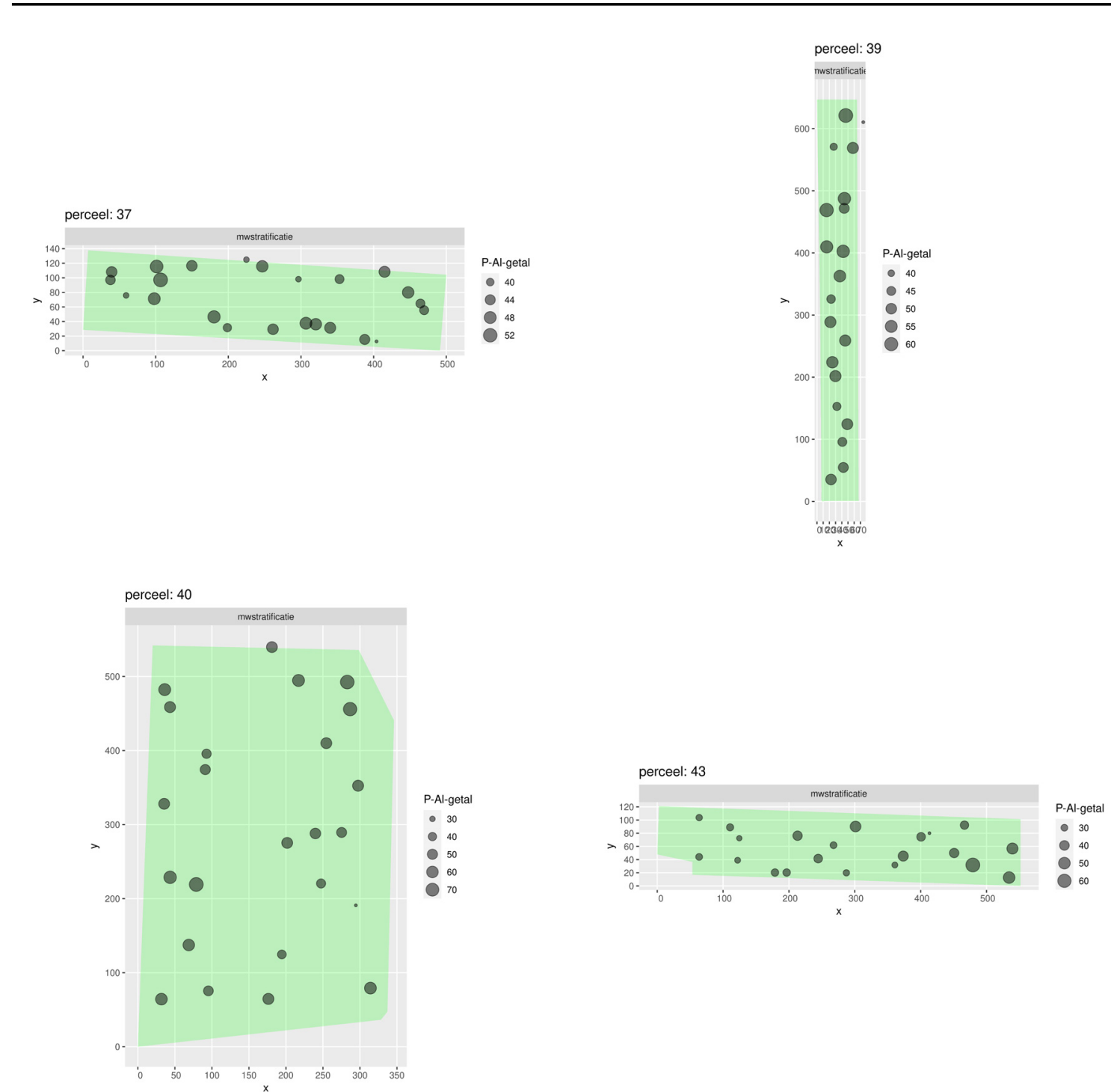


\section{Bijlage 4 Bubbelkaarten van de percelen voor het $\mathrm{P}-\mathrm{CaCl}_{2}$-getal}

De kaartjes in deze bijlage geven voor elk perceel het $\mathrm{P}-\mathrm{CaCl}_{2}$-getal $(\mathrm{mg} \mathrm{P} / \mathrm{kg})$ op de locaties van de afzonderlijke steken. De kaartjes geven een indruk van de ruimtelijke variatie van het $\mathrm{P}-\mathrm{CaCl}_{2}$-getal. De kaarten zijn geanonimiseerd door een nieuwe oorsprong te kiezen in de linker beneden hoek. De assen zijn in meters t.o.v. die oorsprong.
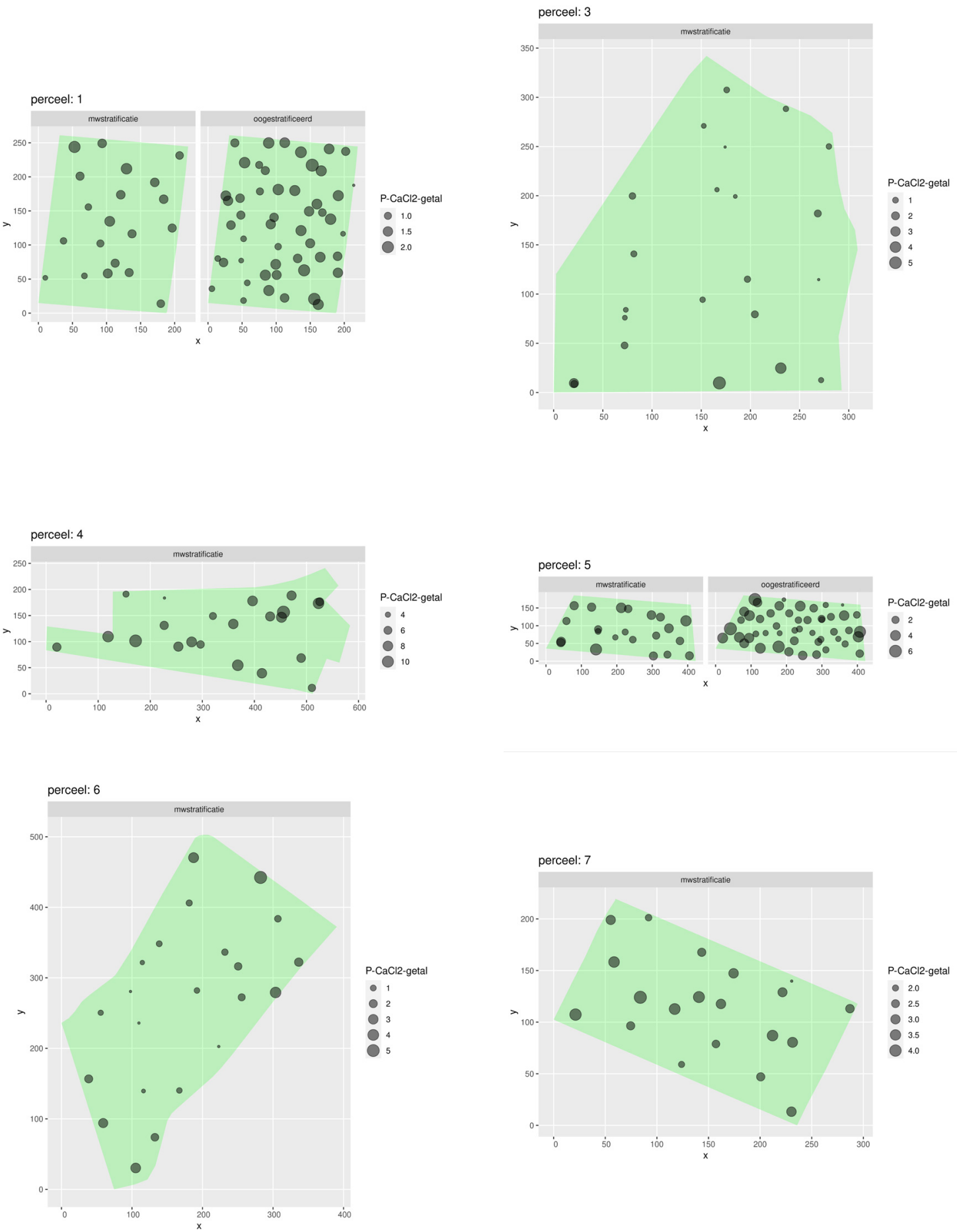

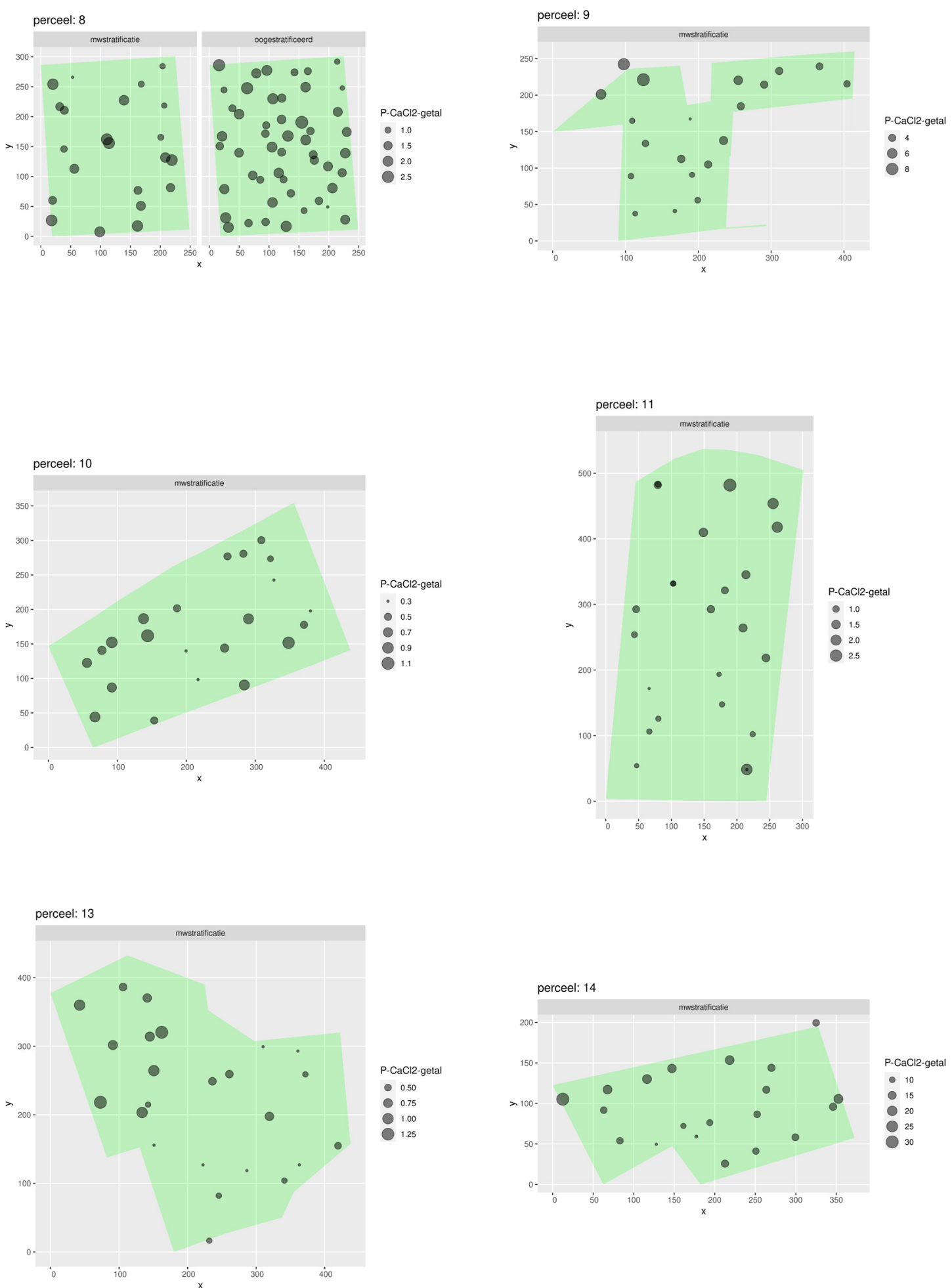

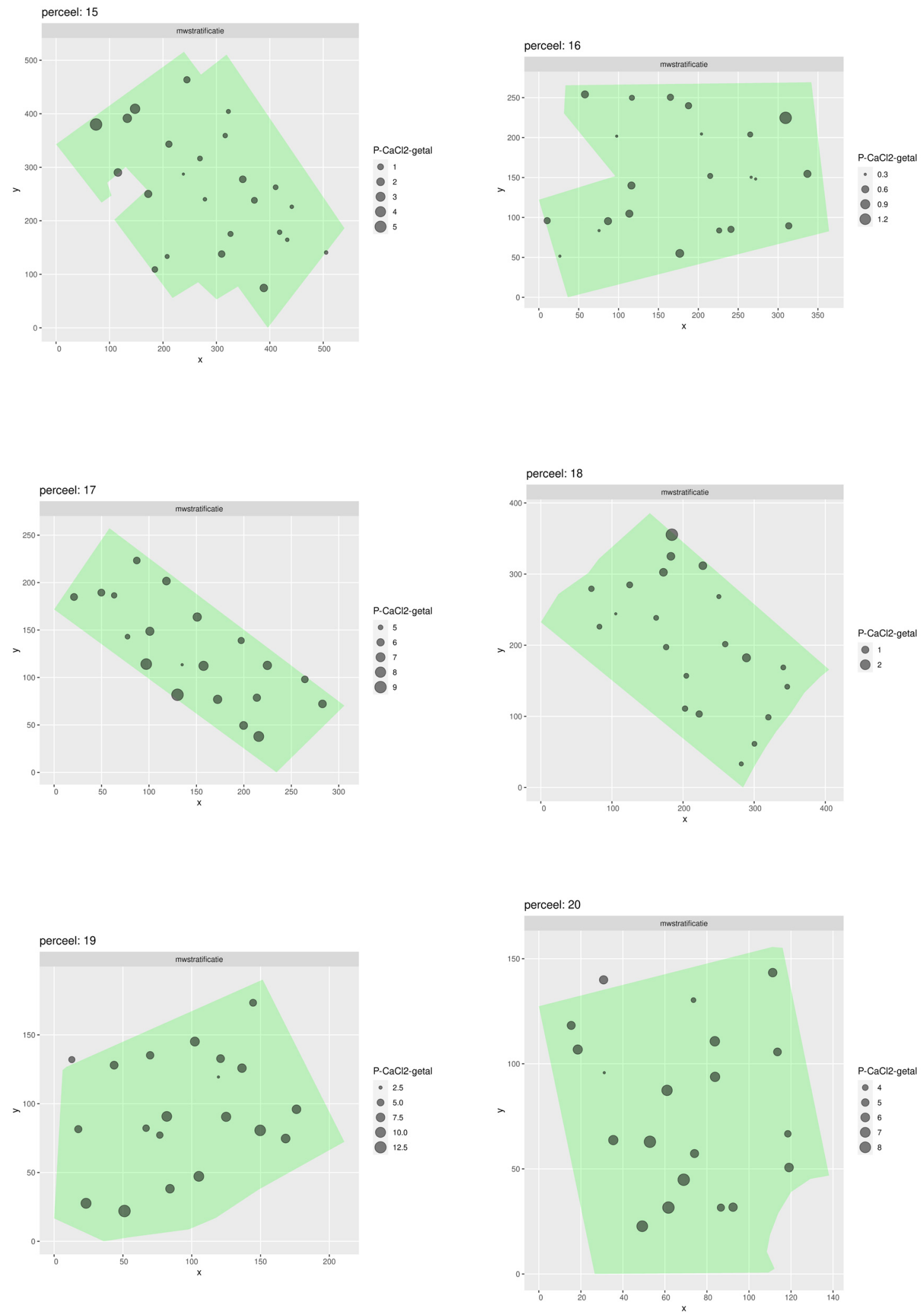

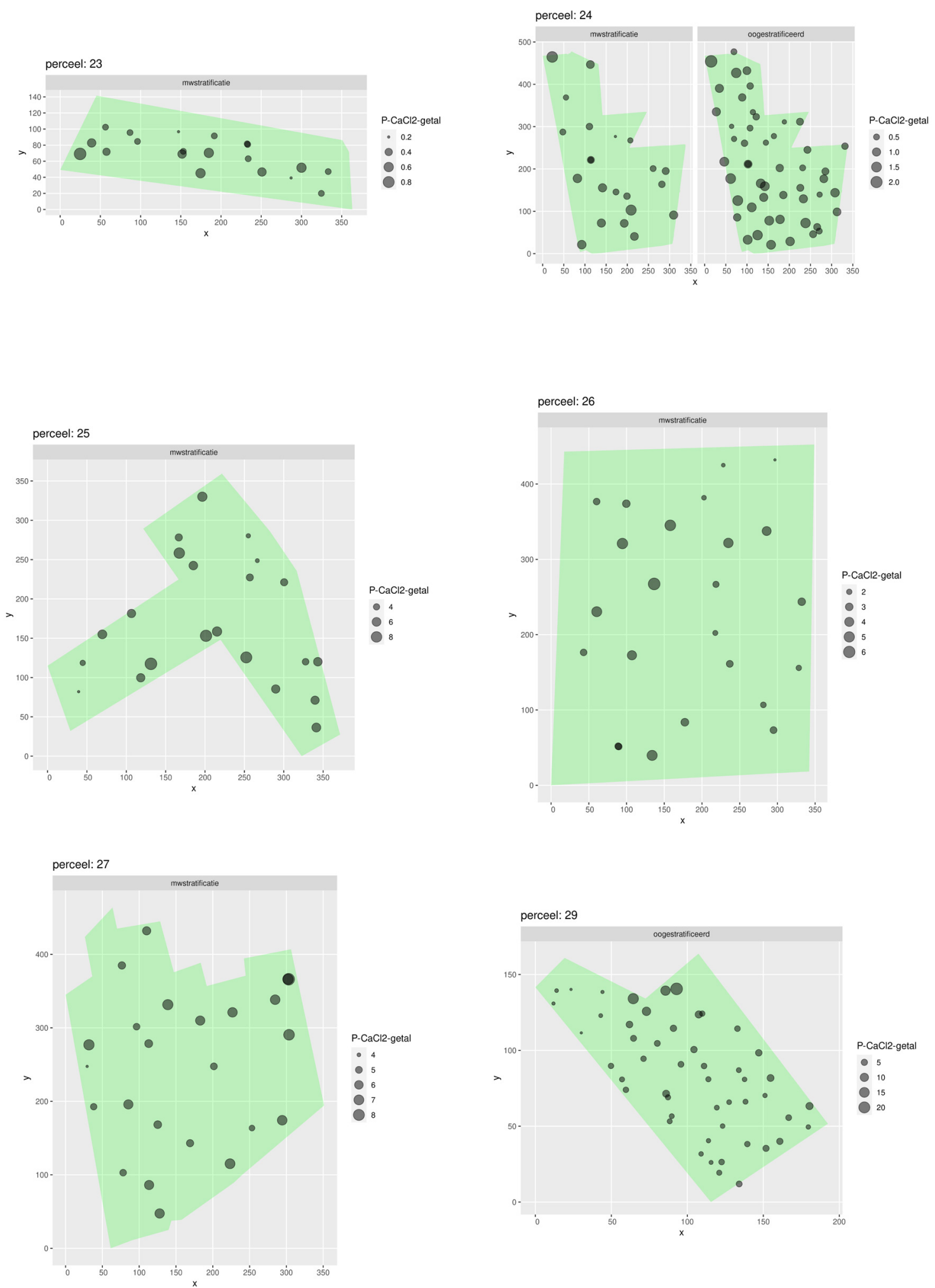

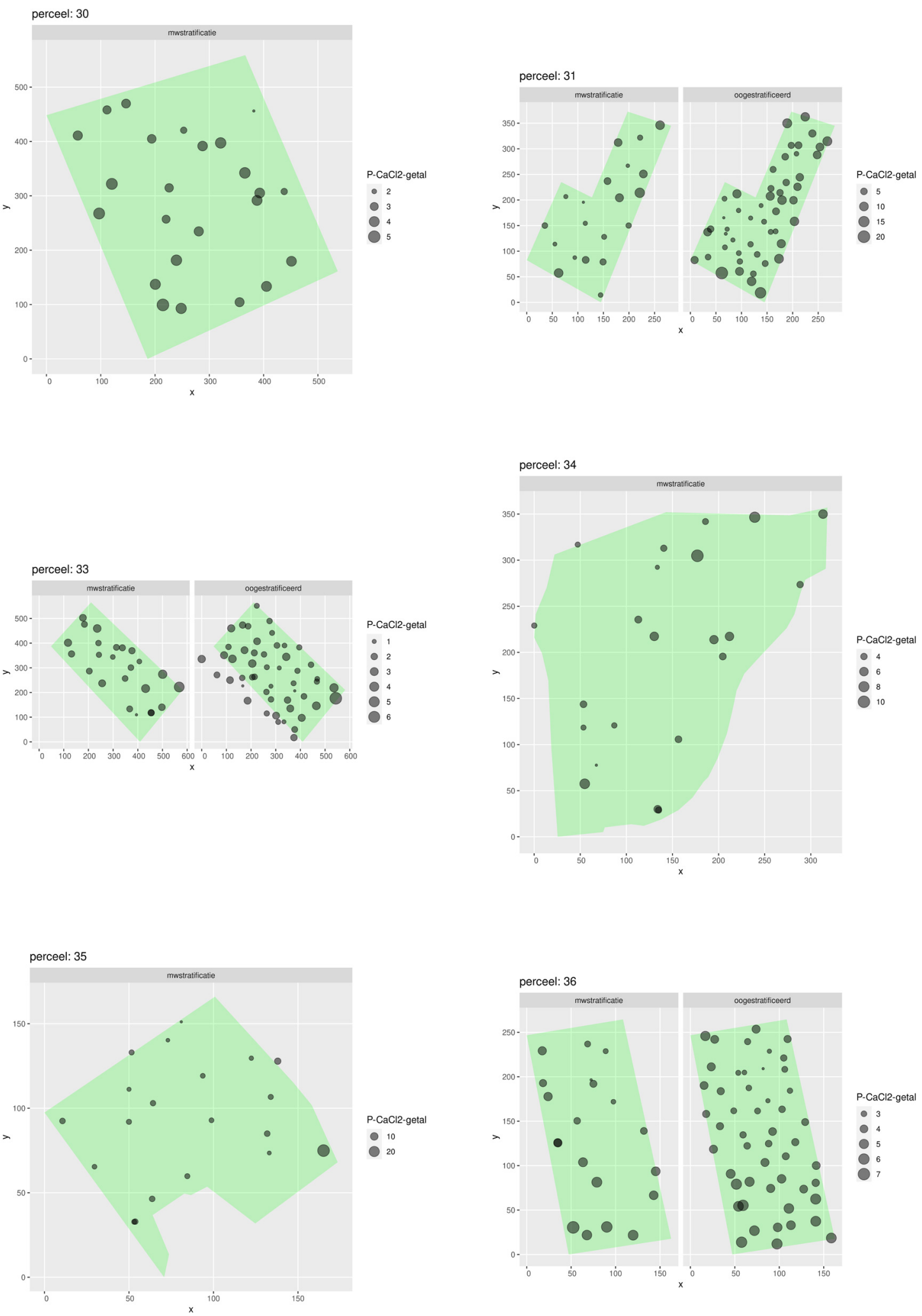

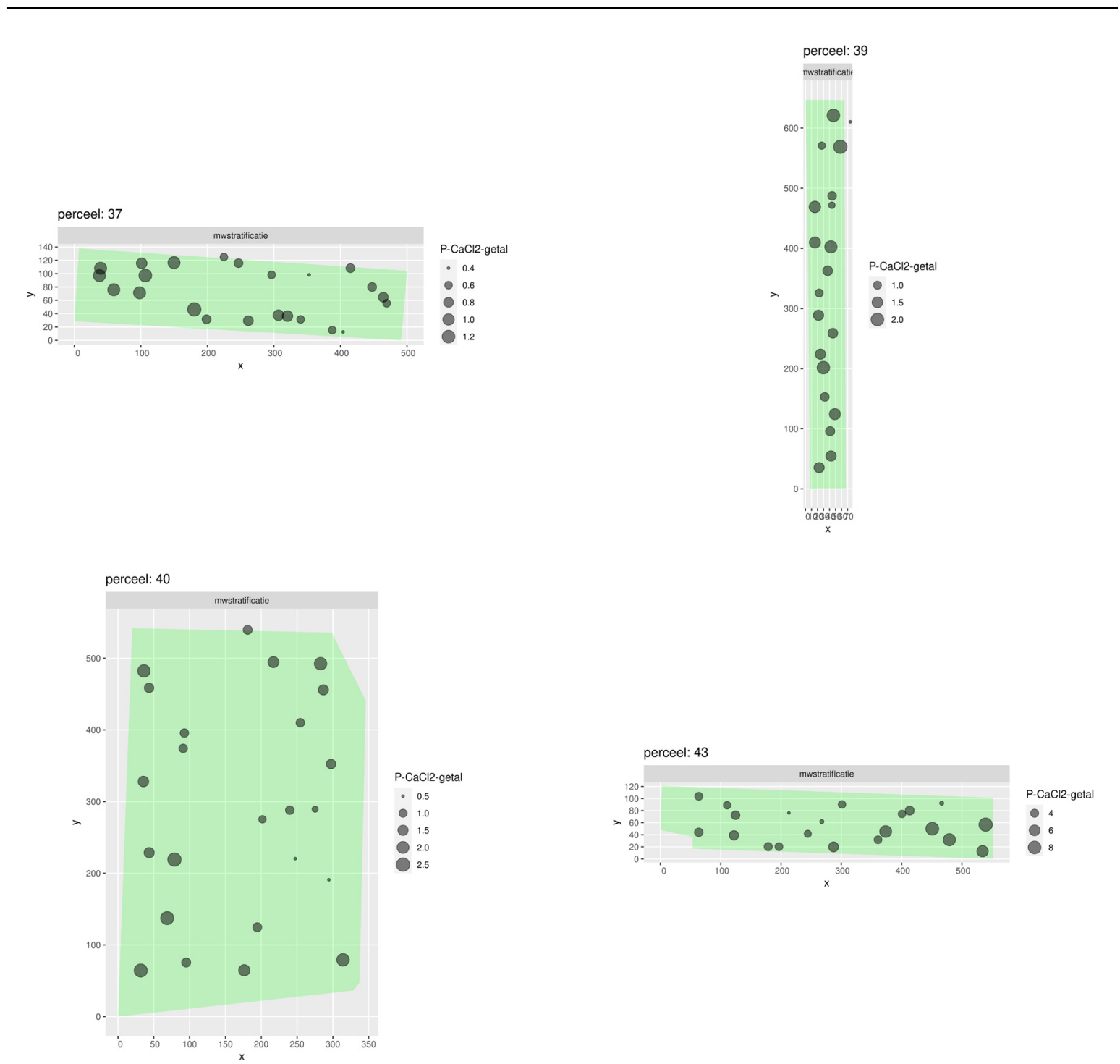


\section{Bijlage 5 Nauwkeurigheid}

De mean squared error (MSE) is een maat voor de nauwkeurigheid. De MSE is gelijk aan de som van de gekwadrateerde gemiddelde fout en de variantie van de fout. Hier wordt vaak de wortel van genomen (RMSE), zodat de eenheid gelijk is aan die van de doelvariabele.

We beginnen met het schatten van het mengmonstergemiddelde voor elk perceel $i(i=1 \ldots 43)$ voor zowel de gestratificeerde aselecte steekproef:

$$
\bar{y}_{\mathrm{s} i}=\frac{1}{n} \sum_{j=1}^{n} y_{\mathrm{s} i j}
$$

als de W-methode:

$$
\bar{y}_{\mathrm{w} i}=\frac{1}{n} \sum_{j=1}^{n} y_{\mathrm{w} i j}
$$

waarin $y_{\mathrm{s} i j}$ en $y_{\mathrm{w} i j}$ de $j$ de mengmonsterbepaling is voor perceel $i$ voor respectievelijk de gestratificeerde aselecte steekproef (s) en de W-methode (w). In ons geval is $n=3$ omdat we beschikken over drie herhalingen per perceel. $\bar{y}_{\mathrm{s} i}$ is unbiased, $\bar{y}_{\mathrm{w} i}$ niet.

De MSE voor perceel $i$ is voor respectievelijk de gestratificeerde steekproef en de w-methode gelijk aan:

$$
\begin{gathered}
\mathrm{MSE}_{\mathrm{s} i}=\left(\bar{y}_{\mathrm{s} i}-\bar{y}_{\mathrm{s} i}\right)^{2}+\frac{1}{n-1} \sum_{j=1}^{n}\left(y_{\mathrm{s} i j}-\bar{y}_{\mathrm{s} i}\right)^{2}=\frac{1}{n-1} \sum_{j=1}^{n}\left(y_{\mathrm{s} i j}-\bar{y}_{\mathrm{s} i}\right)^{2} \\
\mathrm{MSE}_{\mathrm{w} i}=\left(\bar{y}_{\mathrm{w} i}-\bar{y}_{\mathrm{s} i}\right)^{2}+\frac{1}{n-1} \sum_{j=1}^{n}\left(y_{\mathrm{w} i j}-\bar{y}_{\mathrm{w} i}\right)^{2}
\end{gathered}
$$


Wageningen Environmental Research Postbus 47

6700 AA Wageningen

T 0317480700

www.wur.nl/environmental-research

Wageningen Environmental Research Rapport 3080

ISSN 1566-7197
De missie van Wageningen University \& Research is 'To explore the potential of nature to improve the quality of life'. Binnen Wageningen University \& Research bundelen Wageningen University en gespecialiseerde onderzoeksinstituten van Stichting Wageningen Research hun krachten om bij te dragen aan de oplossing van belangrijke vragen in het domein van gezonde voeding en leefomgeving. Met ongeveer 30 vestigingen, 6.500 medewerkers ( $5.500 \mathrm{fte}$ ) en 12.500 studenten behoort Wageningen University \& Research wereldwijd tot de aansprekende kennisinstellingen binnen haar domein. De integrale benadering van de vraagstukken en de samenwerking tussen verschillende disciplines vormen het hart van de unieke Wageningen aanpak. 


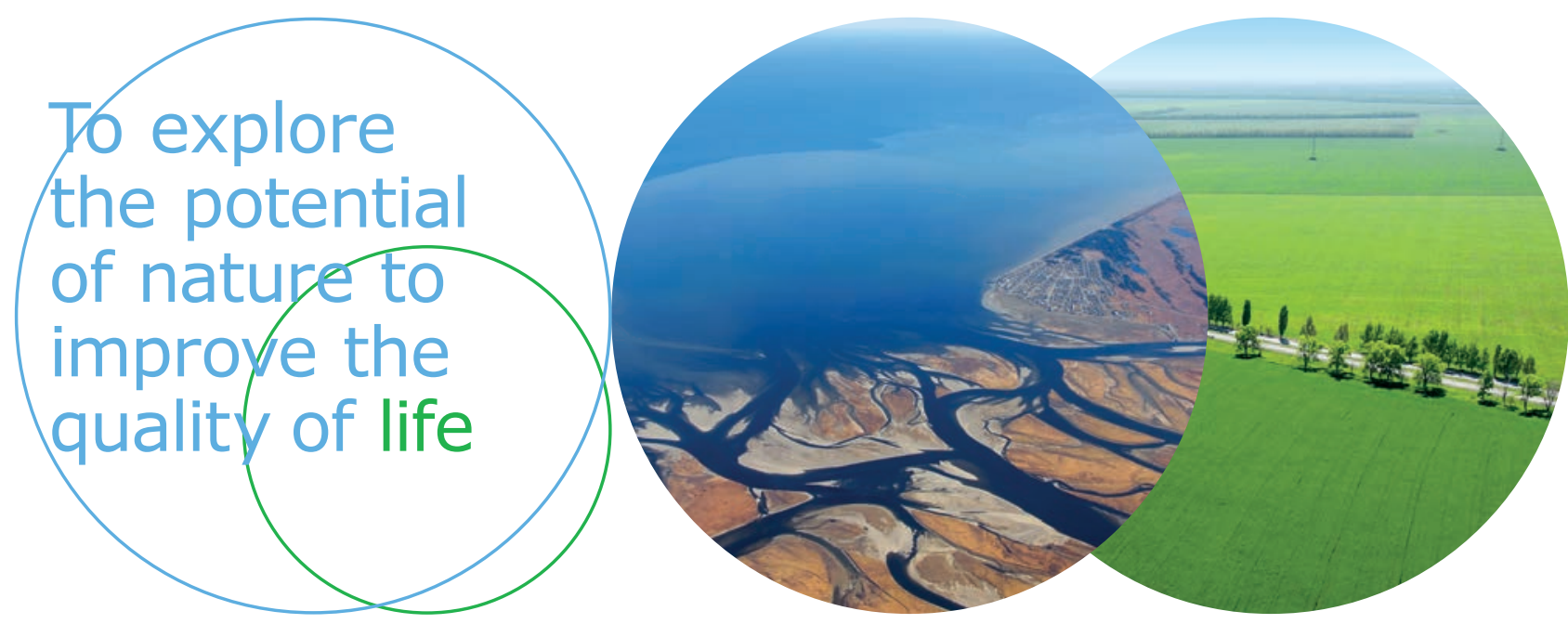

Wageningen Environmental Research Postbus 47

$6700 \mathrm{AB}$ Wageningen

T 317480700

www.wur.nl/environmental-research

Rapport 3080

ISSN 1566-7197
De missie van Wageningen University \& Research is 'To explore the potential of nature to improve the quality of life'. Binnen Wageningen University \& Research bundelen Wageningen University en gespecialiseerde onderzoeksinstituten van Stichting Wageningen Research hun krachten om bij te dragen aan de oplossing van belangrijke vragen in het domein van gezonde voeding en leefomgeving. Met ongeveer 30 vestigingen, 6.500 medewerkers ( $5.000 \mathrm{fte}$ ) en 12.500 studenten behoort Wageningen University \& Research wereldwijd tot de aansprekende kennisinstellingen binnen haar domein. De integrale benadering van de vraagstukken en de samenwerking tussen verschillende disciplines vormen het hart van de unieke Wageningen aanpak. 